HEXACHLOROBENZENE

(CASRN 118-74-1)

AdMINISTERED by GAVAGE

to Female Sprague DaWley

(HSD:Sprague DaWleY ${ }^{\circledR}$ SD $^{\circledR}$ )

RATS

NTP TOX 77

MARCH 2021 


\section{NTP Technical Report on the Toxicity Studies of Hexachlorobenzene (CASRN 118-74-1) Administered by Gavage to Female Sprague Dawley (Hsd:Sprague Dawley ${ }^{\circledR}$ SD $^{\circledR}$ ) Rats}

Toxicity Report 77

March 2021

National Toxicology Program

Public Health Service

U.S. Department of Health and Human Services

ISSN: 2378-8992

Research Triangle Park, North Carolina, USA 


\section{Foreword}

The National Toxicology Program (NTP), established in 1978, is an interagency program within the Public Health Service of the U.S. Department of Health and Human Services. Its activities are executed through a partnership of the National Institute for Occupational Safety and Health (part of the Centers for Disease Control and Prevention), the Food and Drug Administration (primarily at the National Center for Toxicological Research), and the National Institute of Environmental Health Sciences (part of the National Institutes of Health), where the program is administratively located. NTP offers a unique venue for the testing, research, and analysis of agents of concern to identify toxic and biological effects, provide information that strengthens the science base, and inform decisions by health regulatory and research agencies to safeguard public health. NTP also works to develop and apply new and improved methods and approaches that advance toxicology and better assess health effects from environmental exposures.

The Toxicity Report series began in 1991. The studies described in the NTP Toxicity Report series are designed and conducted to characterize and evaluate the toxicological potential of selected substances in laboratory animals (usually two species, rats and mice). Substances (e.g., chemicals, physical agents, and mixtures) selected for NTP toxicity studies are chosen primarily on the basis of human exposure, level of commercial production, and chemical structure. The interpretive conclusions presented in the Toxicity Reports are derived solely from the results of these NTP studies, and extrapolation of these results to other species, including characterization of hazards and risks to humans, requires analyses beyond the intent of these reports. Selection for study per se is not an indicator of a substance's toxic potential.

NTP conducts its studies in compliance with its laboratory health and safety guidelines and Food and Drug Administration Good Laboratory Practice Regulations and meets or exceeds all applicable federal, state, and local health and safety regulations. Animal care and use are in accordance with the Public Health Service Policy on Humane Care and Use of Laboratory Animals. Studies are subjected to retrospective quality assurance audits before they are presented for public review. Draft reports undergo external peer review before they are finalized and published.

The NTP Toxicity Reports are available free of charge on the NTP website and cataloged in PubMed, a free resource developed and maintained by the National Library of Medicine (part of the National Institutes of Health). Data for these studies are included in NTP's $\underline{\text { Chemical Effects }}$ in Biological Systems database.

For questions about the reports and studies, please email NTP or call 984-287-3211. 


\section{Table of Contents}

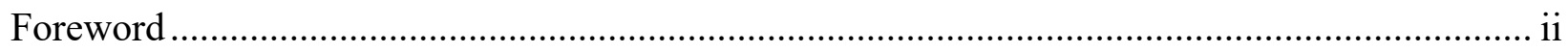

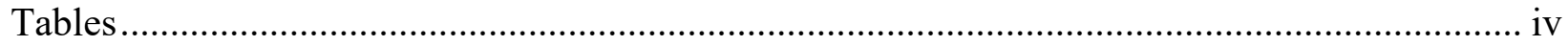

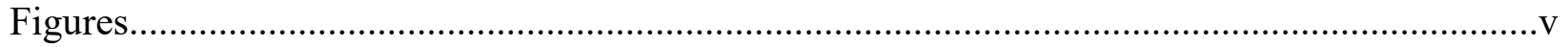

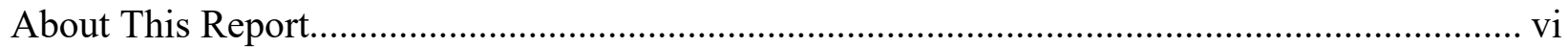

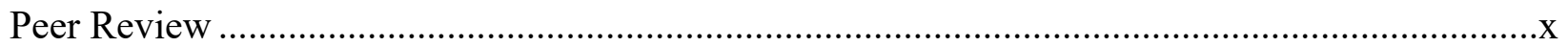

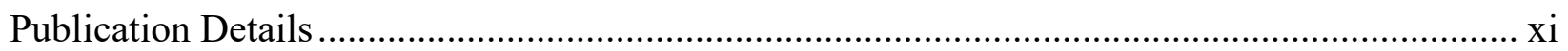

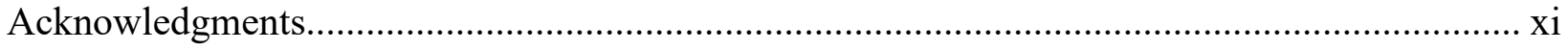

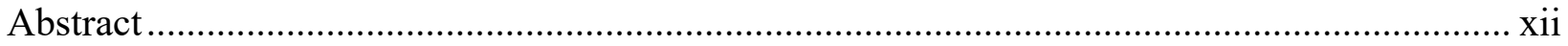

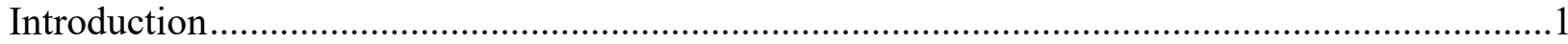

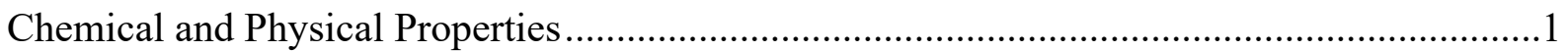

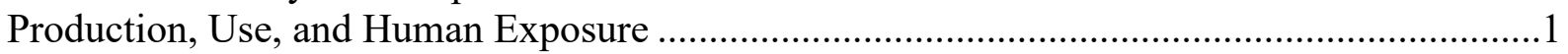

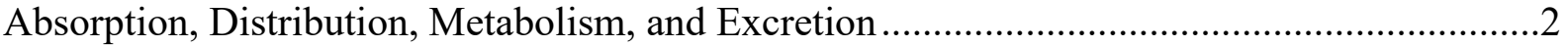

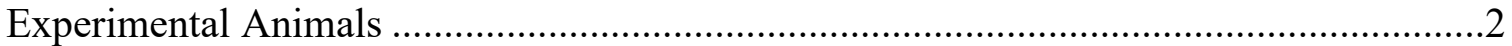

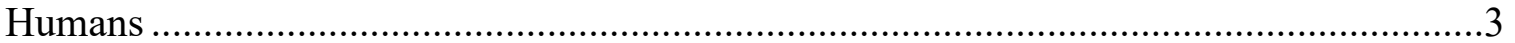

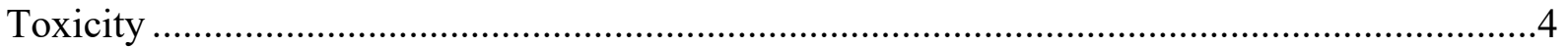

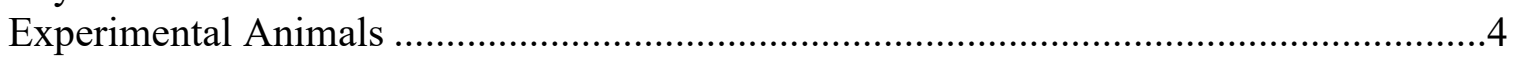

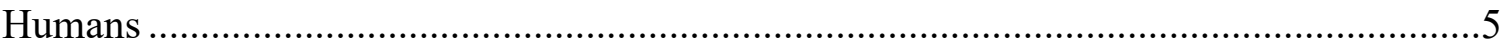

Reproductive and Developmental Toxicity .....................................................................

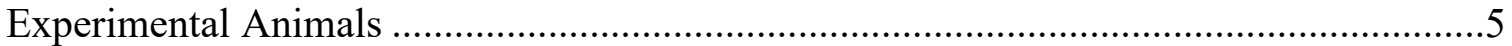

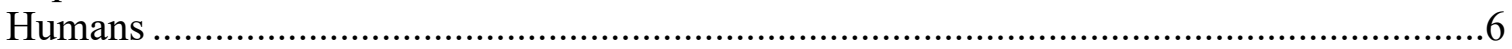

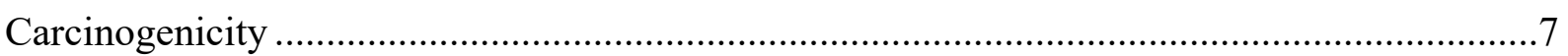

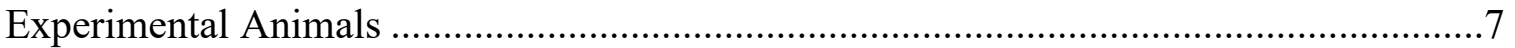

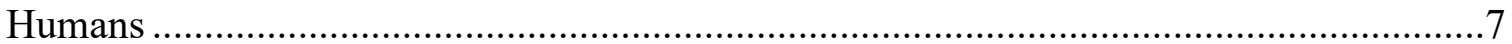

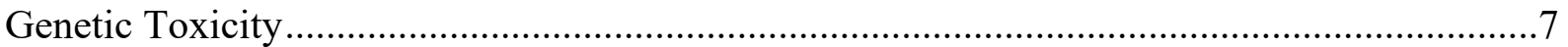

Role of the Aryl Hydrocarbon Receptor in the Toxicity of Hexachlorobenzene ....................... 8

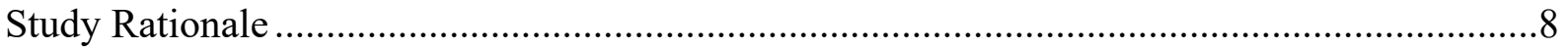

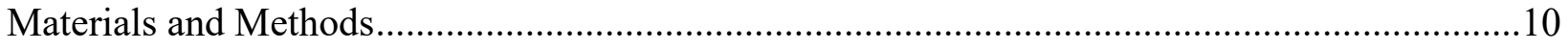

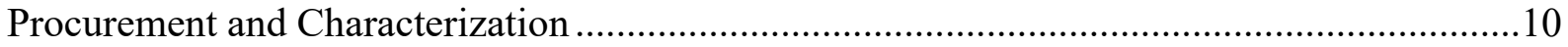

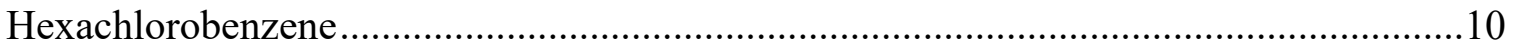

Formulation Materials..............................................................................................

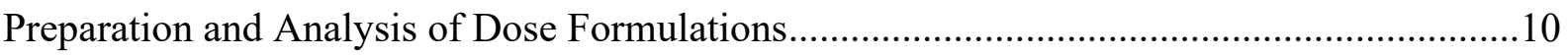

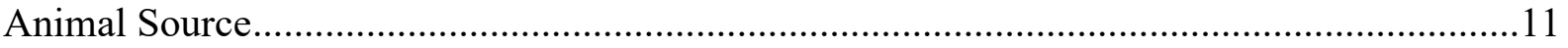

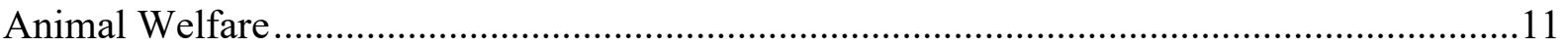

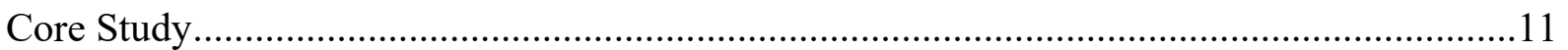

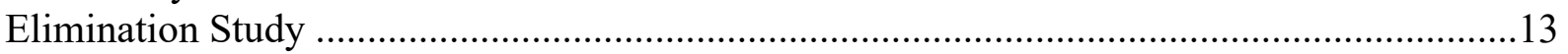

Analysis of Hexachlorobenzene in Blood and Tissue Samples ................................................14

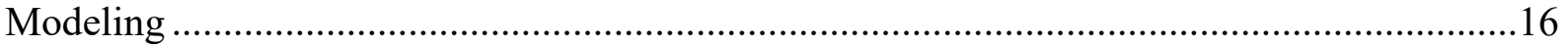

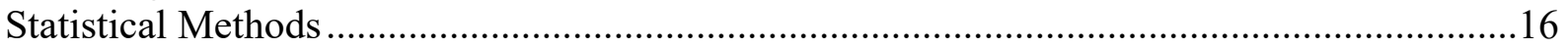

Calculation and Analysis of Nonneoplastic Lesion Incidences ..........................................16

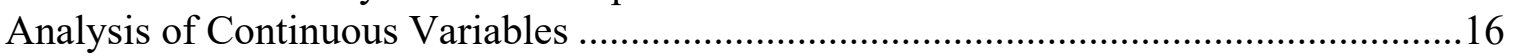




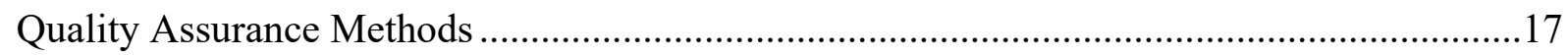

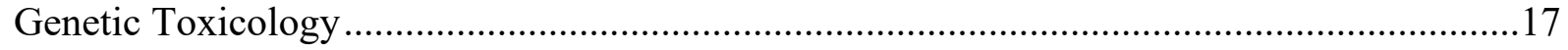

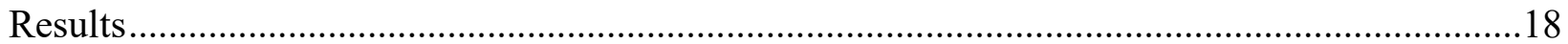

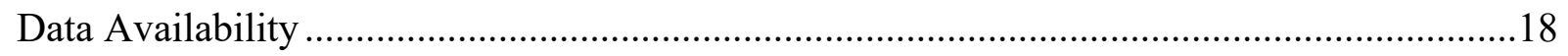

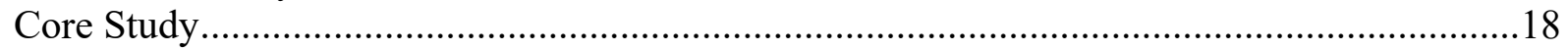

Hexachlorobenzene Concentrations in Blood and Tissues .............................................22

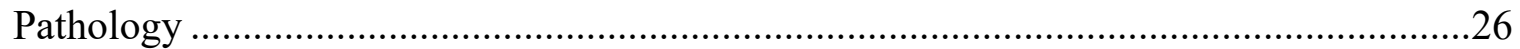

Determination of Relative Potency Factors ………….........................................................

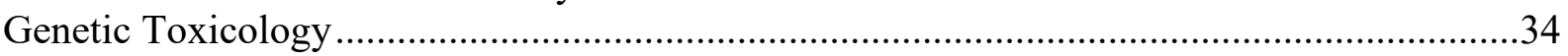

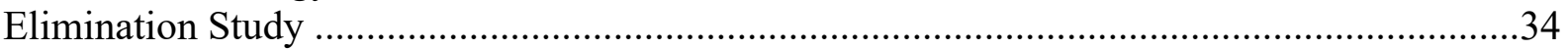

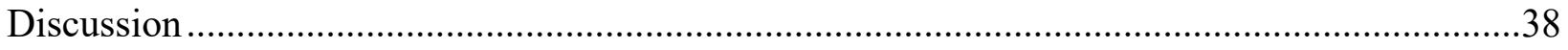

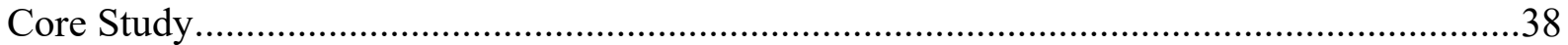

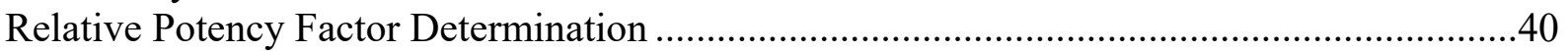

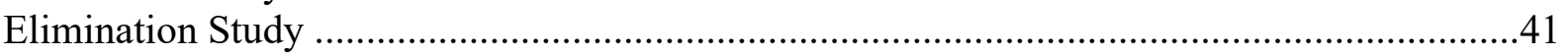

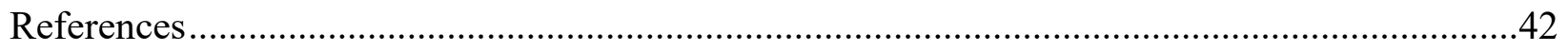

Appendix A. Chemical Characterization and Dose Formulation Studies.................................. A-1

Appendix B. Ingredients, Nutrient Composition, and Contaminant Levels in NTP-2000

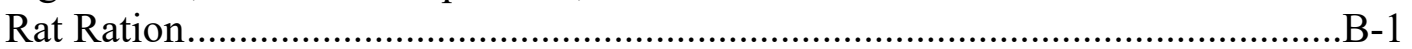

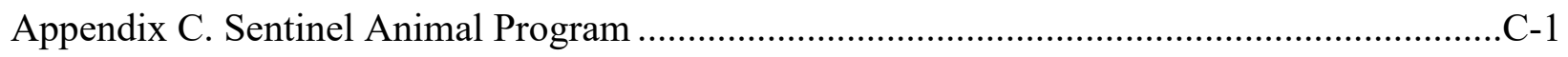

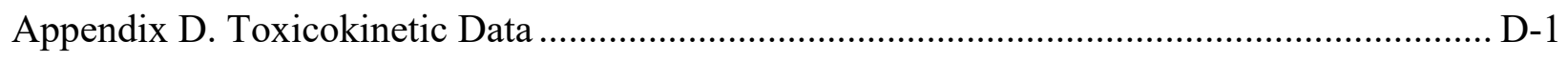

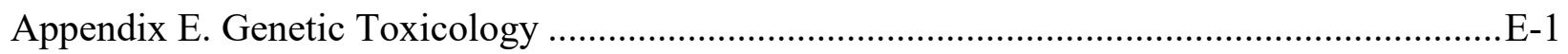

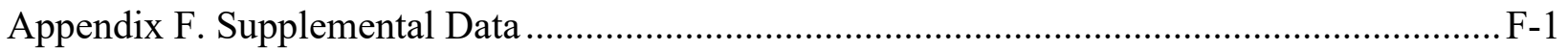

\section{Tables}

Summary of Findings Considered Toxicologically Relevant in Core Study and Elimination Study Female Rats in the Three-month Gavage Study of Hexachlorobenzene ................................................................................................... xiv

Table 1. Experimental Design and Materials and Methods in the Three-month Gavage

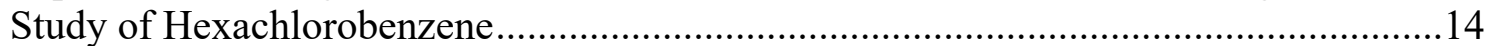

Table 2. Summary of Survival and Mean Body Weights for Core Study Female Rats in the Three-month Gavage Study of Hexachlorobenzene....................................................18

Table 3. Summary of Select Organ Weights and Organ-Weight-to-Body-Weight Ratios for Core Study Female Rats in the Three-month Gavage Study of Hexachlorobenzene

Table 4. Summary of Serum Concentrations of Thyroid Hormones for Core Study Female Rats in the Three-month Gavage Study of Hexachlorobenzene.

Table 5. Summary of Hepatic Cell Proliferation Data for Core Study Female Rats in the Three-month Gavage Study of Hexachlorobenzene.

Table 6. Summary of Hepatic Cytochrome P450 Data for Female Rats in the Gavage Studies of Hexachlorobenzene 
Table 7. Summary of Pulmonary 7-Ethoxyresorufin-O-deethylase Activity for Female Rats in the Gavage Studies of Hexachlorobenzene

Table 8. Summary of Concentrations of Hexachlorobenzene in Blood and Tissues for Core Study Female Rats in the Three-month Gavage Study of Hexachlorobenzene

Table 9. Incidences of Select Nonneoplastic Lesions in Core Study Female Rats in the Three-month Gavage Study of Hexachlorobenzene.

Table 10. Nonlinear Curve Goodness-of-Fit Values of Select Endpoints Evaluated in Female Rats Administered Hexachlorobenzene or 2,3,7,8-Tetrachlorodibenzo$p$-dioxin by Gavage for Three Months

Table 11. Summary of Select Organ Weights and Organ-Weight-to-Body-Weight Ratios for Elimination Study Female Rats in the Three-month Gavage Study of Hexachlorobenzene

Table 12. Summary of Concentrations of Hexachlorobenzene in Blood for Elimination Study Female Rats in the Three-month Gavage Study of Hexachlorobenzene .............36

Table 13. Summary of Concentrations of Hexachlorobenzene in Tissues for Elimination Study Female Rats in the Three-month Gavage Study of Hexachlorobenzene

\section{Figures}

Figure 1. Hexachlorobenzene (CASRN 118-74-1; Chemical Formula: $\mathrm{C}_{6} \mathrm{Cl}_{6}$; Molecular Weight: $284.78 \mathrm{~g})$ 1

Figure 2. Growth Curves for Core Study Female Rats Administered Hexachlorobenzene by Gavage for Three Months

Figure 3. Level II Section of a Maxillary Incisor Tooth from a Female Rat Administered $1 \mathrm{mg} / \mathrm{kg} /$ day Hexachlorobenzene Showing Minimal Incisor Degeneration

Figure 4. Level II Section of a Maxillary Incisor Tooth from a Female Rat Administered $10 \mathrm{mg} / \mathrm{kg} /$ day Hexachlorobenzene

Figure 5. Level II Section of a Maxillary Incisor Tooth from a Female Rat Administered $25 \mathrm{mg} / \mathrm{kg}$ /day Hexachlorobenzene

Figure 6. Level II Section of a Maxillary Incisor Tooth from a Vehicle Control Female Rat

Figure 7. Dose-response Curves for Plasma Free and Total Thyroxine, Triiodothyronine, and Thyroid Stimulating Hormone Levels in Female Rats Administered Hexachlorobenzene or 2,3,7,8-Tetrachlorodibenzo-p-dioxin by Gavage for Three Months

Figure 8. Dose-response Curves for Cytochrome P450 Enzyme Activity in the Liver (AC) and Lung (D) of Female Rats Administered Hexachlorobenzene or 2,3,7,8-Tetrachlorodibenzo- $p$-dioxin by Gavage for Three Months 


\section{About This Report}

National Toxicology Program ${ }^{1}$

${ }^{1}$ Division of the National Toxicology Program, National Institute of Environmental Health

Sciences, Research Triangle Park, North Carolina, USA

\section{Collaborators}

M.C. Huang, R.C. Kovi, N. Allison, C.R. Blystone, P. Brown, B.L. Burback, A.P. Clark, M.C. Cora, H.C. Cunny, M.J. DeVito, J.M. Fostel, H. Gong, S.W. Graves, R. Harris, M.R. Hejtmancik, M.J. Hooth, J.D. Johnson, A.P. King-Herbert, M. Kozak, P.H. Long, D.E. Malarkey, C. Martini, C. Myers, T.A. Peace, J.C. Peckham, G.K. Roberts, N. Sayers, A. Shan, M. Shaw, K.R. Shockley, G.S. Travlos, D.Y. Vasconcelos, S. Waidyanatha, N.J. Walker, K.D. White, R. Whittlesey, G.A. Willson, K.L. Witt

Division of the National Toxicology Program, National Institute of Environmental Health Sciences, Research Triangle Park, North Carolina, USA

Designed studies, evaluated and interpreted results, and reported findings

M.C. Huang, Ph.D., Study Scientist

C.R. Blystone, Ph.D.

M.C. Cora, Ph.D.

H.C. Cunny, Ph.D.

M.J. DeVito, Ph.D.

M.J. Hooth, Ph.D.

A.P. King-Herbert, D.V.M.

D.E. Malarkey, D.V.M., Ph.D.

G.K. Roberts, Ph.D.

K.R. Shockley, Ph.D.

G.S. Travlos, D.V.M.

S. Waidyanatha, Ph.D.

N.J. Walker, Ph.D.

K.L. Witt, M.S.

Provided oversight for data management

J.M. Fostel, Ph.D.

Experimental Pathology Laboratories, Inc., Research Triangle Park, North Carolina, USA

Evaluated and interpreted results and reported findings

R.C. Kovi, M.V.Sc., Ph.D., Study Pathologist

Provided pathology review

N. Allison, D.V.M., Ph.D.

J.C. Peckham, D.V.M., Ph.D.

G.A. Willson, B.V.M.S. 
Battelle, Columbus, Ohio, USA

Conducted studies and evaluated pathology findings

M.R. Hejtmancik, Ph.D., Principal Investigator

S.W. Graves, B.S.

J.D. Johnson, Ph.D.

T.A. Peace, D.V.M.

D.Y. Vasconcelos, D.V.M., Ph.D.

Conducted prestart chemistry activities and dose formulations

B.L. Burback, Ph.D.

S.W. Graves, B.S.

MRIGlobal, Kansas City, Missouri, USA

Conducted prestart chemistry activities, dose formulations, and biological sample analyses

R. Harris, Ph.D., Principal Investigator

A.P. Clark, B.S.E.

M. Kozak, B.G.S.

A. Shan, M.S.

K.D. White, B.S.

Pathology Associates, A Division of Charles River Laboratories, Inc., Research Triangle Park, North Carolina, USA

Coordinated NTP Pathology Working Group (July 9, 2002)

P.H. Long, D.V.M., Ph.D.

ASRC Federal, Research Triangle Park, North Carolina, USA

Prepared data for report

P. Brown, B.S.

H. Gong, M.S.

C. Martini, B.S.

C. Myers, M.S.

N. Sayers, B.S.

M. Shaw, B.S.

R. Whittlesey, M.S.

\section{Contributors}

Division of the National Toxicology Program, National Institute of Environmental Health Sciences, Research Triangle Park, North Carolina, USA

Provided oversight of external peer review

E.A. Maull, Ph.D.

M.S. Wolfe, Ph.D.

NTP Pathology Working Group, National Institute of Environmental Health Sciences, Research Triangle Park, North Carolina, USA

Participated in NTP Pathology Working Group (July 9, 2002)

N. Allison, D.V.M., Ph.D., Experimental Pathology Laboratories, Inc. 
R.A. Herbert, D.V.M., Ph.D., National Toxicology Program

A. Nyska, D.V.M., National Toxicology Program

J.C. Peckham, D.V.M., Ph.D., Experimental Pathology Laboratories, Inc.

J.C. Turnier, V.M.D., Pathology Associates, A Division of Charles River Laboratories, Inc.

D.Y. Vasconcelos, D.V.M., Ph.D., Battelle

G.A. Willson, B.V.M.S., Experimental Pathology Laboratories, Inc.

Experimental Pathology Laboratories, Inc., Research Triangle Park, North Carolina, USA

Supervised pathology review

M.H. Hamlin, II, D.V.M., Principal Investigator

SRI International, Menlo Park, California, USA

Conducted bacterial mutagenicity assays

K. Mortelmans, Ph.D., Principal Investigator

CSS Corporation, Research Triangle Park, North Carolina, USA

Prepared quality assessment audits

S. Brecher, Ph.D., Principal Investigator

S. Iyer, B.S.

V.S. Tharakan, D.V.M.

Social \& Scientific Systems, a DLH Company, Research Triangle Park, North Carolina, USA

Provided statistical analyses

R.W. Morris, M.S., Principal Investigator

L.J. Betz, M.S.

K.P. McGowan, MBA

ICF, Durham, North Carolina, USA

Provided contract oversight

D.F. Burch, M.E.M., Principal Investigator

J. Cleland, M.E.M.

J.A. Wignall, M.S.P.H.

Prepared and edited report

S.R. Gunnels, M.A.

T. Hamilton, M.S.

P. Kellar, M.S.

K.L. Magnuson, M.E.S.M.

K. O’Donovan, B.A.

K.A. Shipkowski, Ph.D.

S.J. Snow, Ph.D.

Supported peer review

C.N. Byrd, B.S.

M.C. Rooney, B.A.

A.L. Scheuer, B.A. 


\section{Biotechnical Services, Inc., Little Rock, Arkansas, USA}

Prepared report

S.R. Gunnels, M.A., Principal Investigator

L.M. Harper, B.S.

D.C. Serbus, Ph.D.

G.E. Simmons, M.A. 


\section{Peer Review}

The National Toxicology Program (NTP) conducted a peer review of the draft NTP Technical Report on the Toxicity Studies of Hexachlorobenzene (CASRN 118-74-1) Administered by Gavage to Female Sprague Dawley (Hsd:Sprague Dawley ${ }^{\circledR} S D^{\circledR}$ ) Rats by letter in May 2020 by the experts listed below. Reviewer selection and document review followed established NTP practices. The reviewers were charged to:

1. Peer review the draft NTP Technical Report on the Toxicity Studies of Hexachlorobenzene Administered by Gavage to Female Sprague Dawley (Hsd:Sprague Dawley ${ }^{\circledR} S D^{\circledR}$ ) Rats.

2. Comment on NTP's interpretations of the data.

NTP carefully considered reviewer comments in finalizing this report.

\section{Peer Reviewers}

\section{Nathaniel D. Collins, Ph.D.}

Executive Director, Drug Safety Evaluation

Bristol Myers Squibb

Bridgewater, New Jersey, USA

\section{Charles E. Wood, Ph.D.}

Senior Principal Pathologist and Molecular Pathology Lead

Boehringer Ingelheim Pharmaceuticals, Inc.

Redding, Connecticut, USA 


\section{Publication Details}

Publisher: National Toxicology Program

Publishing Location: Research Triangle Park, NC

ISSN: 2378-8992

DOI: https://doi.org/10.22427/NTP-TOX-77

Report Series: NTP Toxicity Report Series

Report Series Number: 77

Official citation: National Toxicology Program (NTP). 2021. NTP technical report on the toxicity studies of hexachlorobenzene (CASRN 118-74-1) administered by gavage to female Sprague Dawley (Hsd:Sprague Dawley ${ }^{\circledR} \mathrm{SD}^{\circledR}$ ) rats. Research Triangle Park, NC: National Toxicology Program: Toxicity Report 77.

\section{Acknowledgments}

This work was supported by the Intramural Research Program (ES103316, ES103318, and ES103319) at the National Institute of Environmental Health Sciences, National Institutes of Health and performed for the National Toxicology Program, Public Health Service, U.S. Department of Health and Human Services under contracts HHSN273201800006C, HHSN273201600011C, GS00Q14OADU417 (Order No. HHSN273201600015U), HHSN273201500014C, HHSN273201500012C, HHSN273201500006C, HHSN273201400027C, HHSN273201400020C, HHSN316201200054W, HHS273200900002C, N01-ES-65406. 


\section{Abstract}

Despite the cessation of its production and use in many parts of the world, hexachlorobenzene (HCB) remains highly persistent in the environment, and chronic, low-dose exposure to HCB in humans continues. Its structural resemblance to 2,3,7,8-tetrachlorodibenzo- $p$-dioxin (TCDD), ability to activate the aryl hydrocarbon (Ah) receptor, TCDD-like toxicities, and bioaccumulative nature suggest HCB be included in the toxic equivalency factor (TEF) methodology. Consequently, the National Toxicology Program conducted this subchronic study of HCB, including measurement of a variety of toxicological and biochemical endpoints, to allow comparison to TCDD data obtained in a previous 2-year bioassay.

Groups of 10 female Sprague Dawley (Hsd:Sprague Dawley ${ }^{\circledR} \mathrm{SD}^{\circledR}$ ) rats (core study) were administered doses of $0.03,0.1,0.3,1,3,10$, or $25 \mathrm{mg} \mathrm{HCB} / \mathrm{kg}$ body weight/day $(\mathrm{mg} / \mathrm{kg} / \mathrm{day})$ in corn oil:acetone (99:1) by gavage, 5 days/week for 13 weeks ( 3 months). Elimination of HCB after repeated dosing was evaluated in a group of 10 female rats (elimination study) administered 0.03 or $25 \mathrm{mg} / \mathrm{kg} /$ day for 13 weeks ( 3 months) and then held without dosing until necropsy at 21 (5 rats) or 29 (5 rats) weeks. Vehicle control female rats (10 core study and 10 elimination study) were administered the corn oil:acetone vehicle only. Genotoxicity in Salmonella typhimurium was also evaluated.

No significant effect of HCB on survival occurred in either the core or elimination study. In core study animals, the mean body weight gains of 10 and $25 \mathrm{mg} / \mathrm{kg} /$ day groups and the final mean body weight of the $25 \mathrm{mg} / \mathrm{kg} /$ day group were significantly increased compared to the vehicle control group. At 3 months, the absolute and relative spleen weights of the 3,10, and $25 \mathrm{mg} / \mathrm{kg} /$ day groups, liver weights of the 10 and $25 \mathrm{mg} / \mathrm{kg} /$ day groups, and lung weights of the $25 \mathrm{mg} / \mathrm{kg}$ /day group were significantly increased compared to the vehicle control group. The absolute kidney weight of the $25 \mathrm{mg} / \mathrm{kg}$ /day group was also significantly increased compared to the vehicle control group.

Free and total serum thyroxine $\left(\mathrm{T}_{4}\right)$ were significantly decreased in the 10 and $25 \mathrm{mg} / \mathrm{kg} / \mathrm{day}$ groups, and total triiodothyronine $\left(\mathrm{T}_{3}\right)$ was significantly decreased in the $25 \mathrm{mg} / \mathrm{kg} /$ day group. There were no significant changes in serum thyroid stimulating hormone (TSH). Hepatic cytochrome P450 (CYP) enzyme activity (acetanilide-4-hydroxylase [A4H], 7-ethoxyresorufin$O$-deethylase [EROD], and pentoxyresorufin- $O$-deethylase [PROD]) was increased in all dosed groups; pulmonary EROD activity was increased only at the $25 \mathrm{mg} / \mathrm{kg} /$ day dose. The incidences of hepatocyte hypertrophy and lymphoid hyperplasia of the spleen in the 10 and $25 \mathrm{mg} / \mathrm{kg} / \mathrm{day}$ groups, chronic inflammation of the lung in the 3,10 , and $25 \mathrm{mg} / \mathrm{kg} /$ day groups, and mammary gland hyperplasia, suppurative inflammation of the skin, and ulcer of the skin in the $25 \mathrm{mg} / \mathrm{kg}$ /day group were significantly increased compared to the vehicle control group. The teeth of all groups of rats administered $1 \mathrm{mg} / \mathrm{kg}$ /day or greater showed maxillary incisor degeneration.

Thyroid hormone levels, hepatocyte proliferation, and hepatic and pulmonary CYP activity data were used to determine relative potency factors (RPFs) for consideration of inclusion of HCB in the TEF methodology. Due to dissimilar maximal responses and lack of parallel dose curves of HCB and TCDD, an RPF derived from a median effective dose (ED50) could not be determined using the thyroid hormone and CYP activity values. These data suggest that although the toxicological effects are similar to those seen with TCDD administration, HCB acts through 
different or additional mechanisms than activation of the Ah receptor and should not be included in the TEF concept.

HCB was not mutagenic in any of the four strains of Salmonella typhimurium, with or without exogenous metabolic activation.

In the elimination study, the half-life of HCB was estimated to be between 48 and 53 days in blood.

Under the conditions of this 3-month gavage study, oral administration of HCB in female Sprague Dawley rats resulted in dose-related lesions in the liver, lung, spleen, mammary gland, skin, thymus, and teeth. $\mathrm{HCB}$ administration decreased total $\mathrm{T}_{3}$, free $\mathrm{T}_{4}$, and total $\mathrm{T}_{4}$; there were no compensatory increases in TSH and no thyroid histological changes observed. Consistent with literature indicating that $\mathrm{HCB}$ acts through other mechanisms in addition to activation of the Ah receptor, these data indicate that HCB should not be included in the TEF methodology.

Synonyms: benzene hexachloro-; HCB; Hexa CB; pentachlorophenyl chloride; perchlorobenzene

Trade Names: Amatin, Anticarie, Bunt-Cure, Bunt-No-More, Ceku; Co-op Hexa, Granox NM, Julian's Carbon Chloride, No Bunt, No Bunt 40, No Bunt 80, Sanocide, Smut-Go, Snieciotox 
Summary of Findings Considered Toxicologically Relevant in Core Study and Elimination Study Female Rats in the Three-month Gavage Study of Hexachlorobenzene

\begin{tabular}{|c|c|c|}
\hline & Core Study & Elimination Study \\
\hline $\begin{array}{l}\text { Doses in Corn } \\
\text { Oil:Acetone (99:1) }\end{array}$ & $0,0.03,0.1,0.3,1,3,10$, or $25 \mathrm{mg} / \mathrm{kg} / \mathrm{day}$ & $0,0.03$, or $25 \mathrm{mg} / \mathrm{kg} /$ day \\
\hline Survival Rates & $\begin{array}{l}10 / 10,9 / 10,10 / 10,10 / 10,10 / 10,10 / 10,10 / 10 \\
10 / 10\end{array}$ & $10 / 10,10 / 10,10 / 10$ \\
\hline Body Weights & $\begin{array}{l}\uparrow \text { Mean body weight gains ( } 10 \text { and } \\
25 \mathrm{mg} / \mathrm{kg} / \mathrm{day} \text { groups) } \\
\uparrow \text { Final mean body weight }(25 \mathrm{mg} / \mathrm{kg} / \text { day } \\
\text { group) }\end{array}$ & $\begin{array}{l}\text { Dosed groups similar to the vehicle } \\
\text { control group }\end{array}$ \\
\hline Clinical Findings & None $^{\mathrm{a}}$ & None \\
\hline Organ Weights & $\begin{array}{l}\uparrow \text { Absolute and relative spleen weight } \\
\uparrow \text { Absolute and relative liver weight } \\
\uparrow \text { Absolute and relative lung weight } \\
\uparrow \text { Absolute kidney weight }\end{array}$ & $\uparrow$ Absolute and relative liver weight \\
\hline Thyroid Hormones & $\begin{array}{l}\downarrow \text { Triiodothyronine } \\
\downarrow \text { Total thyroxine } \\
\downarrow \text { Free thyroxine }\end{array}$ & Not assessed ${ }^{b}$ \\
\hline $\begin{array}{l}\text { Cytochrome P450 } \\
\text { Enzyme Activity }\end{array}$ & $\begin{array}{l}\uparrow \text { Hepatic acetanilide-4-hydroxylase } \\
\uparrow \text { Hepatic pentoxyresorufin- } O \text {-deethylase } \\
\uparrow \text { Hepatic 7-ethoxyresorufin- } O \text {-deethylase } \\
\uparrow \text { Pulmonary 7-ethoxyresorufin- } O \text {-deethylase }\end{array}$ & $\begin{array}{l}\downarrow \text { Hepatic acetanilide-4-hydroxylase } \\
\uparrow \text { Hepatic 7-ethoxyresorufin- } O \text {-deethylase }\end{array}$ \\
\hline $\begin{array}{l}\text { Nonneoplastic } \\
\text { Effects }\end{array}$ & $\begin{array}{l}\text { Liver: hepatocyte hypertrophy }(0 / 10,0 / 10, \\
\text { 0/10, } 0 / 10,0 / 10,0 / 10,9 / 10,10 / 10) \\
\text { Lung: chronic inflammation }(3 / 10,1 / 10,1 / 10 \text {, } \\
\text { 2/10, } 7 / 10,8 / 10,10 / 10,10 / 10) \\
\text { Spleen: lymphoid hyperplasia }(0 / 10,0 / 10, \\
\text { 0/10, } 0 / 10,0 / 10,0 / 10,6 / 10,8 / 10) \\
\text { Mammary gland: hyperplasia }(2 / 10,2 / 10, \\
\text { 1/10, } 0 / 10,2 / 10,2 / 10,3 / 10,10 / 10) \\
\text { Skin: suppurative inflammation }(0 / 10,0 / 10, \\
\text { 0/10, } 0 / 10,0 / 10,0 / 10,0 / 10,9 / 10) \text {; ulcer }(0 / 10, \\
\text { 0/10, } 0 / 10,0 / 10,0 / 10,0 / 10,0 / 10,7 / 10) \\
\text { Thymus: atrophy }(0 / 10,1 / 10,0 / 10,0 / 10,0 / 10 \text {, } \\
\text { 0/10, 0/10, 3/10) } \\
\text { Tooth: maxillary incisor degeneration }(0 / 10, \\
\text { 0/10, } 0 / 10,0 / 10,5 / 10,10 / 10,10 / 10,10 / 10)\end{array}$ & Not assessed \\
\hline $\begin{array}{l}\text { Half-life of } \\
\text { Hexachlorobenzene }\end{array}$ & Not assessed & $\begin{array}{l}\text { Blood: } 0.03 \mathrm{mg} / \mathrm{kg} / \mathrm{day} \text { group }-53 \text { days; } \\
25 \mathrm{mg} / \mathrm{kg} / \text { day group }-48 \text { days }\end{array}$ \\
\hline \multicolumn{3}{|l|}{ Genetic Toxicology } \\
\hline $\begin{array}{l}\text { Bacterial Gene Mut: } \\
\text { with or without S9 ac }\end{array}$ & $\begin{array}{l}\text { tions: Negative in Salmonella typhimurium strain } \\
\text { vation enzymes ( } 100 \text { to } 10,000 \mu \mathrm{g} / \text { plate) }\end{array}$ & Is TA98, TA100, TA1535, and TA1537 \\
\hline
\end{tabular}




\section{Introduction}<smiles>Clc1c(Cl)c(Cl)c(Cl)c(Cl)c1Cl</smiles>

Figure 1. Hexachlorobenzene (CASRN 118-74-1; Chemical Formula: $\mathrm{C}_{6} \mathrm{Cl}_{6}$; Molecular Weight: $284.78 \mathrm{~g}$ )

Synonyms: benzene hexachloro-; HCB; Hexa CB; pentachlorophenyl chloride; perchlorobenzene.

Trade names: Amatin, Anticarie, Bunt-Cure, Bunt-No-More, Ceku; Co-op Hexa, Granox NM, Julian's Carbon Chloride, No Bunt, No Bunt 40, No Bunt 80, Sanocide, Smut-Go, Snieciotox.

\section{Chemical and Physical Properties}

Hexachlorobenzene (HCB) is an organohalogen compound with a molecular formula of $\mathrm{C}_{6} \mathrm{Cl}_{6}{ }^{1}$ At room temperature, $\mathrm{HCB}$ appears as white needles or prisms. Its water solubility is $0.005 \mathrm{mg} / \mathrm{L}$ at $25^{\circ} \mathrm{C}$, and it is readily soluble in organic solvents such as benzene, chloroform, and ether. ${ }^{2}$ The estimated log octanol:water partition coefficient of HCB is 5.5. ${ }^{1} \mathrm{HCB}$ is a stable, nonreactive compound, which slowly degrades in the environment with an estimated soil half-life between 3 and 6 years. ${ }^{3}$

\section{Production, Use, and Human Exposure}

HCB was used as a fungicide in seed treatment, particularly to control bunt, a fungal disease that affects wheat. ${ }^{1}$ It also was used in the manufacture of pyrotechnics and tracer bullets, as a fluxing agent in the manufacture of aluminum, as a wood preserving agent, as a porosity control agent in the manufacture of graphite anodes, and as a peptizing agent in the production of nitroso and styrene rubber for tires. The use and production of HCB is banned globally under the Stockholm Convention on Persistent Organic Pollutants. In the United States, all registered pesticide uses of HCB were voluntarily canceled in 1984, and it has no current uses as an end product in the United States. HCB remains an industrial by-product in the manufacture of tetrachloroethylene, perchloroethylene, and pentachlorobenzene. It is also a by-product found in several pesticides, such as pentachloronitrobenzene, chlorothalonil, Dacthal ${ }^{\circledR}$, pentachlorophenol, atrazine, simazine, propazine, and maleic hydrazide. ${ }^{1}$ Incineration of municipal waste could be another significant contributor to levels of HCB in the environment. ${ }^{4 ; 5}$

Global production of HCB between 1978 and 1981 was estimated to be 10,000 tons/year. ${ }^{6}$ United States production of HCB in 1973 was estimated at 300 tons (from three producers). ${ }^{7}$ Although no evidence of commercial production was found in the United States in 1982, HCB production as a by-product was estimated at 4,130 tons. ${ }^{8}$ Nearly $77 \%$ of this by-product was produced during the manufacture of carbon tetrachloride, trichloroethylene, and tetrachloroethylene. ${ }^{9}$ The U.S. Environmental Protection Agency (EPA) Toxic Release Inventory reports approximately 33,617 pounds of $\mathrm{HCB}$ were released in $2010 .{ }^{10}$ Of the 1,613 hazardous 
waste sites proposed for inclusion on the EPA National Priorities List, HCB has been identified in at least $107 .{ }^{3}$

Because HCB is a persistent bioaccumulative toxicant, consumption of low levels in food is likely a major route of exposure. HCB was detected in multiple food items including meats, dairy products, wheat products, and vegetables collected between 1991 and 2003 for the U.S. Food and Drug Administration's (FDA's) Total Diet Study. Average concentrations of HCB in these foods ranged from 0.01 to $0.98 \mathrm{ppb} .{ }^{11}$ Estimates of daily dietary intake in the United States from 1982 through 1984 from the FDA's Total Diet Study was 1 to $2 \mathrm{ng} / \mathrm{kg} / \mathrm{day} .{ }^{12}$ Accurate dietary intake estimations are limited by the infrequent $(<2 \%)$ detection of HCB in particular food items. For example, the Pesticide Data Program (PDP) of the U.S. Department of Agriculture (USDA) found that HCB was below the detection limit of $1 \mathrm{ppb}$ in more than 5,200 samples of fruit, vegetables, and honey. ${ }^{13}$ In contrast, approximately $42 \%$ of the heavy cream samples analyzed as part of the USDA PDP had detectable concentrations of HCB ranging from 0.2 to $0.5 \mathrm{ppb}$.

In the 2003-2004 U.S. National Health and Nutrition Examination Survey (NHANES), 99.9\% of the surveyed population had detectable serum HCB concentrations; the geometric mean was $15.9 \mathrm{ng} / \mathrm{g}$ lipid in the serum. ${ }^{14}$ In the 2013-2014 NHANES survey, the average concentration of serum HCB for samples pooled by ethnic group and age ranged from 6.18 to $21.6 \mathrm{ng} / \mathrm{g}$ lipid. ${ }^{15} \mathrm{In}$ 2010, a study found that concentrations of HCB in Mexican-American women of reproductive age born in Salinas, California, ranged from 7.5 to $701 \mathrm{ng} / \mathrm{g}$ lipid in serum. ${ }^{16}$ Due to restrictions on use and production, human tissue concentrations of HCB appear to be decreasing globally. ${ }^{17-}$ ${ }^{19}$ For example, in Sweden, tissue concentrations of HCB dropped approximately $8 \%$ per year from 1993 through $2007 .{ }^{19}$

\section{Absorption, Distribution, Metabolism, and Excretion}

\section{Experimental Animals}

Numerous absorption, distribution, metabolism, and excretion studies of HCB have been conducted in experimental animals. These studies indicate HCB is readily absorbed orally (approximately $80 \%$ ) when administered in an oil vehicle. ${ }^{1 ; 20} \mathrm{HCB}$ accumulates in tissues with high lipid content such as adipose, adrenal cortex, bone marrow, skin, thyroid gland, adrenal gland, and ovary. ${ }^{1 ; 2}$ HCB has been shown to readily transfer to the fetus, concentrate in milk, and transfer to neonates in rhesus monkeys and Sprague Dawley rats. ${ }^{22-26}$

Metabolites found in rats after exposure to HCB include pentachlorophenol, tetrachloro1,4-hydroquinone, and diverse tetra- and tri-chlorophenols. ${ }^{27}$ Another major metabolic pathway is the conjugation of $\mathrm{HCB}$ with glutathione. ${ }^{28}$ This conjugate is further metabolized by cleavage of the glycine and glutamate residues resulting in pentachlorophenyl- $N$-acetyl- $L$-cysteine. This mercapturate can be eliminated unchanged via the urine ${ }^{29 ; 30}$ or can be further metabolized by cleavage of the carbon-sulfur bond to produce pentachlorobenzenethiol, pentachlorothioanisol, tetrachloro-1,4-benzenedithiol, tetrachlorobenzenethiol, pentachlorobenzene, and other minor metabolites. ${ }^{31 ; 32}$ Metabolism has been reported to differ in male and female rats with higher excretion of pentachlorophenol, tetrachloro-1,4-benzenedithiol, and pentachlorothiophenol in females. ${ }^{33}$ 
In male Sprague Dawley rats, $\mathrm{HCB}$ was predominately eliminated as the parent chemical in the feces (16\% of dose administered).$^{34}$ The whole-body half-life of HCB in male Wistar rats given $0.2 \mathrm{mg} \mathrm{HCB}$ via gavage was approximately 20 days. ${ }^{35}$ In male Sprague Dawley rats consuming $5 \%$ HCB in the diet for 8 weeks, the half-life was 24 days. $^{21}$

A study by the National Toxicology Program (NTP) estimated toxicokinetic parameters of HCB in female Sprague Dawley rats (Appendix D). Rats were given a single intravenous (0.1 and $10 \mathrm{mg} / \mathrm{kg})$ or gavage $(0.03,0.3,30 \mathrm{mg} / \mathrm{kg})$ dose. HCB was measured in whole blood, adipose tissue, liver, and lung over the course of 84 days. After intravenous administration, the systemic exposure parameters for HCB increased linearly with dose with a half-life of approximately 3 days. After oral administration, HCB was rapidly absorbed; peak blood concentrations were reached within 4 hours. The highest concentration of HCB was in the adipose tissue, followed by liver, then lung. Kinetics of HCB in blood following oral administration appeared nonlinear. The half-life of HCB in the blood was 23 days in the lowest dose group but decreased to 12 days at the two higher doses. Bioavailability exceeded $100 \%$ at all doses and decreased at the highest dose. Collectively, these data demonstrate potential saturation of absorption and elimination processes after oral administration and route differences in disposition of HCB.

Several physiologically based pharmacokinetic (PBPK) models are available for HCB. Yesair et al. ${ }^{36}$ developed the first HCB PBPK model that describes the pharmacokinetics of repeated exposure to $\mathrm{HCB}$ in adult male and female rats and in dams and their offspring. Freeman et al. ${ }^{37}$ and $\mathrm{Lu}$ et al. ${ }^{38}$ also developed PBPK models for HCB in rats.

\section{Humans}

Absorption of inhaled HCB in humans is estimated to be minimal. Ingested HCB through foods, particularly fatty items, however, is estimated to be $85.4 \%$ absorbed when the blood of the ingesting individual contains no HCB. ${ }^{39 ;} 40$ Net absorption appears to decrease with higher accumulation of HCB in tissues and/or blood. ${ }^{39} \mathrm{HCB}$ distributes in humans depending on lipid solubility and lipid content of the tissues. ${ }^{41-43}$ As in experimental animals, HCB has been shown in humans to pass from the mother to the fetus or neonate through the placenta or breast milk. ${ }^{44-}$ 47

Metabolism of HCB in humans is not as well-documented. The rural village of Flix, Spain, surrounds an electrochemical plant that has been associated with high ambient air concentrations of HCB $\left(35 \mathrm{ng} / \mathrm{m}^{3}\right)$ for four decades. In this highly exposed human population (mean serum HCB concentrations of $39.8 \mathrm{ng} / \mathrm{mL}$ in Flix versus $4.13 \mathrm{ng} / \mathrm{mL}$ in Barcelona), high concentrations of pentachlorophenol and pentachlorobenzenethiol, a sulfur derivative, were detected in the urine. ${ }^{48}$ In samples obtained from patients in Germany, only the parent compound was detected in adipose tissue, whereas pentachlorophenol was found only in the urine. ${ }^{49}$

Similar to experimental animals, elimination of the parent chemical in humans is primarily through feces. ${ }^{50}$ Metabolites of HCB are excreted primarily through the urine. Pentachlorobenzenethiol concentrations in the urine of Flix residents in Spain correlated strongly with serum HCB concentrations, confirming that urinary excretion contains primarily metabolites of HCB. Given estimated daily elimination rates of $\mathrm{HCB}$ and its metabolites via urine and feces, the half-life of HCB was predicted to be approximately 6 years in this population. ${ }^{50}$ The PBPK model developed by Freeman et al. ${ }^{37}$ for rats was extrapolated to 
humans by incorporating human physiological parameters. ${ }^{36}$ This PBPK model predicted a half-life of 215 days ( 0.58 years) in a 15 -year-old girl with exposure to $0.5-32 \mathrm{mg} / \mathrm{kg} /$ day for 15 weeks.

\section{Toxicity}

\section{Experimental Animals}

The oral median lethal dose ( $\left.\mathrm{LD}_{50}\right)$ values for $\mathrm{HCB}$ in animals range from $1,700 \mathrm{mg} / \mathrm{kg}$ (cats) to $3,500-10,000 \mathrm{mg} / \mathrm{kg}$ (rats); $\mathrm{LD}_{50}$ values for mice, rabbits, and guinea pigs fall within that range. ${ }^{1}$ Reported effects of HCB include mainly immunological, hepatotoxicological, respiratory, and neurological effects. Short-term and subchronic oral exposure of rats to doses ranging from 30 to $250 \mathrm{mg} / \mathrm{kg}$ resulted in alterations in body weight, cutaneous lesions, tremors and other neurological signs, hepatomegaly, liver damage, and changes in porphyrin or heme metabolism. ${ }^{1}$ Biochemical alterations include induction of xenobiotic metabolizing enzymes including cytochrome P450 (CYP)1A1, CYP1A2, CYP2B, and glutathione- $S$-transferases and induction of thyroid hormone glucuronidation. ${ }^{51} \mathrm{HCB}$ also altered circulating thyroid hormone levels and increased thyroid hormone catabolism. Interestingly, the no-observed-effect levels (NOELs) for both toxic and biochemical effects are of the same order of magnitude. ${ }^{1}$

In rats, the hepatic effects of $\mathrm{HCB}$ include increased liver weight, microsomal enzyme induction, hepatocellular hypertrophy, cytoplasmic vacuolation, fatty degeneration, and biliary hyperplasia. ${ }^{3} \mathrm{HCB}$ induces CYP1A, CYP2B, and CYP3A isoforms in hepatic tissue. These data suggest that $\mathrm{HCB}$ activates the aryl hydrocarbon (Ah) receptor, the constitutive androstane receptor, and/or the pregnane $\mathrm{X}$ receptor. $\mathrm{HCB}$ does bind the Ah receptor, although it is approximately 10,000 times less potent than 2,3,7,8-tetrachlorodibenzo-p-dioxin (TCDD). ${ }^{52}$ Hepatic porphyria typically occurs in rats, provided the exposure is of sufficient dose and duration. Using CYP1A2 knockout mice, Sinclair et al. ${ }^{53}$ demonstrated that induction of porphyria by $\mathrm{HCB}$ requires CYP1A2 expression.

Several studies in rats have reported that oral exposure to HCB produces pulmonary lesions. Low-dose effects typically include hypertrophy and proliferation of the endothelial cells lining the pulmonary venules and intra-alveolar accumulation of foamy-looking macrophages. These pulmonary lesions have occurred in both sexes of six different strains of rats at doses as low as $3 \mathrm{mg} / \mathrm{kg} .{ }^{54-59}$ At doses between 25 and $50 \mathrm{mg} / \mathrm{kg}$, pulmonary lesions in rats include inflammation, edema, and decreased respiratory function. ${ }^{54 ; 59}$

Several reports explore the endocrine-disrupting effects of HCB. High doses of HCB alter ovarian function in primates and rodents. In cycling female rhesus monkeys, HCB reduced circulating concentrations of estradiol, although only one of the four animals failed to ovulate. ${ }^{60}$ In contrast, $\mathrm{HCB}$ did not alter circulating concentrations of estradiol in cycling cynomolgus monkeys but did result in lower serum progesterone concentrations during the luteal phase. ${ }^{61 ; 62}$ In superovulated female rats, animals treated with $\mathrm{HCB}$ had higher serum progesterone compared to animals that were not treated with $\mathrm{HCB} .{ }^{63} \mathrm{HCB}$ also decreases circulating thyroid hormones following repeated exposures in rats ${ }^{64-66}$ and hamsters. ${ }^{67}$ These effects appear related to increased glucuronidation of thyroxine and interactions with serum thyroid hormone transport proteins. 
HCB has immunosuppressive effects in mice and immunostimulatory effects in rats and dogs (reviewed in IPCS, ${ }^{1}$ Vos et al ${ }^{68}$ ). Male and female rats exposed to HCB had higher spleen and lymph node weights. The higher spleen weights were associated with increased incidences of extramedullary hematopoiesis and hyperplasia of the splenic B-cells. Lymph nodes had higher numbers of high endothelial venules. These histological changes were not associated with changes in cell-mediated immunity as evaluated by functional assessments of macrophages using the Listeria monocytogenes mortality assay, skin graft rejection challenges, and delayed-type hypersensitivity. HCB stimulated humoral immunity to the thymus-dependent antigen, tetanus toxoid, but did not alter the thymus-independent immunoglobulin M (IgM) response to lipopolysaccharide.

\section{Humans}

Much of what is known about the health effects of HCB in humans derives from an accidental mass poisoning in Turkey from 1955 to 1959 where as many as 3,000-5,000 people consumed HCB-treated wheat grain that was ground into flour and made into bread. ${ }^{1}$ Estimated intake of HCB in this population was 50-200 mg/day ${ }^{69}$ Observed effects included mortality $(10 \%)$, porphyria cutanea tarda, other skin lesions (erythema, bullae), ulcerations and resultant scarring, friable skin, hyperpigmentation, hypertrichosis, enlarged liver, weight loss, enlargement of lymph nodes, neurological effects, osteoporosis of the extremities, and deformation of the fingers (arthritis). Goiter was present in 27\% of exposed men and 60\% of exposed women compared to an average of 5\% among unexposed individuals in this region. Exposed infants developed pink cutaneous lesions (pembe yara or pink sore), fever, diarrhea, vomiting, weakness, convulsions, enlarged liver, and progressive wasting. At least $95 \%$ of these children died within a year of birth, and in many villages no children between the ages of 2 and 5 years survived from 1955 to 1960. ${ }^{1}$ In contrast, the Flix, Spain, cohort, which was exposed to lower concentrations, showed few associations between HCB exposure and adverse noncancer effects. ${ }^{46 ; 70 ; 71}$

\section{Reproductive and Developmental Toxicity}

\section{Experimental Animals}

In Sprague Dawley rats, perinatal exposure to $100 \mathrm{ppb} \mathrm{HCB}$ in feed (equating to an approximate consumption of $6 \mu \mathrm{g} \mathrm{HCB} / \mathrm{kg} /$ day by the dams) resulted in decreased pup body weights. ${ }^{24}$ Arnold et al. ${ }^{72}$ exposed rats to diets containing $0,0.32,1.6,8.0$, or 40 ppm of HCB for 90 days prior to mating until weaning. No effects on reproductive parameters were observed in the $\mathrm{F}_{0}$ generation; however, there were decreases in pup body weight in the top dose group. After weaning, $F_{1}$ animals were exposed to the same concentration of $\mathrm{HCB}$ as their parents and examined after 130 weeks. No HCB-induced adverse effects were reported in the $0,0.32$, and $1.6 \mathrm{ppm} \mathrm{F}$ groups. The 8.0 and $40 \mathrm{ppm}$ groups had increased incidences of hepatic centrilobular basophilic chromogenesis. Males in the $40 \mathrm{ppm}$ group also had severe chronic nephrosis. No reproductive or developmental effects were examined in the $\mathrm{F}_{1}$ animals.

A four-generation study was conducted in Sprague Dawley rats fed diets containing 0, 10, 20, $40,80,160,320$, or $640 \mathrm{ppm}$ HCB throughout mating, gestation, and lactation. The two highest exposure concentrations caused deaths in $\mathrm{F}_{0}$ dams before the first deliveries and reduced the fertility index. Animals consuming diets with concentrations of $\geq 160 \mathrm{ppm}$ HCB had a reduced litter size, increased number of stillbirths, and lower pup survival. Similar effects were seen at 
$80 \mathrm{ppm}$ after the first two generations, and $40 \mathrm{ppm}$ produced enlarged livers and higher aniline hydroxylase activity in the $\mathrm{F}_{1 \mathrm{a}}$ and $\mathrm{F}_{3 \mathrm{a}}$ pups. The dietary concentration of $20 \mathrm{ppm}$ (approximately $1-2 \mathrm{mg} / \mathrm{kg} /$ day) was designated as the NOEL. ${ }^{73}$

CD-1 mice administered $100 \mathrm{mg} / \mathrm{kg}$ by gavage on gestation days (GD) 7-16 had significantly increased incidences of abnormal fetuses per litter and one case of renal agenesis. ${ }^{74}$ Some pups were born with cleft palates, but they all occurred in one litter. Increased maternal liver-to-body weight ratios and decreased fetal body weights also occurred.

Andrews and Courtney ${ }^{75}$ administered 0 , 10, or $50 \mathrm{mg} / \mathrm{kg}$ HCB to CD-1 female mice on GD 616. In exposed pups, enlarged kidneys and hydronephrosis were observed on postnatal day (PND) 15. Similar studies in CD rats showed enlarged kidneys on PND 5 in dams administered $10 \mathrm{mg} / \mathrm{kg}$ on GD 15-20 and a significant increase in the kidney:body weight ratio and the liver:body weight ratio in HCB-exposed pups on PNDs 5, 10, and 20.

Goldey and Taylor ${ }^{23}$ reported effects on neurobehavioral development in the offspring of female rats administered 2.5 or $25 \mathrm{mg} / \mathrm{kg}$ for 4 consecutive days (10 and $100 \mathrm{mg} / \mathrm{kg}$ total), 2 weeks prior to breeding. Exposed females were bred with nonexposed males. Pups in both exposed groups were hyperactive (determined by tests of negative geotaxic reflex, olfactory discrimination, and exploratory locomotor activity) at PND 6-20. Pups from the $25 \mathrm{mg} / \mathrm{kg}$ dose group showed reduced acoustic startle response at PND 23 but an increased response at PND 90. These doses did not affect learning (as determined by the swim T-maze test) or motor activity in older offspring, nor maternal or fetal body weights, length of gestation, number of pups per litter, or number of days to eye opening.

Lilenthal et al. ${ }^{76}$ also noted neurotoxic effects in rats. Female rats were fed diets containing 0,4 , 8 , or 16 ppm HCB for 90 days prior to mating and through lactation. In contrast to Goldey and Taylor, ${ }^{23}$ no significant differences were noted on PND 21 in open-field activity or active avoidance learning on PND 90. Training of operant behavior started at PND 150 for the control, $8 \mathrm{ppm}$, and $16 \mathrm{ppm}$ groups. Dose-dependent reductions occurred in the post-reinforcement pause (i.e., time between reinforcement and the first reaction emitted). In addition, the efficiency of reinforcement was decreased in a dose-dependent manner.

Vos et al. ${ }^{77}$ evaluated the effects of HCB on the developing immune system in Wistar rats exposed to HCB in the diet starting on days 1-3 of pregnancy. Dams and pups were maintained on this diet throughout the study. The immune system was evaluated in the pups at 5 weeks of age. Resistance to Listeria monocytogenes and Trichinella sprialis was suppressed in the pups. In contrast, $\mathrm{HCB}$ enhanced the thymus-dependent antibody response to tetanus toxoid by over 16-fold. Vos et al. concluded that HCB enhances humoral immunity and suppresses cellular immunity after developmental exposures.

\section{Humans}

In the Turkish cohort, at least $95 \%$ of the children died within a year of birth, and in many villages no children between the ages of 2 and 5 years survived from 1955 to $1960 .^{1}$ In the Flix cohort, which was exposed to lower concentrations of HCB, HCB exposure was not associated with developmental neurobehavioral outcomes ${ }^{78}$ or thyroid status in neonates. ${ }^{79}$ Higher exposure concentrations of $\mathrm{HCB}$, however, were associated with premature birth, short length for gestational age, and a decrease in crown-heel length. ${ }^{80}$ An epidemiology study published in 2008 
suggested an association between perinatal HCB exposures and increases in body mass index and weight. ${ }^{81}$

\section{Carcinogenicity}

\section{Experimental Animals}

Syrian golden hamsters developed liver cell tumors (hepatoma) in both males and females after dietary exposure to $\mathrm{HCB} .{ }^{82}$ In addition, these investigators found increased incidences of hemangioendothelioma in both sexes and adenoma of the thyroid gland in males. In female mice, the incidences of hepatoma were increased after dietary exposure to 100 and 200 ppm HCB for 120 weeks. ${ }^{83}$ In a two-generation study in Sprague Dawley rats, the $F_{1}$ females had increased incidences of neoplastic liver nodules and adrenal gland pheochromocytoma. ${ }^{72}$ Males had increased incidences of parathyroid gland adenoma in the same experimental setup. In a 2-year study in Sprague Dawley rats, there were increased incidences of hepatoma, hemangiomas, hepatocellular carcinomas, bile duct carcinomas, and renal cell adenoma after consumption of 75 or $150 \mathrm{ppm}$ HCB in the diet. ${ }^{84}$ Females had increased incidences of hepatocellular carcinoma and bile duct adenoma/carcinoma, in addition to increased incidences of adrenal cortical adenoma and pheochromocytoma.

\section{Humans}

HCB is reasonably anticipated to be a human carcinogen. ${ }^{85}$ The International Agency for Research on Cancer concluded that there is inadequate evidence in humans but sufficient evidence in experimental animals for the carcinogenicity of $\mathrm{HCB} .{ }^{86 ; 87} \mathrm{EPA}$ assigned $\mathrm{HCB}$ as a probable human carcinogen (Group B2) on the basis of findings of tumors in the liver, thyroid, and kidney in three rodent species ${ }^{88}$ Increased incidences of soft-tissue sarcoma and thyroid gland neoplasms were observed in men exposed to HCB in ambient air in the Flix cohort. ${ }^{89}$ In the Turkish cohort, there was no evidence of increased cancer incidence. ${ }^{1}$ In both these analyses, however, researchers followed up with only a small fraction of the exposed population.

\section{Genetic Toxicity}

Reviews of the literature on the genotoxicity of $\mathrm{HCB}^{3 ; 90 ; 91}$ indicated that assays for mutagenic activity of HCB in bacterial or mammalian cell systems were generally negative, with some exceptions. There was some evidence that HCB might induce DNA or chromosomal damage, but the results were inconsistent across the assays.

HCB (up to 1,000 $\mu \mathrm{g} /$ plate) was not mutagenic in Salmonella typhimurium strains TA98, TA100, TA1535, or TA1537 or in Escherichia coli WP2 in the presence or absence of microsomal activation (S9). ${ }^{92}$ These results are consistent with previously reported negative results in several S. typhimurium strains treated with concentrations of HCB up to $10,000 \mu \mathrm{g} / \mathrm{plate}$, with and without S9. ${ }^{93}$ However, one study reports mutagenic activity of HCB at a lower dose, $50 \mu \mathrm{g} /$ plate, in strain TA98 exposed in the presence of S9; without S9, no mutagenic activity was observed at HCB concentrations up to $100 \mu \mathrm{g} /$ plate. ${ }^{94} \mathrm{HCB}$, in the absence of S9, induced 8 -azaguanine resistance but did not induce ouabain resistance in Chinese hamster V-79 cells. ${ }^{95}$

HCB did not induce micronuclei, biomarkers of chromosomal damage, in cultured human lymphocytes when tested without exogenous metabolic activation at concentrations of up to 
$0.1 \mathrm{mM} .{ }^{96}$ In contrast, Canonero et al.${ }^{97}$ reported significant increases in both DNA strand breaks (measured by the comet assay) and micronuclei in primary cultures of human hepatocytes exposed in vitro with concentrations of HCB up to $0.56 \mathrm{mM}$. Testing HCB under the same conditions and concentration range in rat hepatocytes did not induce DNA strand breaks but did induce a significant increase in micronuclei. Positive results in tests for induction of DNA damage by HCB $(1 \mu \mathrm{g} / \mathrm{mL})$ were also reported in National Institutes of Health 3T3 mouse embryonic and WS1 human primary embryonic fibroblast cells. ${ }^{98}$ Despite the observations of induced DNA damage and micronuclei, no chromosomal aberrations were detected in cultured human peripheral blood lymphocytes after exposure to HCB up to $0.1 \mathrm{mM}{ }^{92}$ Results of a study designed to evaluate HCB-induced DNA damage in an E. coli test system (differential growth in wild-type and DNA repair-deficient strains) were negative. ${ }^{92}$

In vivo, $\mathrm{HCB}$ (doses of up to $221 \mathrm{mg} / \mathrm{kg}$ in corn oil) failed to induce dominant lethal mutations in germ cells of male rats (strain not specified) treated once daily by gavage for 5 days. ${ }^{99}$ In addition, no dominant lethal mutations were observed in male Wistar rats that were administered doses up to $60 \mathrm{mg} / \mathrm{kg}$ for 10 days. ${ }^{100} \mathrm{HCB}$, at a dose of $25 \mathrm{mg} / \mathrm{kg}$, bound to rat liver DNA, with or without pretreatment with phenobarbital. ${ }^{94}$

\section{Role of the Aryl Hydrocarbon Receptor in the Toxicity of Hexachlorobenzene}

HCB and TCDD share many chemical properties and have similar biological effects. They are both planar persistent organic pollutants. Like TCDD, HCB binds to the Ah receptor and induces some of the same toxicities as TCDD induces. HCB is also a rodent liver tumor promoter that induces CYP1A enzymes ${ }^{101}$ in rats and mice. ${ }^{52 ; 102}$ Studies in C57BL/6J mice congenic at the Ah locus indicate that mice with some expression of the Ah receptor develop porphyria earlier and to a much greater extent than mice that do not express the receptor. ${ }^{103} \mathrm{Hahn}$ and colleagues determined that HCB is a weak Ah receptor agonist, suggesting that some of the toxicity of $\mathrm{HCB}$ is mediated through its interaction with the Ah receptor. HCB also exerts effects independent of the Ah receptor. For example, HCB induces CYP2B enzymes, ${ }^{101}$ which are typically mediated through interactions with the constitutive androstane receptor. In a mammary gland tumor promotion study, HCB exposure alone did not increase the incidence and multiplicity of tumors, but the combination of HCB and N-nitroso-N-methylurea (NMU) increased the incidence and multiplicity of mammary gland tumors compared to animals treated by NMU alone. ${ }^{104}$ The mammary gland effects appear to be mediated through activation of c-SRC and estrogen receptor and are independent of the Ah receptor. ${ }^{105}$

\section{Study Rationale}

$\mathrm{HCB}$ is of concern due to widespread human exposure and its structural resemblance to a well-characterized toxicant, TCDD. Indeed, in experimental animals, HCB induces some biological effects similar to TCDD. HCB was proposed for study as part of the toxic equivalency factor (TEF) initiative to generate suitable data to establish relative potency factors (RPFs) for the class of chemicals similar to TCDD, that is, dioxin-like compounds or dioxins. The rationale and overview of the TEF studies is presented in the NTP technical report for 3,3',4,4',5-pentachlorobiphenyl (PCB 126). ${ }^{106}$ Briefly, the TEF methodology is a relative potency scheme that ranks the activity of a compound relative to TCDD. This method allows for 
the estimation of the dioxin-like activity of a mixture of chemicals with the assumption that the chemicals bind to the Ah receptor, a common mechanism of action. An application of the TEF methodology includes the prediction of cancer risk, particularly of chemical (dioxins) mixtures. The dioxin TEF studies were conducted at NTP in female Sprague Dawley rats and were predicated on prior observations by Kociba et al. ${ }^{107}$ of the carcinogenicity of TCDD in Spartan Sprague Dawley rats. The primary goal of the present study was to generate data that would enable a decision on whether to include HCB in the TEF studies at NTP. RPFs for various toxicological and biochemical endpoints after $\mathrm{HCB}$ exposure were generated and compared to TCDD data generated in the TEF studies. ${ }^{108}$

Human exposure to $\mathrm{HCB}$ is predominately from the diet through consumption of contaminated foods. Because the oral route is the most likely means of exposure, HCB was administered by oral gavage in the current study. Oral gavage was also the route of exposure for the TCDD TEF studies. ${ }^{108}$ 


\section{Materials and Methods}

\section{Procurement and Characterization}

\section{Hexachlorobenzene}

Hexachlorobenzene (HCB) was obtained from Aldrich Chemical Company (Milwaukee, WI) in one lot $(03915 \mathrm{CU})$ that was used in the 3 -month study. Identity and purity analyses were conducted by the analytical chemistry laboratory at Midwest Research Institute (MRIGlobal, Kansas City, MO); additional identity analyses were conducted by the study laboratory at Battelle (Columbus, OH) (Appendix A). One additional lot (08526EF) was procured from Aldrich Chemical Company by the analytical chemistry laboratory solely for dose formulation stability studies. Reports on analyses performed in support of the HCB study are on file at the National Institute of Environmental Health Sciences (NIEHS).

The chemical, a white powder, was identified as HCB by the analytical chemistry laboratory using infrared (IR) spectroscopy and gas chromatography (GC) coupled with mass spectrometry. The study laboratory confirmed the identity of the test article by IR spectroscopy.

The purity of lot $03915 \mathrm{CU}$ was determined by GC with flame ionization detection (GC/FID). The purity assay indicated one major peak and one impurity with a peak area equal to $0.05 \%$ of the total peak area. The overall purity of lot $03915 \mathrm{CU}$ was determined to be $>99 \%$.

After the scheduled termination of the animals, bulk chemical reanalysis was performed by the study laboratory using GC/FID, and no degradation of the bulk chemical was detected. To ensure stability, the bulk chemical was stored at room temperature in an amber glass bottle.

\section{Formulation Materials}

United States Pharmacopeia (USP)-grade corn oil was obtained from Spectrum Quality Products (Gardena, CA) in two lots and was used with one lot of USP-grade acetone (Spectrum Quality Products) as the vehicle in the 3-month gavage study. The identity of the acetone was confirmed by the study laboratory using IR spectroscopy prior to its use. Purity of the acetone was determined to be $\geq 99.9 \%$ by the study laboratory using GC/FID. The corn oil was analyzed twice by the study laboratory for peroxide levels by potentiometric titration; both measured values were below the rejection criterion of $3 \mathrm{mEq} / \mathrm{kg}$.

\section{Preparation and Analysis of Dose Formulations}

The dose formulations were prepared by mixing stock solutions of HCB with the vehicle (corn oil:acetone [99:1]) to achieve the required concentrations (Table A-2). The dose formulations were stored in amber glass bottles sealed with Teflon ${ }^{\circledR}$-lined lids at room temperature for up to 34 days.

The study laboratory determined that a $10 \mathrm{mg} / \mathrm{mL}$ dose formulation was gavagable using a 20-gauge needle.

Homogeneity studies of the 0.012 and $10.0 \mathrm{mg} / \mathrm{mL}$ dose formulations in corn oil:acetone (99:1) were performed by the study laboratory using GC with electron capture detection (ECD). 
Stability studies of a $1 \mu \mathrm{g} / \mathrm{mL}$ dose formulation made with lot $08526 \mathrm{EF}$ dissolved in $100 \%$ corn oil were performed by the analytical chemistry laboratory using GC/ECD. Homogeneity was confirmed, and stability for at least 35 days was confirmed for dose formulations stored in sealed containers in the dark at $5^{\circ} \mathrm{C}$ and $25^{\circ} \mathrm{C}$ and for at least 3 hours under simulated animal room conditions.

Periodic analyses of the dose formulations of HCB were conducted by the study laboratory using GC/ECD. During the 3-month study, the dose formulations were analyzed at the beginning, midpoint, and termination; all 21 dose formulations were within $10 \%$ of the target concentrations (Table A-3). Animal room samples of these dose formulations were also analyzed; 20 of 21 animal room samples were within $10 \%$ of the target concentrations.

\section{Animal Source}

Female Sprague Dawley (Hsd:Sprague Dawley ${ }^{\circledR} \mathrm{SD}^{\circledR}$ ) rats were obtained from Envigo (formerly Harlan Laboratories, Inc., Indianapolis, IN).

\section{Animal Welfare}

Animal care and use were in accordance with Public Health Service Policy on Humane Care and Use of Animals. All animal studies were conducted in an animal facility accredited by AAALAC International. Studies were approved by the Battelle (Columbus, $\mathrm{OH}$ ) Animal Care and Use Committee and conducted in accordance with all relevant National Institutes of Health and National Toxicology Program (NTP) animal care and use policies and applicable federal, state, and local regulations and guidelines.

\section{Core Study}

Rats were approximately 6 weeks old upon receipt, were quarantined for 13 days, and were 8 weeks old when placed on study. Before the study began, 10 female rats were randomly selected for parasite evaluation and gross observation for evidence of disease. Blood samples were collected from 10 sentinel female rats at 4 weeks and from 9 sentinel female rats at study termination. The sera were analyzed for antibody titers to rodent viruses. ${ }^{109-111}$ Additionally, the health of the animals was monitored during the studies according to the protocols of the NTP Sentinel Animal Program (Appendix C). All test results were negative.

Groups of 10 female rats were administered doses of $0.03,0.1,0.3,1,3,10$, or $25 \mathrm{mg} \mathrm{HCB} / \mathrm{kg}$ body weight/day ( $\mathrm{mg} / \mathrm{kg} /$ day) in corn oil:acetone (99:1) by gavage 5 days per week for 13 weeks (3 months). Ten vehicle control female rats were administered the corn oil:acetone vehicle only. The dosing volume was $2.5 \mathrm{~mL} / \mathrm{kg}$ body weight. Dose selection for this study was informed by the NTP 2-year study of 3,3',4,4',5-pentachlorobiphenyl (PCB 126) ${ }^{106}$ and used relative potency values of 0.1 for PCB 126 and 0.0001 for HCB. ${ }^{112}$ Accordingly, HCB concentrations needed to be 1,000 times greater than those used in the PCB 126 study (10-1,000 ng/kg/day). Additionally, previous chronic exposure studies of HCB in Sprague Dawley rats suggested that the range 0.3$25 \mathrm{mg} / \mathrm{kg}$ sufficiently covered the no-observed-effect level and lowest-observed-effect level for pertinent endpoints. ${ }^{72 ; 113 ; 114}$

Feed and water were available ad libitum; information on feed composition and contaminants is provided in Appendix B. Rats were housed five per cage. Clinical findings were recorded at the 
study start, weekly thereafter, and at necropsy. Rats were weighed at study start, weekly for 13 weeks, and at necropsy.

At study termination ( 1 day after the last dose), blood was collected by cardiac puncture and processed into serum for thyroid hormone analyses. Radioimmunoassays were performed for thyroid stimulating hormone (TSH), total triiodothyronine $\left(\mathrm{T}_{3}\right)$, and free thyroxine $\left(\mathrm{T}_{4}\right)$ using a Packard Cobra II gamma counter (Packard Instrument Company, Meriden, CT). The assay for total $\mathrm{T}_{4}$ was performed on a Hitachi $911^{\circledR}$ chemistry analyzer (Boehringer Mannheim, Indianapolis, IN) using a Boehringer Mannheim ${ }^{\circledR}$ enzyme immunoassay test system. Thyroid hormone data were summarized using the XYBION system (XYBION Medical Systems Corporation, Cedar Knolls, NJ).

For cell proliferation analyses, all core study rats received drinking water containing $40 \mathrm{mg}$ bromodeoxyuridine (BrdU)/100 mL Milli-Q water for 5 days before necropsy. BrdU solutions were administered in amber glass water bottles (Allentown Caging Equipment Company, Inc., Allentown, NJ) equipped with Teflon-lined lids and stainless-steel sipper tubes. Water consumption was measured daily for 5 days. The cell turnover rate in the liver of dosed rats was compared with the turnover rate in the vehicle control rats by determining the incorporation of BrdU into hepatocytes. A sample of duodenum (positive control) and liver was fixed in 10\% neutral buffered formalin for 18 to 24 hours and then transferred to $70 \%$ ethanol. Representative sections of the duodenum and liver were trimmed and embedded, and two sections were cut. One section was stained with hematoxylin and eosin (H\&E) and the other with anti-BrdU antibody complexed with avidin and biotin. Potential interlobular variation was determined in the vehicle control and $25 \mathrm{mg} / \mathrm{kg} /$ day groups by counting stained cells in the left lobe and right median lobe. Interlobular variation $>25 \%$ was considered significant. For the remaining core study rats, stained cells only in the left lobe were counted. At least 2,000 labeled or unlabeled hepatocyte nuclei were counted using a $20 \times$ objective and an ocular grid. The labeling index is expressed as the percentage of total nuclei labeled with BrdU.

For determination of cytochrome P450 (CYP) activities, liver and lung tissue samples were collected at necropsy and stored frozen at $-70^{\circ} \mathrm{C}$. Microsomal suspensions were prepared using the Pearce Method. ${ }^{115}$ The concentration of each protein in each suspension was determined using the microtiter plate method of the Coumassie ${ }^{\circledR}$ Plus Protein Assay (Pierce Chemical Co., Rockford, IL) with bovine serum albumin as the standard. CYP1A1-associated 7-ethoxyresorufin- $O$-deethylase (EROD), CYP1A2-associated acetanilide-4-hydroxylase (A4H), and CYP2B-associated pentoxyresorufin- $O$-deethylase (PROD) activities were determined in microsomal proteins isolated from frozen liver tissue according to established procedures. Only EROD activity was evaluated in microsomal proteins isolated from frozen lung tissue. Data are shown as pmol/minute/mg (EROD and PROD) or nmol/minute/mg (A4H) microsomal protein.

For analyses of HCB tissue concentrations, adipose, liver, and lung samples were taken from all animals at necropsy. Blood was collected via cardiac puncture from 10 core study rats per group at necropsy, mixed with heparin, and refrigerated at $5^{\circ} \mathrm{C}$.

Necropsies were performed on all rats. At necropsy, the liver, right kidney, lung, left ovary, spleen, thymus, and thyroid gland were weighed. Tissues for microscopic examination were fixed and preserved in 10\% neutral buffered formalin, processed and trimmed, embedded in paraffin, sectioned to a thickness of 4 to $6 \mu \mathrm{m}$, and stained with H\&E. Complete 
histopathological examinations were performed on vehicle control and $25 \mathrm{mg} / \mathrm{kg} /$ day groups. Table 1 lists the tissues and organs examined.

After a review of the laboratory reports and selected histopathology slides by a quality assessment pathologist, the findings and reviewed slides were submitted to an NTP Pathology Working Group (PWG) coordinator for a second independent review. Any inconsistencies in the diagnoses made by the laboratory and quality assessment pathologists were resolved by the NTP pathology peer-review process. Final diagnoses for reviewed lesions represent a consensus among the laboratory pathologist, NTP pathologist, reviewing pathologist(s), if any, and the PWG coordinator. Details of these review procedures have been described, in part, by Maronpot and Boorman ${ }^{116}$ and Boorman et al. ${ }^{117}$

\section{Elimination Study}

A set of animals was allocated to evaluate the clearance of HCB after repeated exposures. Rats were approximately 6 weeks old upon receipt, were quarantined for 14 days, and were 8 weeks old when placed on study. Before the study began, 10 female rats were randomly selected for parasite evaluation and gross observation for evidence of disease. Blood samples were collected from 10 sentinel female rats at 4 weeks and from 9 sentinel female rats at study termination. The sera were analyzed for antibody titers to rodent viruses. ${ }^{109-111}$ Additionally, the health of the animals was monitored during the studies according to the protocols of the NTP Sentinel Animal Program (Appendix C). All test results were negative.

Groups of 10 female rats were administered 0.03 or $25 \mathrm{mg} / \mathrm{kg} /$ day HCB in corn oil:acetone (99:1) by gavage 5 days per week for 13 weeks ( 3 months) and then held without dosing until necropsy 8 weeks after the last dose (week $21, \mathrm{n}=5$ ) or 16 weeks after the last dose (week 29, $\mathrm{n}=5$ ). Ten vehicle control female rats were administered the corn oil:acetone vehicle only. The dosing volume was $2.5 \mathrm{~mL} / \mathrm{kg}$ body weight. Feed and water were available ad libitum. Rats were housed five per cage. Rats were weighed at study start, weekly for 13 weeks, and at necropsy.

For determination of CYP activities, liver and lung tissue samples were collected at week 21 or 29 and stored frozen at $-70^{\circ} \mathrm{C}$. Microsomal suspensions were prepared using the Pearce Method. ${ }^{115}$ The concentration of each protein in each suspension was determined using the microtiter plate method of the Coomassie Plus Protein Assay (Pierce Chemical Co., Rockford, IL) with bovine serum albumin as the standard. CYP1A1-associated EROD and CYP1A2-associated A4H activities were determined in microsomal proteins isolated from frozen liver tissue according to established procedures. Only EROD activity was assayed in microsomal proteins isolated from frozen lung tissues. Data are shown as $\mathrm{pmol} / \mathrm{minute} / \mathrm{mg}$ (EROD) or $\mathrm{nmol} /$ minute/mg (A4H) microsomal protein.

For analyses of HCB tissue concentrations, adipose, liver, and lung samples were taken from five rats per group at weeks 21 and 29. Blood was collected via retroorbital sinus puncture from elimination study animals. Blood was collected from all 10 rats per group on day 90 . On days 104, 132, and 146, blood was collected from five rats per group; blood was collected from the remaining five rats in each group on days 118, 160, 174, and 201. Blood was mixed with heparin and refrigerated at $-5^{\circ} \mathrm{C}$.

Necropsies were performed on all rats. At necropsy, the liver, lung, thymus, and thyroid gland of all animals were weighed. No microscopic examinations were conducted. 


\section{Analysis of Hexachlorobenzene in Blood and Tissue Samples}

Blood and tissue samples were analyzed for HCB concentrations using a validated analytical method (Appendix D). Briefly, $100 \mu \mathrm{L}$ of blood was added to $100 \mu \mathrm{L}$ of acetonitrile and extracted with hexane. Tissue samples $(0.1-0.3 \mathrm{~g})$ were prepared similarly to blood samples except tissues were homogenized prior to acetonitrile precipitation and hexane extraction. All samples, standards, and blanks were analyzed using GC/ECD.

Table 1. Experimental Design and Materials and Methods in the Three-month Gavage Study of Hexachlorobenzene

\section{Three-month Study}

\section{Study Laboratory}

Battelle (Columbus, OH)

Strain and Species

Sprague Dawley (Hsd:Sprague Dawley ${ }^{\circledR} \mathrm{SD}^{\circledR}$ ) rats

Animal Source

Envigo (formerly Harlan Laboratories, Inc.; Indianapolis, IN)

Time Held Before Study

Core study: 13 days

Elimination study: 14 days

Average Age When Study Began

8 weeks

Date of First Dose

Core study: January 10, 2001

Elimination study: January 11, 2001

Duration of Dosing

13 weeks (3 months)

Date of Last Dose

Core study: April 11, 2001

Elimination study: April 10, 2001

Necropsy Dates

Core study: April 12, 2001

Elimination study: June 5, 2001 or July 30, 2001

Average Age at Necropsy

Core study: 21 weeks

Elimination study: 29 or 36 weeks

Size of Study Groups

10 females 


\section{Three-month Study}

\section{Method of Distribution}

Animals were distributed randomly into groups of approximately equal initial mean body weights.

\section{Animals per Cage}

5

\section{Method of Animal Identification}

Tail tattoo

Diet

NTP-2000 irradiated pellet diet (Zeigler Brothers, Inc., Gardners, PA), available ad libitum, changed weekly

Water

Tap water (Columbus municipal supply) via automatic watering system (Edstrom Industries, Waterford, WI), except via amber glass bottles during BrdU administration, available ad libitum

\section{Cages}

Solid-bottom polycarbonate (Lab Products, Inc., Seaford, DE); changed twice a week

\section{Bedding}

Irradiated, heat-treated hardwood chips (P.J. Murphy Forest Products Corp., Montville, NJ); changed twice a week

\section{Cage Filters}

DuPont 2024 spun-bonded polyester (Snow Filtration Co., Cincinnati, OH); changed every 2 weeks

\section{Racks}

Stainless steel (Lab Products, Inc., Seaford, DE); changed and rotated every 2 weeks

Animal Room Environment

Temperature: $72^{\circ} \mathrm{F} \pm 3^{\circ} \mathrm{F}$

Relative humidity: $50 \% \pm 15 \%$

Room fluorescent light: 12 hours/day

Room air changes: at least 10/hour

\section{Doses}

$0,0.03,0.1,0.3,1,3,10$, or $25 \mathrm{mg} / \mathrm{kg} /$ day (core study) or $0,0.03$, or $25 \mathrm{mg} / \mathrm{kg} /$ day (elimination study) in corn oil:acetone (99:1) by gavage (dosing volume $2.5 \mathrm{~mL} / \mathrm{kg}$ )

\section{Type and Frequency of Observation}

Observed twice daily; rats were weighed at study start, weekly for 13 weeks, and at study termination; clinical findings were recorded for core study rats at study start, weekly thereafter, and at study termination.

\section{Method of Euthanasia}

$100 \%$ carbon dioxide

\section{Necropsy}

Necropsies were performed on all animals. Organs weighed for core study rats were liver, right kidney, lung, left ovary, spleen, thymus, and thyroid gland. Organs weighed for elimination study rats were liver, lung, thymus, and thyroid gland.

\section{Thyroid Hormone Analysis}

At study termination, blood was collected from core study rats by cardiac puncture for thyroid stimulating hormone, total triiodothyronine, and total and free thyroxine determinations.

\section{Cell Proliferation}




\section{Three-month Study}

For 5 days before study termination at 3 months, core study rats received BrdU in drinking water. Samples of liver and duodenum were measured for BrdU labeling.

\section{Cytochrome P450 Activities}

At study termination (core study) and at week 21 or 29 (elimination study), tissue samples were taken for 7-ethoxyresorufin- $O$-deethylase (liver and lung), 7-pentoxyresorufin- $O$-deethylase (liver, core study only), and acetanilide-4-hydroxylase (liver) activities.

\section{Blood and Tissue Concentration Analyses}

At study termination (core study rats) and day 146 and 201 (elimination study rats), adipose, liver, and lung tissue samples were collected. Blood was collected at study termination on day 93 (core study rats); on day 90 (10 elimination study rats); on days 104, 132, and 146 (5 elimination study rats); or on days 118, 160, 174, and 201 (5 elimination study rats). Tissue and blood samples were analyzed for hexachlorobenzene concentrations.

\section{Histopathology}

Histopathology was performed on all core study rats in the vehicle control and $25 \mathrm{mg} / \mathrm{kg} /$ day groups. In addition to gross lesions and tissue masses, the following tissues were examined: adrenal gland, small intestine (duodenum), kidney, liver, lung, mammary gland, nose, ovary, pancreas, pituitary gland, skin, spleen, stomach (forestomach), teeth, thymus, thyroid gland, tongue, uterus, and vagina. The liver, lung, mammary gland, skin, spleen, teeth, and thymus were examined to a no-effect level in the remaining core study groups. Histopathological evaluation was not done for tissues collected from rats in the elimination study.

\section{Modeling}

Elimination study: Concentrations of HCB in blood after cessation of exposure were modeled in GraphPad Prism (La Jolla, CA) using a one-phase decay model to determine the half-life of HCB.

Determination of RPF: Thyroid hormones, hepatic and pulmonary P450 enzyme activities, and hepatocyte proliferation data were modeled in GraphPad Prism (La Jolla, CA). Data for 2,3,7,8-tetrachlorodibenzo- $p$-dioxin (TCDD) exposure at these endpoints were taken from NTP Technical Report 521. ${ }^{108}$ Data from HCB and TCDD were fit with various models (one-phase association, specific binding with Hill slope, exponential growth).

\section{Statistical Methods}

\section{Calculation and Analysis of Nonneoplastic Lesion Incidences}

The incidences of nonneoplastic lesions are presented as the numbers of animals bearing such lesions at a specific anatomic site and as the numbers of animals with that site examined microscopically. Fisher's exact test, ${ }^{118}$ a procedure that uses the overall proportion of affected animals, was used to determine significance between exposed and vehicle control animals, and the Cochran-Armitage trend test was used to test for significant trends. ${ }^{119}$

\section{Analysis of Continuous Variables}

Two approaches were employed to assess the significance of pairwise comparisons between dosed and vehicle control groups in the analysis of continuous variables. Organ and body weight data, which historically have approximately normal distributions, were analyzed with the parametric multiple comparison procedures of Dunnett ${ }^{120}$ and Williams. ${ }^{121 ; 122}$ Thyroid hormone, cell proliferation, and cytochrome P450 data, which typically have skewed distributions, were 
analyzed using the nonparametric multiple comparison methods of Shirley ${ }^{123}$ (as modified by Williams ${ }^{124}$ ) and Dunn. ${ }^{125}$ The Jonckheere test ${ }^{126}$ was used to assess the significance of the doserelated trends and to determine whether a trend-sensitive test (the Williams or Shirley test) was more appropriate for pairwise comparisons than would be a test that does not assume a monotonic dose-related trend (Dunnett's or Dunn's test). Before statistical analysis, extreme values identified by the outlier test of Dixon and Massey ${ }^{127}$ were examined by NTP personnel, and implausible values were eliminated from the analysis.

\section{Quality Assurance Methods}

The 3-month studies were conducted in compliance with U.S. Food and Drug Administration Good Laboratory Practice Regulations. ${ }^{128}$ In addition, the 3-month study reports were audited retrospectively by an independent quality assurance contractor against study records submitted to the NTP Archives. Separate audits covered completeness and accuracy of the pathology data, pathology specimens, final pathology tables, and a draft of this NTP Toxicity Study Report. Audit procedures and findings are presented in the reports and are on file at NIEHS. The audit findings were reviewed and assessed by NTP staff, and all comments were resolved or otherwise addressed during the preparation of this Toxicity Report.

\section{Genetic Toxicology}

The genetic toxicity of HCB was assessed by testing the ability of the chemical to induce mutations in various strains of Salmonella typhimurium. The protocol for these studies and the results are given in Appendix E.

Testing was performed as reported by Haworth et al. ${ }^{93} \mathrm{HCB}$ was sent to the laboratory as a coded aliquot from Radian Corporation (Austin, TX). It was incubated with the Salmonella typhimurium tester strains TA98, TA100, TA1535, and TA1537 either in buffer or S9 mix (metabolic activation enzymes and cofactors from Aroclor 1254-induced male Sprague Dawley rat or Syrian hamster liver) for 20 minutes at $37^{\circ} \mathrm{C}$. Top agar supplemented with $L$-histidine and $d$-biotin was added, and the contents of the tubes were mixed and poured onto the surfaces of minimal glucose agar plates. Histidine-independent mutant colonies arising on these plates were counted after 2 days of incubation at $37^{\circ} \mathrm{C}$.

Each trial consisted of triplicate plates of concurrent positive and negative controls and of five doses of HCB. In the absence of toxicity, the high dose was limited by experimental design to $10,000 \mu \mathrm{g} /$ plate. All trials were repeated.

In this assay, a positive response is defined as a reproducible, dose-related increase in histidine-independent (revertant) colonies in any one strain/activation combination. An equivocal response is defined as an increase in revertants that is not dose-related, reproducible, or of sufficient magnitude to support a determination of mutagenicity. A negative response is obtained when no increase in revertant colonies is observed following chemical treatment. No minimum percentage or fold-increase is required for a chemical to be judged positive or weakly positive. 


\section{Results}

\section{Data Availability}

The National Toxicology Program (NTP) evaluated all study data. Data relevant for evaluating toxicological findings are presented here. All study data are available in the NTP Chemical Effects in Biological Systems (CEBS) database: https://doi.org/10.22427/NTP-DATA-TOX$77 . .^{129}$

\section{Core Study}

One $0.03 \mathrm{mg} \mathrm{HCB} / \mathrm{kg}$ body weight/day ( $\mathrm{mg} / \mathrm{kg} /$ day) core study rat died during week 13 of the study; all other rats survived to study termination (Table 2; Appendix F). The mean body weight gains of the 10 and $25 \mathrm{mg} / \mathrm{kg} /$ day groups and the final mean body weight of the $25 \mathrm{mg} / \mathrm{kg} / \mathrm{day}$ group were significantly increased compared to the vehicle control group (Table 2; Figure 2; Appendix F). No chemical-related clinical findings were observed.

At study termination, absolute and relative spleen weights of the 3,10 , and $25 \mathrm{mg} / \mathrm{kg} /$ day groups, liver weights of the 10 and $25 \mathrm{mg} / \mathrm{kg} /$ day groups, and lung weights of the $25 \mathrm{mg} / \mathrm{kg} /$ day group were significantly increased compared to those of the vehicle control group; the absolute kidney weight of the $25 \mathrm{mg} / \mathrm{kg}$ /day group was also significantly increased (Table 3; Appendix F). No significant differences in ovary, thymus, or thyroid gland weight occurred in any dosed group compared to the vehicle control group.

Table 2. Summary of Survival and Mean Body Weights for Core Study Female Rats in the Three-month Gavage Study of Hexachlorobenzene ${ }^{a, b}$

\begin{tabular}{cccccc}
\hline $\begin{array}{c}\text { Dose } \\
(\mathbf{m g} / \mathbf{k g} / \text { day })\end{array}$ & Survival & $\begin{array}{c}\text { Initial Body } \\
\text { Weight }(\mathbf{g})\end{array}$ & $\begin{array}{c}\text { Final Body } \\
\text { Weight }(\mathbf{g})^{\mathbf{d}}\end{array}$ & $\begin{array}{c}\text { Change in Body } \\
\text { Weight (g) }\end{array}$ & $\begin{array}{c}\text { Final Weight } \\
\text { Relative to } \\
\text { Controls (\%) }\end{array}$ \\
\hline 0 & $10 / 10$ & $181.1 \pm 2.4$ & $264.3 \pm 4.6^{* *}$ & $83.3 \pm 3.3^{* *}$ & - \\
0.03 & $9 / 10^{\mathrm{e}}$ & $183.5 \pm 1.8$ & $259.7 \pm 5.9$ & $76.9 \pm 4.4$ & -1.77 \\
0.1 & $10 / 10$ & $181.0 \pm 2.5$ & $253.8 \pm 3.1$ & $72.8 \pm 3.9$ & -4.00 \\
0.3 & $10 / 10$ & $182.8 \pm 1.9$ & $257.3 \pm 5.2$ & $74.5 \pm 4.2$ & -2.66 \\
1 & $10 / 10$ & $183.8 \pm 2.5$ & $264.8 \pm 2.6$ & $81.0 \pm 2.8$ & 0.16 \\
3 & $10 / 10$ & $183.4 \pm 2.6$ & $273.2 \pm 4.7$ & $89.8 \pm 4.0$ & 3.34 \\
10 & $10 / 10$ & $179.9 \pm 2.3$ & $278.3 \pm 7.5$ & $98.4 \pm 6.2 *$ & 5.28 \\
25 & $10 / 10$ & $181.3 \pm 1.6$ & $293.6 \pm 6.0^{* *}$ & $112.3 \pm 5.4^{* *}$ & 11.08 \\
\hline
\end{tabular}

Statistical significance for a dosed group indicates a significant pairwise test compared to the vehicle control group. Statistical significance for the vehicle control group indicates a significant trend test.

*Statistically significant at $\mathrm{p} \leq 0.05 ; * \mathrm{p} \leq 0.01$.

${ }^{a}$ Weights and weight changes are given as mean \pm standard error.

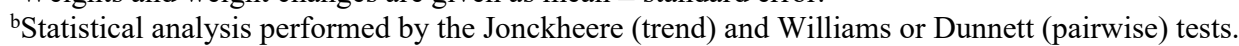

'Number of animals surviving at 3 months/number initially in group.

${ }^{\mathrm{d} B o d y}$ weight at necropsy.

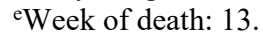




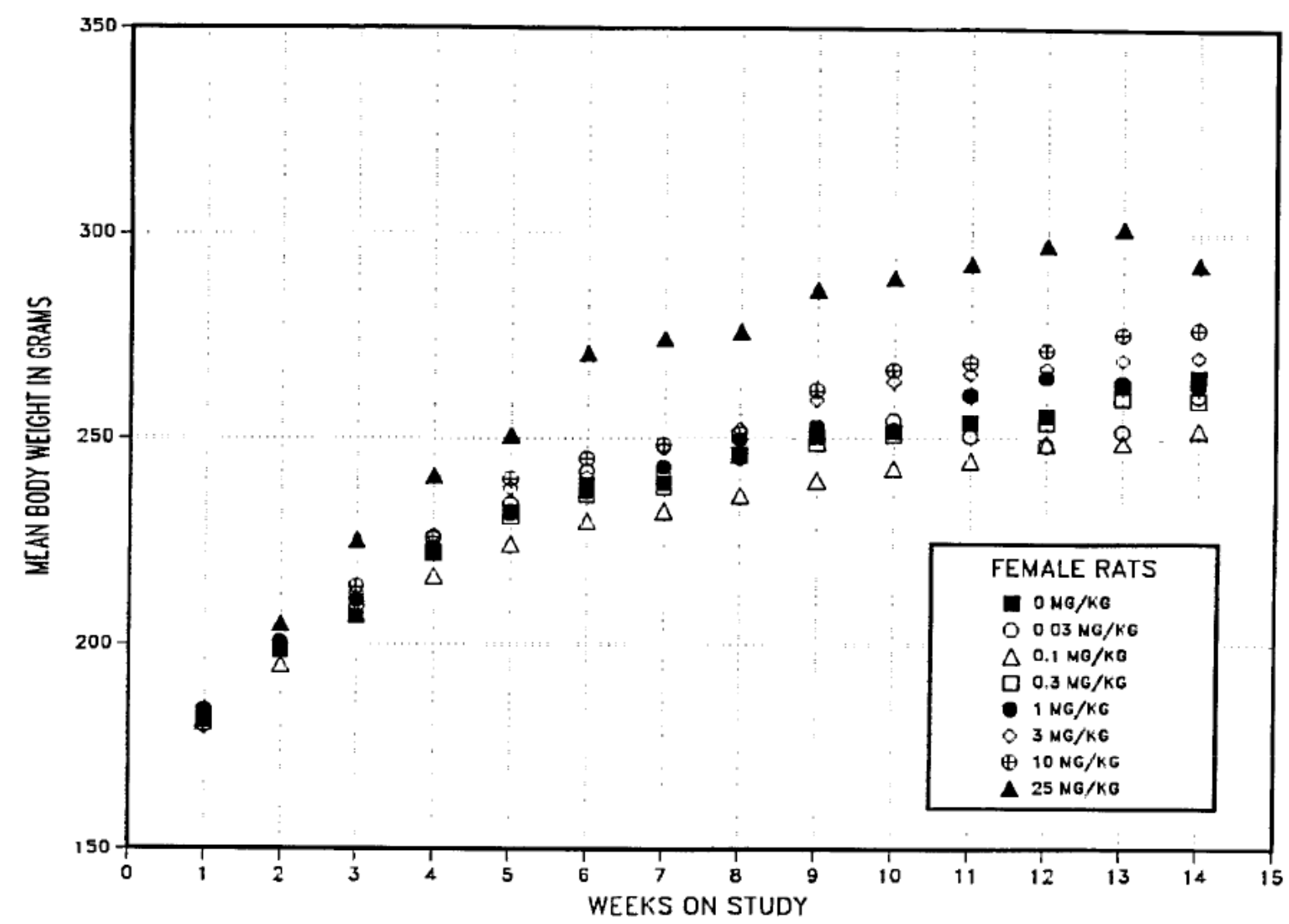

Figure 2. Growth Curves for Core Study Female Rats Administered Hexachlorobenzene by Gavage for Three Months

Total triiodothyronine ( $\mathrm{T}_{3}$ ) was significantly decreased by 1.7 -fold in the $25 \mathrm{mg} / \mathrm{kg} /$ day group compared to the vehicle control group (Table 4; Appendix F). Total thyroxine $\left(\mathrm{T}_{4}\right)$ and free $\mathrm{T}_{4}$ were significantly decreased in the 10 and $25 \mathrm{mg} / \mathrm{kg} /$ day groups compared to the vehicle control group. No significant differences in thyroid stimulating hormone (TSH) were observed in any dosed group compared to the vehicle control group.

No significant pairwise differences in hepatocyte proliferation were observed between dosed groups and the vehicle control group (Table 5; Appendix F). A significant positive trend was observed, and the labeling index in the 10 and $25 \mathrm{mg} / \mathrm{kg}$ /day groups was approximately twofold higher than that in the vehicle control group. 
Table 3. Summary of Select Organ Weights and Organ-Weight-to-Body-Weight Ratios for Core Study Female Rats in the Three-month Gavage Study of Hexachlorobenzene $e^{a, b}$

\begin{tabular}{|c|c|c|c|c|c|c|c|c|}
\hline & 0 mg/kg/day & $0.03 \mathrm{mg} / \mathrm{kg} / \mathrm{day}$ & $0.1 \mathrm{mg} / \mathrm{kg} / \mathrm{day}$ & $0.3 \mathrm{mg} / \mathrm{kg} / \mathrm{day}$ & $1 \mathrm{mg} / \mathrm{kg} / \mathrm{day}$ & $3 \mathrm{mg} / \mathrm{kg} / \mathrm{day}$ & $10 \mathrm{mg} / \mathrm{kg} / \mathrm{day}$ & $25 \mathrm{mg} / \mathrm{kg} / \mathrm{day}$ \\
\hline $\mathbf{n}$ & 10 & 9 & 10 & 10 & 10 & 10 & 10 & 10 \\
\hline Necropsy Body Wt. (g) & $264.3 \pm 4.6^{* *}$ & $259.7 \pm 5.9$ & $253.8 \pm 3.1$ & $257.3 \pm 5.2$ & $264.8 \pm 2.6$ & $273.2 \pm 4.7$ & $278.3 \pm 7.5$ & $293.6 \pm 6.0^{* *}$ \\
\hline \multicolumn{9}{|l|}{ Right Kidney } \\
\hline Absolute (g) & $0.73 \pm 0.02 * *$ & $0.74 \pm 0.02$ & $0.72 \pm 0.01$ & $0.74 \pm 0.03$ & $0.74 \pm 0.01$ & $0.75 \pm 0.02$ & $0.78 \pm 0.02$ & $0.86 \pm 0.02 * *$ \\
\hline Relative (mg/g) & $2.75 \pm 0.06$ & $2.84 \pm 0.06$ & $2.82 \pm 0.02$ & $2.88 \pm 0.07$ & $2.80 \pm 0.04$ & $2.75 \pm 0.06$ & $2.80 \pm 0.05$ & $2.92 \pm 0.06$ \\
\hline \multicolumn{9}{|l|}{ Liver } \\
\hline Absolute (g) & $8.32 \pm 0.21^{* *}$ & $7.64 \pm 0.25$ & $7.75 \pm 0.20$ & $7.91 \pm 0.30$ & $8.22 \pm 0.20$ & $8.89 \pm 0.21$ & $10.28 \pm 0.47 * *$ & $12.53 \pm 0.41 * *$ \\
\hline Relative (mg/g) & $31.47 \pm 0.54 * *$ & $29.40 \pm 0.54$ & $30.51 \pm 0.64$ & $30.68 \pm 0.63$ & $31.01 \pm 0.59$ & $32.54 \pm 0.58$ & $36.83 \pm 0.88^{* *}$ & $42.82 \pm 1.68 * *$ \\
\hline \multicolumn{9}{|l|}{ Lung } \\
\hline Absolute (g) & $1.58 \pm 0.08 * *$ & $1.54 \pm 0.05$ & $1.54 \pm 0.03$ & $1.56 \pm 0.06$ & $1.56 \pm 0.07$ & $1.70 \pm 0.07$ & $1.70 \pm 0.08$ & $2.08 \pm 0.08 * *$ \\
\hline Relative (mg/g) & $5.95 \pm 0.22 * *$ & $5.93 \pm 0.13$ & $6.09 \pm 0.12$ & $6.05 \pm 0.18$ & $5.90 \pm 0.26$ & $6.20 \pm 0.20$ & $6.09 \pm 0.22$ & $7.10 \pm 0.22 * *$ \\
\hline \multicolumn{9}{|l|}{ Spleen } \\
\hline Absolute (mg) & $576 \pm 20 * *$ & $587 \pm 14$ & $565 \pm 20$ & $590 \pm 31$ & $566 \pm 12$ & $666 \pm 19 * *$ & $689 \pm 26^{* *}$ & $952 \pm 29 * *$ \\
\hline Relative (mg/g) & $2.17 \pm 0.05^{* *}$ & $2.27 \pm 0.05$ & $2.23 \pm 0.07$ & $2.28 \pm 0.09$ & $2.14 \pm 0.04$ & $2.44 \pm 0.06^{* *}$ & $2.47 \pm 0.06^{* *}$ & $3.24 \pm 0.09 * *$ \\
\hline
\end{tabular}


Table 4. Summary of Serum Concentrations of Thyroid Hormones for Core Study Female Rats in the Three-month Gavage Study of Hexachlorobenzene ${ }^{a, b}$

\begin{tabular}{|c|c|c|c|c|c|c|c|c|}
\hline & $0 \mathrm{mg} / \mathrm{kg} / \mathrm{day}$ & $0.03 \mathrm{mg} / \mathrm{kg} / \mathrm{day}$ & $0.1 \mathrm{mg} / \mathrm{kg} / \mathrm{day}$ & $0.3 \mathrm{mg} / \mathrm{kg} / \mathrm{day}$ & $1 \mathrm{mg} / \mathrm{kg} / \mathrm{day}$ & $3 \mathrm{mg} / \mathrm{kg} / \mathrm{day}$ & $10 \mathrm{mg} / \mathrm{kg} / \mathrm{day}$ & $25 \mathrm{mg} / \mathrm{kg} / \mathrm{day}$ \\
\hline n & 10 & 9 & 10 & 10 & 10 & 10 & 10 & 10 \\
\hline $\mathrm{T}_{3}(\mathrm{ng} / \mathrm{dL})$ & $155.000 \pm 12.189 * *$ & $138.867 \pm 8.791$ & $132.140 \pm 9.665$ & $157.130 \pm 11.718$ & $130.540 \pm 10.972$ & $144.150 \pm 13.213$ & $131.670 \pm 4.759$ & $93.630 \pm 6.367 * *$ \\
\hline Total $\mathrm{T}_{4}(\mu \mathrm{g} / \mathrm{dL})$ & $5.43 \pm 0.31 * *$ & $6.73 \pm 0.38$ & $5.70 \pm 0.35$ & $5.99 \pm 0.42$ & $5.44 \pm 0.31$ & $4.77 \pm 0.38$ & $2.03 \pm 0.36^{* *}$ & $0.04 \pm 0.04^{* *}$ \\
\hline Free $\mathrm{T}_{4}(\mathrm{ng} / \mathrm{dL})$ & $2.983 \pm 0.107 * *$ & $3.35 \pm 0.200$ & $3.046 \pm 0.321$ & $2.891 \pm 0.260$ & $2.470 \pm 0.152$ & $2.430 \pm 0.205$ & $1.455 \pm 0.124^{* *}$ & $0.536 \pm 0.039 * *$ \\
\hline TSH (ng/mL) & $10.450 \pm 0.864$ & $10.200 \pm 1.018$ & $11.430 \pm 1.183$ & $10.890 \pm 0.569$ & $11.710 \pm 1.361$ & $11.230 \pm 0.604$ & $10.550 \pm 1.163$ & $10.680 \pm 1.069$ \\
\hline
\end{tabular}

Statistical significance for a dosed group indicates a significant pairwise test compared to the vehicle control group. Statistical significance for the vehicle control group indicates a significant trend test.

$* *$ Statistically significant at $\mathrm{p} \leq 0.01$.

$\mathrm{T}_{3}=$ triiodothyronine; $\mathrm{T}_{4}=$ thyroxine; $\mathrm{TSH}=$ thyroid stimulating hormone.

${ }^{\text {aD }}$ ata are presented as mean \pm standard error.

${ }^{b}$ Statistical analysis performed by the Jonckheere (trend) and Shirley or Dunn (pairwise) tests.

Table 5. Summary of Hepatic Cell Proliferation Data for Core Study Female Rats in the Three-month Gavage Study of Hexachlorobenzene ${ }^{a, b}$

\begin{tabular}{|c|c|c|c|c|c|c|c|c|}
\hline & $0 \mathrm{mg} / \mathrm{kg} / \mathrm{day}$ & $0.03 \mathrm{mg} / \mathrm{kg} / \mathrm{day}$ & $0.1 \mathrm{mg} / \mathrm{kg} / \mathrm{day}$ & $0.3 \mathrm{mg} / \mathrm{kg} / \mathrm{day}$ & $1 \mathrm{mg} / \mathrm{kg} / \mathrm{day}$ & $3 \mathrm{mg} / \mathrm{kg} / \mathrm{day}$ & $10 \mathrm{mg} / \mathrm{kg} / \mathrm{day}$ & $25 \mathrm{mg} / \mathrm{kg} / \mathrm{day}$ \\
\hline $\mathbf{n}$ & 10 & 9 & 10 & 10 & 10 & 10 & 10 & 10 \\
\hline Total Cells Counted & $2,202 \pm 39$ & $2,231 \pm 46$ & $2,221 \pm 36$ & $2,205 \pm 26$ & $2,184 \pm 33$ & $2,215 \pm 29$ & $2,128 \pm 24$ & $2,171 \pm 28$ \\
\hline Total Labeled Cells & $36 \pm 5^{*}$ & $30 \pm 8$ & $28 \pm 5$ & $22 \pm 6$ & $18 \pm 3$ & $23 \pm 2$ & $67 \pm 21$ & $75 \pm 12$ \\
\hline Labeling Index (\%) & $1.63 \pm 0.24^{*}$ & $1.35 \pm 0.35$ & $1.25 \pm 0.24$ & $0.98 \pm 0.29$ & $0.85 \pm 0.14$ & $1.05 \pm 0.08$ & $3.16 \pm 1.02$ & $3.45 \pm 0.52$ \\
\hline
\end{tabular}

Statistical significance for the vehicle control group indicates a significant trend test.

* Statistically significant at $\mathrm{p} \leq 0.05$.

aData are presented as mean \pm standard error.

${ }^{b}$ Differences from the vehicle control group are not significant by the Dunn test. 
Hepatic acetanilide-4-hydroxylase (A4H) was significantly increased in all dosed groups at week 14 (core study rats) compared to the vehicle control group, with a maximal induction of $3.6-$ fold at $3 \mathrm{mg} / \mathrm{kg} /$ day (Table 6; Appendix F). A4H activity in the 10 and $25 \mathrm{mg} / \mathrm{kg} /$ day groups was less than that in the $3 \mathrm{mg} / \mathrm{kg}$ /day group. Hepatic pentoxyresorufin- $O$-deethylase (PROD) activity was significantly increased in all dosed groups at week 14 compared to the vehicle control group, with a maximal induction of 37.5 -fold at $3 \mathrm{mg} / \mathrm{kg} /$ day (Table 6; Appendix F). In the 10 and $25 \mathrm{mg} / \mathrm{kg}$ /day groups, PROD activity decreased in a dose-dependent manner compared to the $3 \mathrm{mg} / \mathrm{kg}$ /day group. 7-Ethoxyresorufin- $O$-deethylase (EROD) activity was higher in all dosed groups compared to the vehicle control group, reaching statistical significance in the $\geq 0.3 \mathrm{mg} / \mathrm{kg} /$ day dosed groups, and continued to increase up to 9.5 -fold in the $25 \mathrm{mg} / \mathrm{kg}$ /day group (Table 6; Appendix F).

Pulmonary EROD activity was significantly increased (7.8-fold from vehicle control animals) only at week 14 in rats administered $25 \mathrm{mg} / \mathrm{kg} /$ day HCB (Table 7; Appendix F). Pulmonary PROD and A4H activities were not evaluated.

\section{Hexachlorobenzene Concentrations in Blood and Tissues}

Concentrations of HCB were determined in blood, liver, lung, and adipose tissue after dosing for 3 months (Table 8; Appendix F). The limit of detection of HCB was $2.2 \mathrm{ng} / \mathrm{mL}, 0.24 \mathrm{ng} / \mathrm{g}$, $0.91 \mathrm{ng} / \mathrm{g}$, and $0.88 \mathrm{ng} / \mathrm{g}$ in blood, liver, lung, and adipose tissue, respectively. HCB was detected in all tissues of vehicle control animals but was below the limit of detection in the blood for 6 of 10 samples. Concentrations of HCB in blood and tissues increased generally in proportion to dose. The highest concentrations of HCB were found in the adipose tissue, followed by the liver; concentrations in the lung and blood were similar to each other. Concentrations of HCB in the adipose tissue were 41- to 64-fold higher than concentrations of HCB in the blood. Liver HCB concentrations were 1.8- to 3.1-fold higher than blood HCB concentrations. Lung HCB concentrations were 2.4-fold and 4.3-fold higher than blood concentrations for the 0.03 and $0.1 \mathrm{mg} / \mathrm{kg} /$ day groups, respectively; concentrations were approximately equivalent (approximately onefold) for doses $\geq 0.3 \mathrm{mg} / \mathrm{kg} / \mathrm{day}$. The fold difference between HCB concentrations in tissues compared to blood tended to decrease with increasing dose. 
Table 6. Summary of Hepatic Cytochrome P450 Data for Female Rats in the Gavage Studies of Hexachlorobenzene ${ }^{a, b}$

\begin{tabular}{|c|c|c|c|c|c|c|c|c|}
\hline & $0 \mathrm{mg} / \mathrm{kg} / \mathrm{day}$ & $0.03 \mathrm{mg} / \mathrm{kg} / \mathrm{day}$ & $0.1 \mathrm{mg} / \mathrm{kg} / \mathrm{day}$ & $0.3 \mathrm{mg} / \mathrm{kg} / \mathrm{day}$ & $1 \mathrm{mg} / \mathrm{kg} / \mathrm{day}$ & $3 \mathrm{mg} / \mathrm{kg} / \mathrm{day}$ & $10 \mathrm{mg} / \mathrm{kg} / \mathrm{day}$ & $25 \mathrm{mg} / \mathrm{kg} /$ \\
\hline \multicolumn{9}{|l|}{$\mathbf{n}$} \\
\hline Week 14 & 10 & 9 & 10 & 10 & 10 & 10 & 10 & 10 \\
\hline Week 21 & 5 & 5 & $-^{\mathrm{c}}$ & - & - & - & - & 5 \\
\hline Week 29 & 5 & 5 & - & - & - & - & - & 5 \\
\hline
\end{tabular}

\section{A4H (nmol/minute/mg protein)}

\begin{tabular}{|c|c|c|c|c|c|c|c|c|}
\hline Week 14 & $0.465 \pm 0.028 * *$ & $0.560 \pm 0.030^{*}$ & $0.524 \pm 0.020^{*}$ & $0.626 \pm 0.019 * *$ & $0.978 \pm 0.042 * *$ & $1.669 \pm 0.090^{* *}$ & $0.965 \pm 0.182 * *$ & $0.691 \pm 0.169 * *$ \\
\hline Week 21 & $0.354 \pm 0.018 * *$ & $0.286 \pm 0.025$ & - & - & - & - & - & $0.173 \pm 0.018^{* *}$ \\
\hline Week 29 & $0.285 \pm 0.041$ & $0.256 \pm 0.041$ & - & - & - & - & - & $0.313 \pm 0.039$ \\
\hline \multicolumn{9}{|c|}{ EROD (pmol/minute/mg protein) } \\
\hline Week 14 & $35.9 \pm 4.1 * *$ & $43.0 \pm 2.8$ & $42.4 \pm 1.9$ & $48.1 \pm 3.8 * *$ & $107.7 \pm 5.9 * *$ & $284.2 \pm 23.0^{* *}$ & $314.1 \pm 52.3 * *$ & $339.7 \pm 67.7 * *$ \\
\hline Week 21 & $26.9 \pm 1.9$ & $20.3 \pm 2.0$ & - & - & - & - & - & $71.7 \pm 11.7$ \\
\hline Week 29 & $24.1 \pm 3.7^{* *}$ & $27.0 \pm 3.0$ & - & - & - & - & - & $67.8 \pm 7.6^{* *}$ \\
\hline \multicolumn{9}{|c|}{ PROD (pmol/minute/mg protein) ${ }^{\mathrm{d}}$} \\
\hline Week 14 & $1.77 \pm 0.14 * *$ & $2.94 \pm 0.11^{* *}$ & $4.39 \pm 0.22 * *$ & $9.07 \pm 0.65^{* *}$ & $21.71 \pm 0.98^{* *}$ & $66.30 \pm 4.57 * *$ & $38.94 \pm 5.41 * *$ & $28.19 \pm 2.63 * *$ \\
\hline \multicolumn{9}{|c|}{$\begin{array}{l}\text { Statistical significance for a dosed group indicates a significant pairwise test compared to the vehicle control group. Statistical significance for the vehicle control group indicates a } \\
\text { significant trend test. } \\
* \text { Statistically significant at } \mathrm{p} \leq 0.05 ; * \mathrm{p} \leq 0.01 \text {. } \\
\text { A4H }=\text { acetanilide-4-hydroxylase; EROD }=7 \text {-ethoxyresorufin- } O \text {-deethylase; PROD }=\text { pentoxyresorufin- } O \text {-deethylase. } \\
\text { aData are presented as mean } \pm \text { standard error. Core study rats were necropsied at } 3 \text { months (week } 14 \text { ); elimination study rats were necropsied at week } 21 \text { or at week } 29 \text {. } \\
\text { bStatistical analysis performed by the Jonckheere (trend) and Shirley or Dunn (pairwise) tests. } \\
\text { cNot applicable. } \\
\text { dPROD activity was assayed only at week } 14 \text {. }\end{array}$} \\
\hline
\end{tabular}


Table 7. Summary of Pulmonary 7-Ethoxyresorufin-O-deethylase Activity for Female Rats in the Gavage Studies of Hexachlorobenzene ${ }^{\text {a,b }}$

\begin{tabular}{llllllll}
\hline $0 \mathrm{mg} / \mathrm{kg} / \mathrm{day}$ & $0.03 \mathrm{mg} / \mathrm{kg} / \mathrm{day}$ & $0.1 \mathrm{mg} / \mathrm{kg} / \mathrm{day}$ & $0.3 \mathrm{mg} / \mathrm{kg} / \mathrm{day}$ & $1 \mathrm{mg} / \mathrm{kg} / \mathrm{day}$ & $3 \mathrm{mg} / \mathrm{kg} / \mathrm{day}$ & $10 \mathrm{mg} / \mathrm{kg} / \mathrm{day}$ & $25 \mathrm{mg} / \mathrm{kg} / \mathrm{day}$ \\
\hline
\end{tabular}

n

Week 21

10

9

9

10

10

10

10

$10 \quad 10$

Week 29

5

5

EROD (pmol/minute/mg protein)

Week $14 \quad 0.628 \pm 0.110^{* *}$ $0.958 \pm 0.229 \quad 0.538 \pm 0.067$

$0.621 \pm 0.082$

$0.885 \pm 0.136$

$0.338 \pm 0.063$

$0.843 \pm 0.100 \quad 4.872 \pm 0.903 * *$

Week 21

Statistical significance for a dosed group indicates a significant pairwise test compared to the vehicle control group. Statistical significance for the vehicle control group indicates a significant trend test.

$* *$ Statistically significant at $\mathrm{p} \leq 0.01$.

EROD $=7$-ethoxyresorufin- $O$-deethylase.

${ }^{\text {aD }}$ ata are presented as mean \pm standard error. Core study rats were necropsied at 3 months (week 14); elimination study rats were necropsied at week 21 or at week 29 .

bStatistical analysis performed by the Jonckheere (trend) and Shirley or Dunn (pairwise) tests.

'Not applicable.

dEROD measurements were below the limit of detection. 
Table 8. Summary of Concentrations of Hexachlorobenzene in Blood and Tissues for Core Study Female Rats in the Three-month Gavage Study of Hexachlorobenzene $\mathrm{e}^{\mathrm{a}, \mathrm{b}}$

\begin{tabular}{|c|c|c|c|c|c|c|c|c|}
\hline & 0 mg/kg/day & $0.03 \mathrm{mg} / \mathrm{kg} / \mathrm{day}$ & $0.1 \mathrm{mg} / \mathrm{kg} / \mathrm{day}$ & $0.3 \mathrm{mg} / \mathrm{kg} / \mathrm{day}$ & $1 \mathrm{mg} / \mathrm{kg} / \mathrm{day}$ & $3 \mathrm{mg} / \mathrm{kg} / \mathrm{day}$ & $10 \mathrm{mg} / \mathrm{kg} / \mathrm{day}$ & $25 \mathrm{mg} / \mathrm{kg} / \mathrm{day}$ \\
\hline \multicolumn{9}{|l|}{$\mathbf{n}$} \\
\hline Blood & 10 & 9 & 10 & 10 & 10 & 10 & 10 & $8^{c}$ \\
\hline Liver & $9^{d}$ & 9 & 10 & 10 & 10 & 10 & 10 & 10 \\
\hline Lung & 10 & 9 & 10 & 10 & 10 & 10 & 10 & 10 \\
\hline Adipose & 10 & 9 & 10 & 10 & 10 & 10 & 10 & 10 \\
\hline \multicolumn{9}{|c|}{ Tissue Hexachlorobenzene Concentration } \\
\hline Blood (ng/mL) & $1.88 \pm 0.362 * * \mathrm{e}$ & $144 \pm 5.11 * *$ & $451 \pm 18.4 * *$ & $1,350 \pm 68.2 * *$ & $5,050 \pm 277^{* *}$ & $15,400 \pm 620 * *$ & $50,400 \pm 1,840 * *$ & $152,200 \pm 7,070^{* *}$ \\
\hline Liver (ng/g) & $27.0 \pm 1.74 * *$ & $422 \pm 38.0^{* *}$ & $1,120 \pm 75.9^{* *}$ & $4,140 \pm 225^{* *}$ & $11,800 \pm 486^{* *}$ & $37,700 \pm 1,400^{* *}$ & $119,000 \pm 5,420 * *$ & $270,000 \pm 15,700 * *$ \\
\hline Lung (ng/g) & $196 \pm 56.5^{* *}$ & $342 \pm 53.5$ & $1,960 \pm 487^{* *}$ & $1,830 \pm 166^{* *}$ & $4,640 \pm 338^{* *}$ & $22,000 \pm 2,510^{* *}$ & $73,200 \pm 12,800 * *$ & $150,000 \pm 15,300 * *$ \\
\hline Adipose $(\mu \mathrm{g} / \mathrm{g})$ & $0.627 \pm 0.0761^{* *}$ & $9.24 \pm 0.450^{* *}$ & $25.2 \pm 1.36^{* *}$ & $65.9 \pm 2.93 * *$ & $251 \pm 8.65^{* *}$ & $766 \pm 29.8^{* *}$ & $2,380 \pm 98.8^{* *}$ & $6,260 \pm 181^{* *}$ \\
\hline
\end{tabular}

Statistical significance for a dosed group indicates a significant pairwise test compared to the vehicle control group. Statistical significance for the vehicle control group indicates a significant trend test.

$* *$ Statistically significant at $\mathrm{p} \leq 0.01$.

a Data shown as mean \pm standard error.

bStatistical analysis performed by the Jonckheere (trend) and Shirley or Dunn (pairwise) tests.

'Sample volume was not sufficient for analysis.

${ }^{\mathrm{d}}$ One value was excluded as an outlier.

eOf 10 samples, 6 were below the limit of detection (LOD) of $2.2 \mathrm{ng} / \mathrm{mL}$. Because $20 \%$ of the animals in this group were above the LOD, one-half the LOD value (1.1 $\mathrm{ng} / \mathrm{mL}$ ) was substituted for values that were below the LOD. 


\section{Pathology}

This section describes the statistically significant or biologically noteworthy changes in the incidences of nonneoplastic lesions of the liver, lung, spleen, mammary gland, skin, thymus, and teeth. Summaries of the incidences of nonneoplastic lesions and statistical analyses of primary nonneoplastic lesions are presented in Appendix F. Average severity grades of 1 for minimal, 2 for mild, 3 for moderate, and 4 for marked were used in affected animals.

Liver: There was a significant increase in the incidences of hepatocyte hypertrophy in the 10 and $25 \mathrm{mg} / \mathrm{kg}$ /day groups compared to the vehicle control group (Table 9). Hepatocyte hypertrophy was diagnosed when hepatocytes (generally centrilobular) were enlarged and had pale eosinophilic cytoplasm. The cytoplasm was increasingly clear with increased enlargement. Hepatocyte nuclei were normal in size, although more bi- and trinucleated hepatocytes were noted in affected livers. Dose-related increases in liver weights were attributed to hepatocellular hypertrophy.

Lung: There was a significant increase in the incidences of pulmonary chronic inflammation in the 3,10 , and $25 \mathrm{mg} / \mathrm{kg} /$ day groups compared to the vehicle control group (Table 9). Chronic inflammation consisted of mixed cellular infiltrates composed of mononuclear cell infiltration characterized by the presence of mononuclear cells (largely lymphocytic), fewer plasma cells within the interstitium, and macrophages within the alveoli. Chronic inflammation might have contributed to the increased lung weights.

Spleen: There was a significant increase in the incidences of splenic lymphoid hyperplasia in the 10 and $25 \mathrm{mg} / \mathrm{kg}$ /day dosed groups compared to the vehicle control group (Table 9). Splenic lymphoid hyperplasia was characterized by an increase in thickness of the marginal zone of lymphoid follicles, relative to the follicle center.

Mammary gland: There was a significant increase in the incidences of mammary gland hyperplasia in the $25 \mathrm{mg} / \mathrm{kg}$ /day group compared to the vehicle control group (Table 9). Hyperplasia of the alveoli is defined as a relative increase of tubuloalveolar patterns of growth, characterized by alveoli with or without vacuoles within the alveolar epithelium and attached to or close to branched, linear arrays of hypertrophied ducts. The severity was graded as mild if there was evidence of secretion within the hyperplastic glands.

Skin: There was a significant increase in the incidences of skin ulceration and suppurative inflammation in the $25 \mathrm{mg} / \mathrm{kg}$ /day group compared to the vehicle control group (Table 9). These lesions correlated with the grossly observed crusts affecting the skin of the face and head.

Thymus: Thymic atrophy was noted in 1 animal in the $0.03 \mathrm{mg} / \mathrm{kg} /$ day group and in 3 of 10 animals in the $25 \mathrm{mg} / \mathrm{kg}$ /day group (Table 9). Thymic atrophy was characterized by reduced density of lymphocytes in the thymic cortex or when foci were found within the thymus in which the cortex and medulla were reduced, as well as when the epithelial component(s) were more prominent. The animal in the $0.03 \mathrm{mg} / \mathrm{kg} /$ day group was euthanized moribund, and the thymic atrophy was determined to be secondary to the stress of the mammary neoplasia observed upon necropsy. There were no significant differences in thymus weight in dosed groups compared to the vehicle control group. The three animals in the $25 \mathrm{mg} / \mathrm{kg} /$ day group did not have notably smaller thymuses. 
Teeth: There was a significant increase in the incidences of region-specific unilaterally or bilaterally symmetrical (when present) maxillary incisor degeneration in the $\geq 1 \mathrm{mg} / \mathrm{kg}$ groups compared to the vehicle control group (Table 9). The molars were unaffected by exposure. ${ }^{130}$ The number of animals affected and the severity of the maxillary incisor degeneration increased in a dose-dependent manner.

The grading scheme used for maxillary incisor degeneration was as follows. Incisor degeneration was graded on a scale of $0-4$, with 0 representing no lesion, 1 representing minimal degeneration, 2 representing mild degeneration, 3 representing moderate degeneration, and 4 representing severe degeneration.

- Grade 0 (no lesion) normal incisor was characterized by having no significant microscopic lesions.

- Grade 1 (minimal) incisor degeneration was characterized by focal pulp alteration.

- Grade 2 (mild) incisor degeneration was characterized by focal or multifocal pulp alteration with focal odontoblast degeneration.

- Grade 3 (moderate) incisor degeneration was characterized by multifocal pulp alteration and multifocal odontoblast degeneration.

- Grade 4 (severe) incisor degeneration was characterized by multifocal pulp alteration, multifocal odontoblast degeneration, and complete discontinuities in the dentin surrounding the pulp chamber.

Administration of $1 \mathrm{mg} / \mathrm{kg} /$ day HCB resulted in focal mesenchymal cell vacuolation and focal osteodentin formation within the pulp (Figure 3). Lesions were restricted to a short linear region subjacent to the odontoblast layer along the lateral aspect of the incisor at the level of the dentinenamel interface. When observed in both incisors, lesions were bilaterally symmetrical. Administration of $3 \mathrm{mg} / \mathrm{kg} /$ day resulted in lateral and medial pulp lesions and focal odontoblast degeneration with dentin niche formation along the lateral incisor margin in some animals. Administration of $10 \mathrm{mg} / \mathrm{kg} /$ day resulted in a higher incidence of lateral dentin niches and a lower incidence of medial dentin niches (Figure 4). In animals administered $25 \mathrm{mg} / \mathrm{kg} /$ day HCB, a high incidence of bilaterally symmetrical, lateral and medial, dentin niches was observed (Figure 5). (Compare Figure 4 and Figure 5 with normal aspect in the vehicle control animal in Figure 6.) There was no evidence of hemorrhage, thrombosis, or vasculitis. 
Table 9. Incidences of Select Nonneoplastic Lesions in Core Study Female Rats in the Three-month Gavage Study of Hexachlorobenzene ${ }^{\text {a }}$

\begin{tabular}{|c|c|c|c|c|c|c|c|c|}
\hline & $0 \mathrm{mg} / \mathrm{kg} / \mathrm{day}$ & $0.03 \mathrm{mg} / \mathrm{kg} / \mathrm{day}$ & $0.1 \mathrm{mg} / \mathrm{kg} / \mathrm{day}$ & $0.3 \mathrm{mg} / \mathrm{kg} / \mathrm{day}$ & $1 \mathrm{mg} / \mathrm{kg} / \mathrm{day}$ & $3 \mathrm{mg} / \mathrm{kg} / \mathrm{day}$ & $10 \mathrm{mg} / \mathrm{kg} / \mathrm{day}$ & $25 \mathrm{mg} / \mathrm{kg} / \mathrm{day}$ \\
\hline $\mathbf{n}^{\mathrm{b}}$ & 10 & 10 & 10 & 10 & 10 & 10 & 10 & 10 \\
\hline \multicolumn{9}{|l|}{ Liver } \\
\hline Hepatocyte hypertrophy ${ }^{\mathrm{c}}$ & $0 * *$ & 0 & 0 & 0 & 0 & 0 & $9^{* *}(1.1)^{\mathrm{d}}$ & $10 * *(1.3)$ \\
\hline \multicolumn{9}{|l|}{ Lung } \\
\hline Inflammation, chronic & $3 * *(1.0)$ & $1(1.0)$ & $1(1.0)$ & $2(1.0)$ & $7(1.3)$ & $8 *(1.6)$ & $10 * *(1.7)$ & $10 * *(1.9)$ \\
\hline \multicolumn{9}{|l|}{ Spleen } \\
\hline Lymphoid hyperplasia & $0 * *$ & 0 & 0 & 0 & 0 & 0 & $6 * *(1.0)$ & $8 * *(1.0)$ \\
\hline \multicolumn{9}{|l|}{ Mammary Gland } \\
\hline Hyperplasia & $2 * *(1.0)$ & $2(2.0)$ & $1(1.0)$ & 0 & $2(1.0)$ & $2(1.0)$ & $3(1.3)$ & $10 * *(1.2)$ \\
\hline \multicolumn{9}{|l|}{ Skin } \\
\hline Inflammation, suppurative & $0 * *$ & 0 & $0^{\mathrm{e}}$ & 0 & 0 & $0^{\mathrm{e}}$ & 0 & $9 * *(2.4)$ \\
\hline Ulcer & $0 * *$ & 0 & $0^{\mathrm{e}}$ & 0 & 0 & $0^{\mathrm{e}}$ & 0 & $7 * *(1.6)$ \\
\hline \multicolumn{9}{|l|}{ Thymus } \\
\hline Atrophy & $0 * *$ & $1(4.0)^{\mathrm{f}}$ & 0 & 0 & 0 & 0 & 0 & $3(1.0)$ \\
\hline \multicolumn{9}{|l|}{ Teeth } \\
\hline $\begin{array}{l}\text { Maxillary incisor, } \\
\text { degeneration }\end{array}$ & $0 * *$ & 0 & 0 & 0 & $5^{*}(1.0)$ & $10 * *(1.5)$ & $10 * *(2.1)$ & $10 * *(2.9)$ \\
\hline $\begin{array}{l}\text { Statistical significance for a dosec } \\
\text { significant trend test. } \\
* \text { Statistically significant at } \mathrm{p} \leq 0.0 \\
\text { a Statistical analysis performed by } \\
\text { bNumber of animals examined mi } \\
\text { cNumber of animals with lesion. } \\
\text { d Average severity grade of lesions } \\
\text { e } n=9 \text {. }\end{array}$ & $\begin{array}{l}\text { oup indicates a si } \\
* * \mathrm{p} \leq 0.01 \\
\text { Cochran-Armita } \\
\text { scopically. } \\
\text { affected animals }\end{array}$ & $\begin{array}{l}\text { ignificant pairwise } t \\
\text { ge (trend) or Fisher } \\
1=\text { minimal, } 2=n\end{array}$ & $\begin{array}{l}\text { est compared to the } \\
\text { 's exact (pairwise) } \\
\text { nild, } 3 \text { = moderate, }\end{array}$ & $\begin{array}{l}\text { e vehicle control gr } \\
\text { test. } \\
4=\text { marked. }\end{array}$ & coup. Statistical & gnificance for & vehicle control & group indicates a \\
\hline
\end{tabular}




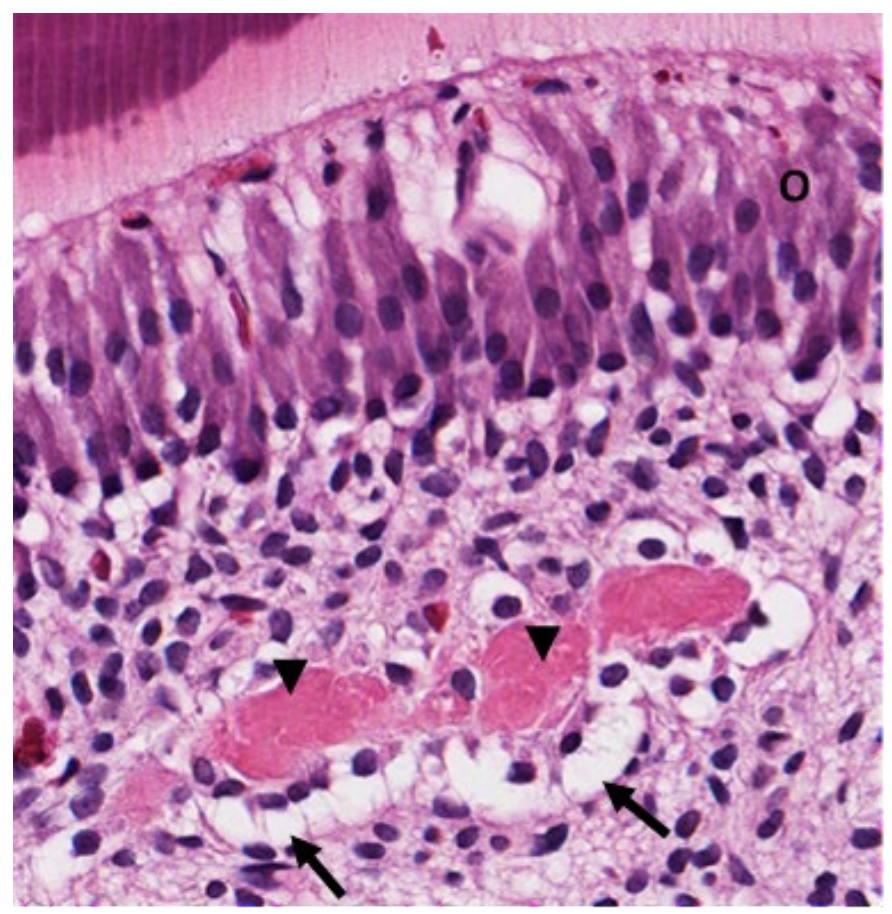

Figure 3. Level II Section of a Maxillary Incisor Tooth from a Female Rat Administered $1 \mathrm{mg} / \mathrm{kg} /$ day Hexachlorobenzene Showing Minimal Incisor Degeneration

Note vacuolation of pulp mesenchymal cells (arrows) and osteodentin formation (arrow heads). Odontoblasts (O) are unaffected.

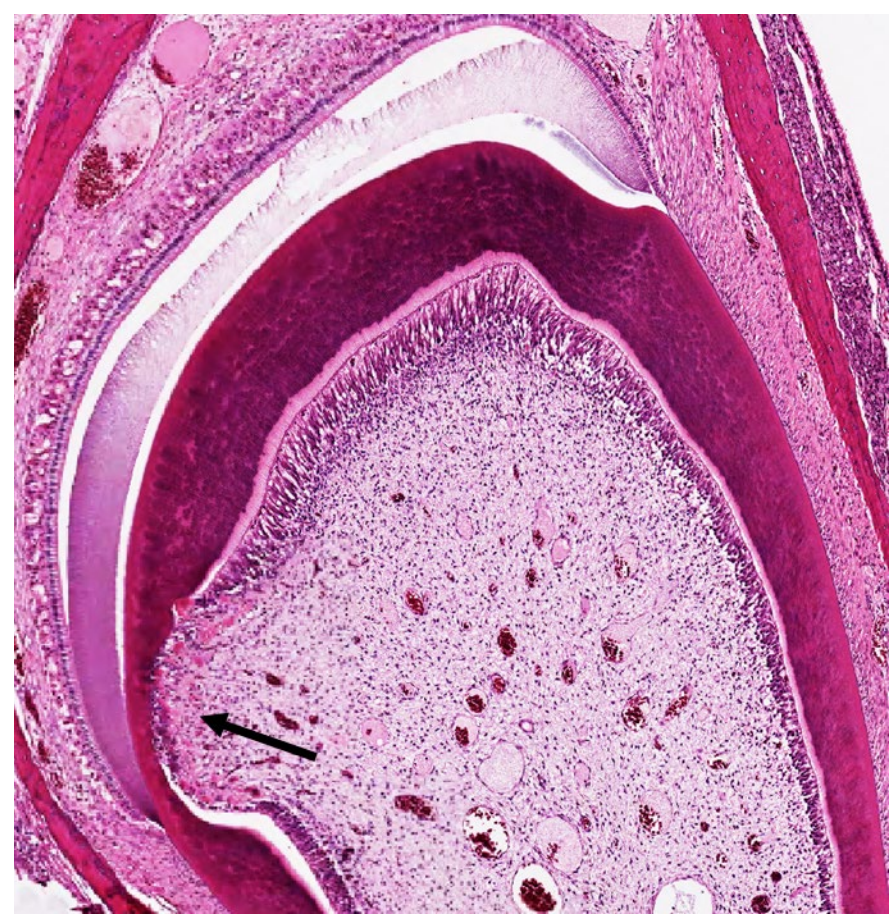

Figure 4. Level II Section of a Maxillary Incisor Tooth from a Female Rat Administered $10 \mathrm{mg} / \mathrm{kg} /$ day Hexachlorobenzene

Note mild degeneration in the maxillary incisor, characterized by focal pulp and odontoblast degeneration and formation of a dentin niche (arrow) along the lateral aspect of the maxillary incisor. 


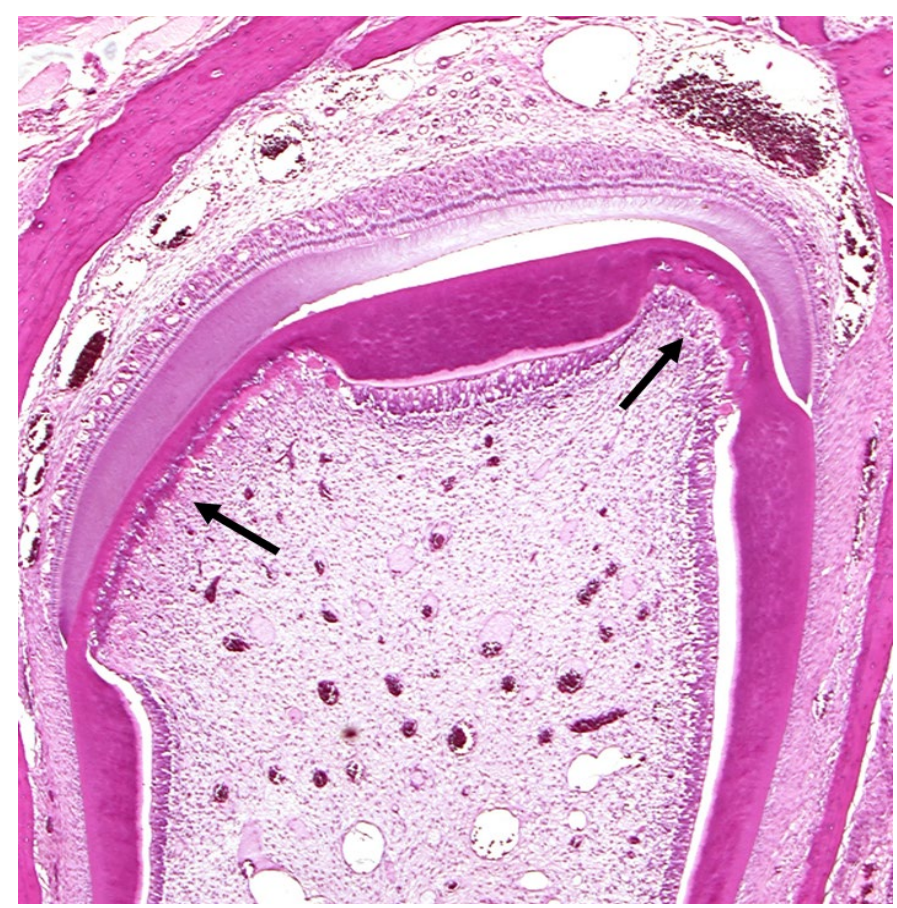

Figure 5. Level II Section of a Maxillary Incisor Tooth from a Female Rat Administered $25 \mathrm{mg} / \mathrm{kg} / \mathrm{day}$ Hexachlorobenzene

Note lateral (large) and medial (small) dentin niche defects (arrows) in maxillary incisor.

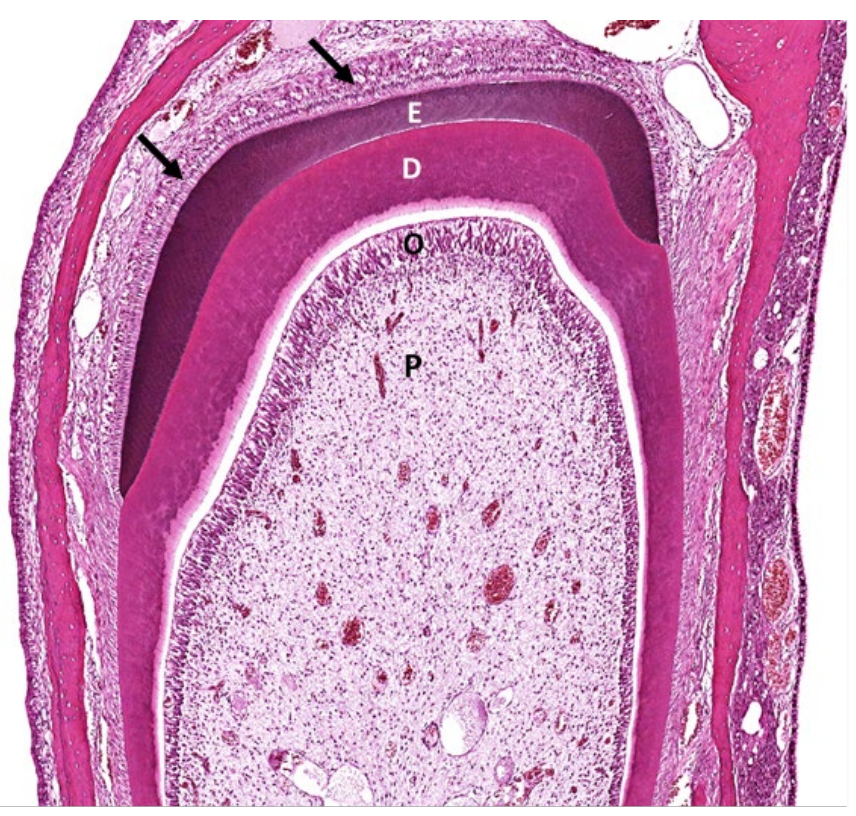

Figure 6. Level II Section of a Maxillary Incisor Tooth from a Vehicle Control Female Rat

Note pulp (P), odontoblasts (O), dentin (D), enamel (E), and ameloblasts (arrows). 


\section{Determination of Relative Potency Factors}

To generate relative potency factors (RPFs) for the determination of a toxic equivalency factor (TEF), data obtained from this study were compared with data from the 3-month time point of the 2-year bioassay on 2,3,7,8-tetrachlorodibenzo- $p$-dioxin (TCDD), which was conducted as part of the TEF studies at NTP. ${ }^{108}$ RPFs of TCDD congeners are typically estimated by comparing the median effective dose (ED50), no-observed-effect level (NOEL), or lowestobserved-effect level (LOEL) for a response. Use of ED50 is preferred, as it reduces uncertainty related to the NOEL or LOEL. ${ }^{112}$ Ideally, determination of the ED50 requires that the maximal response be similar for both TCDD and the congener, which should also have parallel doseresponse curves. ${ }^{112}$ If the maximal response data are not available, alternative methods can be used to determine if dose-response curves are parallel. ${ }^{131}$ Endpoints selected for RPF determination were thyroid hormone levels, hepatic cell proliferation, and hepatic and pulmonary CYP enzyme activity. These endpoints were selected because they are well-characterized, aryl hydrocarbon (Ah) receptor-mediated effects seen with TCDD exposure and because these endpoints were also assessed at the 3-month interim time point in the 2-year TCDD bioassay. Dose-response curves for HCB and TCDD for select endpoints are shown in Figure 7 and Figure 8; parameters describing model goodness of fit for both data sets are shown in Table 10.

At 3 months, free and total $\mathrm{T}_{4}$ were significantly decreased, and $\mathrm{T}_{3}$ and $\mathrm{TSH}$ were significantly increased in the two highest TCDD doses compared to vehicle control animals in the TCDD study (Figure 7A-D). ${ }^{108}$ For all thyroid hormones measured, determining an HCB RPF was not possible for a variety of reasons. For free and total $\mathrm{T}_{4}, \mathrm{HCB}$ induced more than a $90 \%$ decrease in the hormones, whereas TCDD appeared to produce a maximal $40 \%$ decrease. Higher doses of TCDD may produce further decreases in T4. Because the maximum decreases for HCB and TCDD were not similar for these hormones given the available data, deriving an RPF at this point is not appropriate (Figure 7A, B). For total $\mathrm{T}_{3}$, the dose-response curve diverged at the highest doses of HCB and TCDD (Figure 7C). In other words, at the highest dose of HCB, T3 was decreasing, whereas at the highest doses of TCDD, an increasing trend was observed. There was no effect on TSH in animals administered HCB with this dose range (Figure 7D). Thus, these data indicate that HCB alters thyroid hormones likely through a different mechanism than TCDD. Because the dose-response curves differ, deriving an RPF for changes in thyroid hormones is inappropriate. 

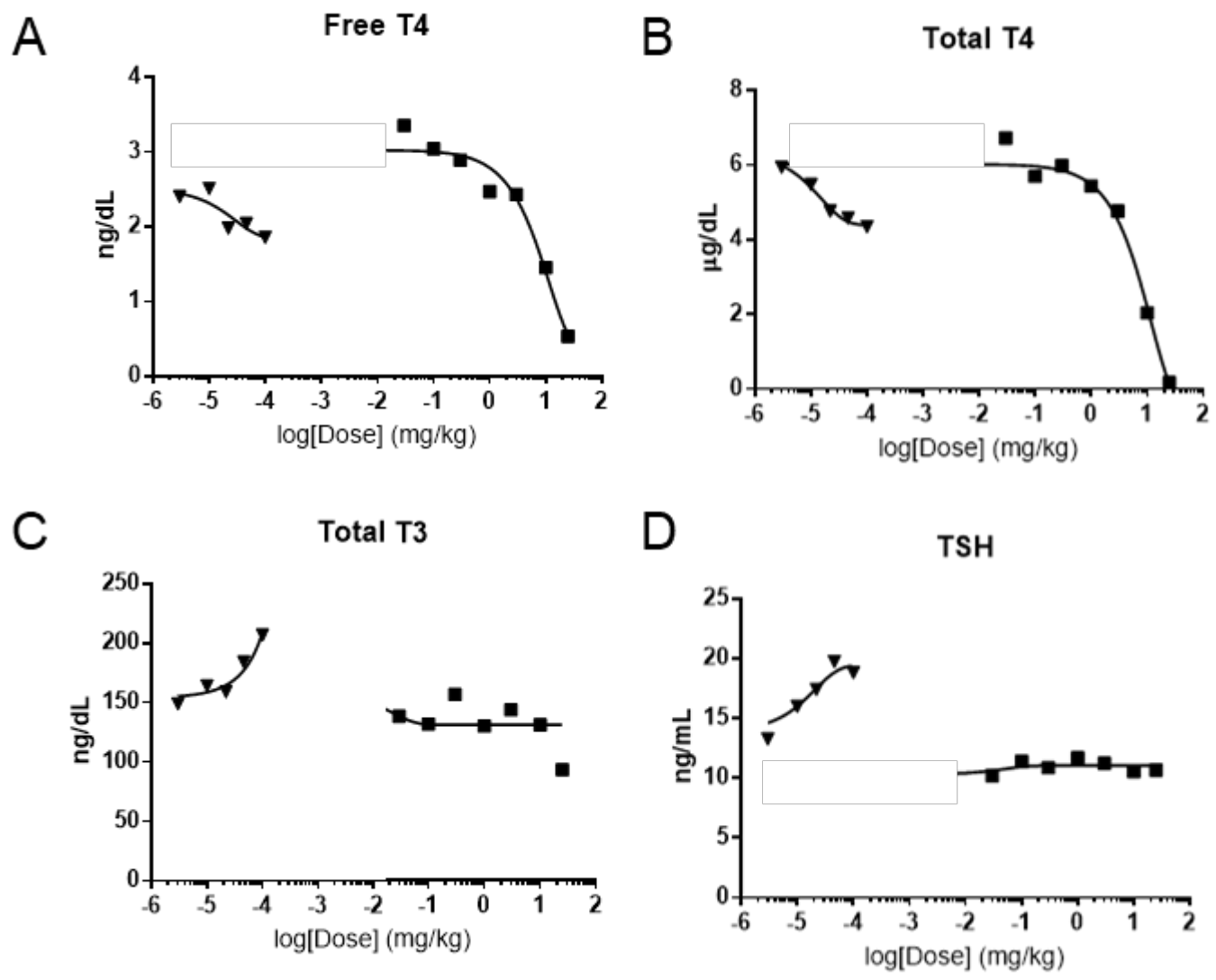

Figure 7. Dose-response Curves for Plasma Free and Total Thyroxine, Triiodothyronine, and Thyroid Stimulating Hormone Levels in Female Rats Administered Hexachlorobenzene or 2,3,7,8-Tetrachlorodibenzo-p-dioxin by Gavage for Three Months

$\mathrm{T}_{3}=$ triiodothyronine; $\mathrm{T}_{4}=$ thyroxine TSH $=$ thyroid stimulating hormone; $\mathrm{HCB}=$ hexachlorobenzene; $\mathrm{TCDD}=2,3,7,8$-tetrachlorodibenzo- $p$-dioxin.

Minimal changes in hepatic cell proliferation occurred after TCDD administration at 3 months at the doses tested. ${ }^{108}$ Due to the minimal response in proliferation, modeling for both TCDD and $\mathrm{HCB}$ was poor and inhibited the determination of an RPF.

In the 2-year TCDD bioassay, all doses increased hepatic A4H, EROD, and PROD and pulmonary EROD activity at 3 months. ${ }^{108}$ Modeling of HCB and TCDD enzyme activity data from both hepatic and pulmonary preparations showed stark differences in the maximum plateau levels (Figure 8). TCDD had higher plateaus in enzyme activity than did HCB with the exception of hepatic PROD activity. Comparing ED 50 for these dose-response curves with different maximal responses is not applicable for RPF determination. 
A

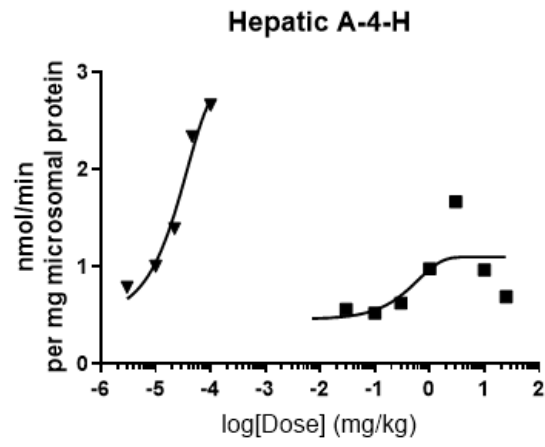

C

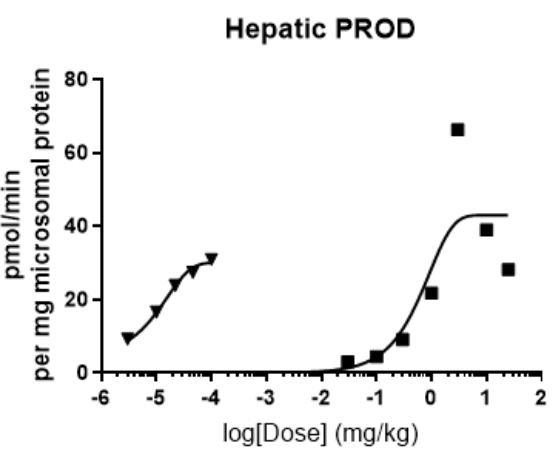

B

Hepatic EROD

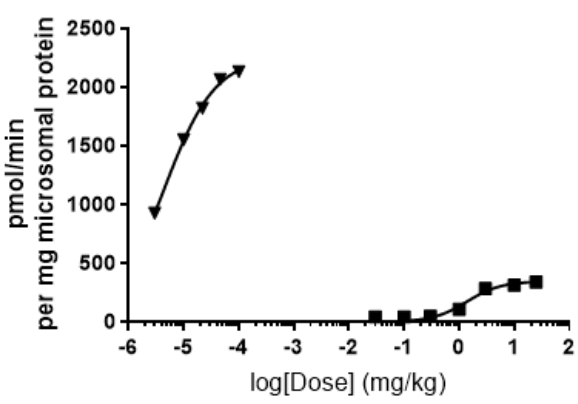

$\rightarrow \mathrm{TCDD}$

Pulmonary EROD

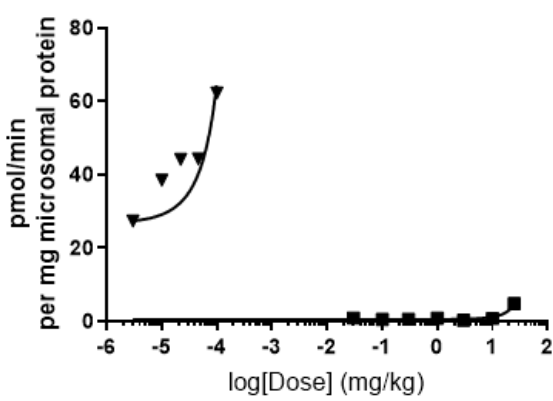

Figure 8. Dose-response Curves for Cytochrome P450 Enzyme Activity in the Liver (A-C) and Lung (D) of Female Rats Administered Hexachlorobenzene or 2,3,7,8-Tetrachlorodibenzo-p-dioxin by Gavage for Three Months

A-4-H = acetanilide-4-hydroxylase; EROD = 7-ethoxyresorufin- $O$-deethylase; PROD = pentoxyresorufin- $O$-deethylase; $\mathrm{HCB}=$ hexachlorobenzene; TCDD = 2,3,7,8-tetrachlorodibenzo- $p$-dioxin. 
Table 10. Nonlinear Curve Goodness-of-Fit Values of Select Endpoints Evaluated in Female Rats Administered Hexachlorobenzene or 2,3,7,8-Tetrachlorodibenzo-p-dioxin by Gavage for Three Months

\begin{tabular}{llcc}
\hline \multicolumn{1}{c}{ Endpoint } & \multicolumn{1}{c}{ Model } & $\mathbf{R}^{2}$ for HCB Data & $\mathbf{R}^{2}$ for TCDD Data \\
\hline Free Thyroxine & One-phase association & 0.68 & 0.18 \\
Total Thyroxine & One-phase association & 0.79 & 0.35 \\
Total Triiodothyronine & One-phase association & $0.21^{\mathrm{a}}$ & 0.94 \\
Thyroid Stimulating Hormone & One-phase association & 0.007 & 0.86 \\
Hepatic Proliferation & One-phase association & 0.27 & 0.08 \\
Hepatic A4H & One-phase association & 0.32 & 0.90 \\
Hepatic EROD & Specific binding with Hill slope & 0.61 & 0.86 \\
Hepatic PROD & One-phase association & 0.64 & 0.93 \\
Pulmonary EROD & Exponential growth equation & 0.63 & 0.47 \\
\hline
\end{tabular}

$\mathrm{HCB}=$ hexachlorobenzene; TCDD = 2,3,7,8-tetrachlorodibenzo-p-dioxin; A4H = acetanilide-4-hydroxylase;

EROD $=7$-ethoxyresorufin- $O$-deethylase; $\mathrm{PROD}=$ pentoxyresorufin- $O$-deethylase.

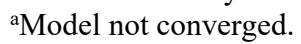

\section{Genetic Toxicology}

HCB (100 to 10,000 $\mu \mathrm{g}$ /plate) was not mutagenic in Salmonella typhimurium strains TA98, TA100, TA1535, or TA1537, with or without rat or hamster liver S9 activation enzymes (Appendix E). ${ }^{93}$

\section{Elimination Study}

After dosing for 13 weeks (day 90), animals in the elimination study were held without dosing until necropsy at 21 (day 146) or 29 (day 201) weeks. At week 21, animals administered HCB had slightly higher body weights compared to vehicle control animals ( $9 \%$ and $12 \%$ higher in the 0.03 and $25 \mathrm{mg} / \mathrm{kg} /$ day groups, respectively), although not statistically significant (Table 11; Appendix F). Mean body weights were similar across all dosed groups at week 29 (Table 11; Appendix F). Absolute and relative liver weights were significantly increased in the high-dose ( $25 \mathrm{mg} / \mathrm{kg} /$ day) group at both 21 and 29 weeks (Table 11; Appendix F). No significant differences in absolute or relative weights of the lung, thymus, and thyroid gland were observed. Rats in the $25 \mathrm{mg} / \mathrm{kg} /$ day group had significantly decreased hepatic A4H activity at week 21 and significantly increased hepatic EROD activity at week 29 (Table 6; Appendix F) compared to vehicle control animals. Hepatic PROD was not evaluated in elimination study samples, and pulmonary EROD activities are not discussed due to values being below the limit of detection (Table 7; Appendix F).

Concentrations of HCB were determined in blood every 2 weeks for 16 weeks after cessation of exposure (Table 12; Appendix F). The half-life of HCB in blood was calculated using a first-decay elimination model and was estimated to be $53(0.03 \mathrm{mg} / \mathrm{kg} / \mathrm{day})$ and $48(25 \mathrm{mg} / \mathrm{kg} /$ day) days. Tissue concentrations were evaluated at weeks 21 and 29 (Table 13; Appendix F). Concentrations in the liver and lung were about equivalent (generally less than twofold difference) to that in blood at both time points. At week 29, however, concentrations of $\mathrm{HCB}$ in the adipose tissue were 37 - to 58-fold higher than blood HCB concentrations, 
demonstrating retention of $\mathrm{HCB}$ in this tissue. As in the core study, the difference between tissue and blood HCB concentrations was smaller in the $25 \mathrm{mg} / \mathrm{kg}$ /day dosed group compared to the $0.03 \mathrm{mg} / \mathrm{kg} /$ day dosed group at both time points. The concentration of HCB in tissues decreased over 8 weeks (comparing concentrations at weeks 21 and 29) by $35 \%, 58 \%$, and $9 \%$ in the adipose tissue, liver, and lung, respectively, in animals from the $0.03 \mathrm{mg} / \mathrm{kg} /$ day group (Table 13;_Appendix F). In the $25 \mathrm{mg} / \mathrm{kg}$ /day group, tissue concentrations decreased by 44\%, $44 \%$, and $13 \%$ in the adipose tissue, liver, and lung, respectively (Table 13; Appendix F).

Table 11. Summary of Select Organ Weights and Organ-Weight-to-Body-Weight Ratios for Elimination Study Female Rats in the Three-month Gavage Study of Hexachlorobenzene ${ }^{a, b}$

\begin{tabular}{|c|c|c|c|}
\hline & $0 \mathrm{mg} / \mathrm{kg} / \mathrm{day}$ & $0.03 \mathrm{mg} / \mathrm{kg} / \mathrm{day}$ & $25 \mathrm{mg} / \mathrm{kg} / \mathrm{day}$ \\
\hline $\mathbf{n}$ & 5 & 5 & 5 \\
\hline \multicolumn{4}{|l|}{ Day 146} \\
\hline Necropsy Body Wt. (g) & $267.5 \pm 10.2$ & $292.9 \pm 14.2$ & $301.5 \pm 10.7$ \\
\hline \multicolumn{4}{|l|}{ Liver } \\
\hline Absolute (g) & $7.78 \pm 0.24 * *$ & $9.16 \pm 0.83$ & $10.87 \pm 0.63^{* *}$ \\
\hline Relative (mg/g) & $29.19 \pm 1.09 * *$ & $31.10 \pm 1.37$ & $35.98 \pm 0.98 * *$ \\
\hline \multicolumn{4}{|l|}{ Day 201} \\
\hline Necropsy Body Wt. (g) & $300.5 \pm 7.2$ & $289.5 \pm 10.8$ & $305.0 \pm 12.2$ \\
\hline \multicolumn{4}{|l|}{ Liver } \\
\hline Absolute (g) & $8.72 \pm 0.44$ & $8.91 \pm 0.19$ & $10.34 \pm 0.55^{*}$ \\
\hline Relative (mg/g) & $29.05 \pm 1.42 *$ & $30.95 \pm 1.34$ & $33.86 \pm 0.77^{*}$ \\
\hline
\end{tabular}

Statistical significance for a dosed group indicates a significant pairwise test compared to the vehicle control group. Statistical significance for the vehicle control group indicates a significant trend test.

$*$ Statistically significant at $\mathrm{p} \leq 0.05 ; * \mathrm{p} \leq 0.01$.

aData are presented as mean \pm standard error.

bStatistical analysis performed by the Jonckheere (trend) and Williams or Dunnett (pairwise) tests. 
Hexachlorobenzene, NTP TOX 77

Table 12. Summary of Concentrations of Hexachlorobenzene in Blood for Elimination Study Female Rats in the Three-month Gavage Study of Hexachlorobenzene ${ }^{a, b}$

\begin{tabular}{|c|c|c|c|c|}
\hline & \multirow{2}{*}{ Day } & \multicolumn{3}{|c|}{ Blood (ng/mL) } \\
\hline & & $0 \mathrm{mg} / \mathrm{kg} / \mathrm{day}$ & $0.03 \mathrm{mg} / \mathrm{kg} /$ day & $25 \mathrm{mg} / \mathrm{kg} /$ day \\
\hline $\mathbf{n}^{\mathrm{c}}$ & & 10 & 10 & 10 \\
\hline & 90 & $63.6 \pm 5.87 * * \mathrm{~d}$ & $187 \pm 9.66^{* * \mathrm{~d}}$ & $131,000 \pm 4,650 * * \mathrm{~d}$ \\
\hline n & & 5 & 5 & 5 \\
\hline & 104 & $49.5 \pm 1.39 * *$ & $176 \pm 3.93 * *$ & $126,000 \pm 3,990 * *$ \\
\hline & 118 & $64.7 \pm 4.17^{* *}$ & $140 \pm 6.76^{* *}$ & $94,800 \pm 1,310^{* *}$ \\
\hline & 132 & $50.2 \pm 3.47^{* *}$ & $110 \pm 2.71 * *$ & $78,200 \pm 3,850^{* *}$ \\
\hline & 146 & $43.9 \pm 2.53 * *$ & $87.2 \pm 6.09 * *$ & $62,400 \pm 2,180^{* *}$ \\
\hline & 160 & $54.0 \pm 1.32 * *$ & $85.7 \pm 3.96^{* *}$ & $53,700 \pm 2,310^{* *}$ \\
\hline & 174 & $41.5 \pm 0.893 * *$ & $76.6 \pm 3.08^{* *}$ & $50,900 \pm 1,350^{* *}$ \\
\hline & 201 & $33.4 \pm 3.25 * *$ & $59.8 \pm 1.87 * *$ & $45,700 \pm 778^{* *}$ \\
\hline
\end{tabular}

Statistical significance for a dosed group indicates a significant pairwise test compared to the vehicle control group. Statistical significance for the vehicle control group indicates a significant trend test.

$* *$ Statistically significant at $\mathrm{p} \leq 0.01$.

a Data are presented as mean \pm standard error.

${ }^{\mathrm{b} S t a t i s t i c a l ~ a n a l y s i s ~ p e r f o r m e d ~ b y ~ t h e ~ J o n c k h e e r e ~(t r e n d) ~ a n d ~ S h i r l e y ~ o r ~ D u n n ~(p a i r w i s e) ~ t e s t s . ~}$

${ }^{\mathrm{c}}$ Number of samples per group. Blood was obtained from 10 animals per group on day 90 . Five animals per group were sampled on days 104, 132, and 146; the other five animals per group were sampled on days 118, 160, 174, and 201 via the retroorbital plexus.

${ }^{\mathrm{d} A v e r a g e ~ o f ~ v a l u e s ~ f r o m ~ b o t h ~ c o h o r t s . ~}$ 
Table 13. Summary of Concentrations of Hexachlorobenzene in Tissues for Elimination Study Female Rats in the Three-month Gavage Study of Hexachlorobenzene $e^{a, b}$

\begin{tabular}{|c|c|c|c|c|c|c|c|c|c|}
\hline \multirow{2}{*}{ Day } & \multicolumn{3}{|c|}{ Liver (ng/g) } & \multicolumn{3}{|c|}{ Lung (ng/g) } & \multicolumn{3}{|c|}{ Adipose $(\mu \mathrm{g} / \mathrm{g})$} \\
\hline & $0 \mathrm{mg} / \mathrm{kg} / \mathrm{day}$ & $0.03 \mathrm{mg} / \mathrm{kg} / \mathrm{day}$ & $25 \mathrm{mg} / \mathrm{kg} / \mathrm{day}$ & 0 mg/kg/day & $0.03 \mathrm{mg} / \mathrm{kg} / \mathrm{day}$ & $25 \mathrm{mg} / \mathrm{kg} / \mathrm{day}$ & $0 \mathrm{mg} / \mathrm{kg} / \mathrm{day}$ & $0.03 \mathrm{mg} / \mathrm{kg} / \mathrm{day}$ & $25 \mathrm{mg} / \mathrm{kg} / \mathrm{day}$ \\
\hline n & 5 & 5 & 5 & 5 & 5 & 5 & 5 & 5 & 5 \\
\hline 146 & $118 \pm 4.11^{* *}$ & $193 \pm 17.0^{* *}$ & $109,000 \pm 8,450 * *$ & $63.9 \pm 9.91 * *$ & $90.0 \pm 8.71$ & $37,500 \pm 4,630 * *$ & $2.72 \pm 0.277 * *$ & $5.27 \pm 0.126^{* *}$ & $3,040 \pm 91.1^{* *}$ \\
\hline 201 & $55.7 \pm 1.62 * *$ & $81.0 \pm 4.89 * *$ & $60,900 \pm 3,170 * *$ & $50.6 \pm 5.58 * *$ & $82.3 \pm 13.0 *$ & $32,700 \pm 2,730 * *$ & $1.82 \pm 0.103 * *$ & $3.45 \pm 0.295^{* *}$ & $1,690 \pm 66.7^{* *}$ \\
\hline
\end{tabular}

Statistical significance for a dosed group indicates a significant pairwise test compared to the vehicle control group. Statistical significance for the vehicle control group indicates a significant trend test.

$*$ Statistically significant at $\mathrm{p} \leq 0.05 ; * * \mathrm{p} \leq 0.01$.

a Data are presented as mean \pm standard error.

bStatistical analysis performed by the Jonckheere (trend) and Shirley or Dunn (pairwise) tests. 


\section{Discussion}

Despite the cessation of its use and production in many parts of the world, hexachlorobenzene (HCB) remains highly persistent in the environment, and chronic, low-dose exposure to HCB in humans continues. Its structural resemblance to 2,3,7,8-tetrachlorodibenzo- $p$-dioxin (TCDD), ability to activate the aryl hydrocarbon (Ah) receptor, TCDD-like toxicities, and bioaccumulative nature suggest HCB be included in the toxic equivalency factor (TEF) methodology (outlined in Van den Berg et al. ${ }^{112}$ ). Consequently, the National Toxicology Program (NTP) conducted this study to determine relative potency values for $\mathrm{HCB}$, measuring a variety of toxicological and biochemical endpoints that also were measured at the 3-month time point in a TCDD 2-year bioassay. ${ }^{108}$ Additional animals were allocated to assess the half-life of HCB in blood and to examine HCB elimination in tissues after repeated exposures to address a knowledge gap in pharmacokinetics in this strain of rat.

\section{Core Study}

HCB had no significant effect on survival. Mean body weight was not significantly changed in most dosed groups, which is consistent with many other subchronic studies of HCB at similar doses. ${ }^{3}$ Some studies have shown decreased body weight with HCB exposure; however, these decreases were generally $<20 \%$ from control body weight. ${ }^{132 ; 133}$ Rats in the highest dose group, $25 \mathrm{mg} \mathrm{HCB} / \mathrm{kg}$ body weight/day ( $\mathrm{mg} / \mathrm{kg} /$ day), had significantly increased mean body weight compared to the vehicle control group at study termination. Slight increases in body weight also have also been observed in another subchronic study of HCB in Wistar rats, although those increases occurred at higher doses $(900 \mathrm{mg} / \mathrm{kg} / \mathrm{day}) .{ }^{57}$

At higher doses of HCB, weights of the spleen $(3,10$, and $25 \mathrm{mg} / \mathrm{kg} /$ day), liver (10 and $25 \mathrm{mg} / \mathrm{kg} /$ day), lung ( $25 \mathrm{mg} / \mathrm{kg} /$ day $)$, and kidney ( $25 \mathrm{mg} / \mathrm{kg} /$ day) were significantly increased compared to those of the vehicle control group. Increases in liver and spleen weights were correlated with significant pathological changes, such as increased incidences of hepatocyte hypertrophy and lymphoid hyperplasia of the spleen in the 10 and $25 \mathrm{mg} / \mathrm{kg} /$ day groups. Enlargement of the liver and spleen has been observed in previous studies of HCB. ${ }^{57 ; 132 ; 134}$ The significant increase in kidney weight in the $25 \mathrm{mg} / \mathrm{kg} /$ day group was not associated with any significant morphological changes.

Increased incidences of chronic inflammation occurred in the lung and skin. Inflammation in the lung and skin has also been observed in a 4-week dietary HCB exposure study. ${ }^{57}$ Female rats from multiple strains developed epidermal hyperplasia, activated venule endothelium, and inflammatory infiltrates in the skin and high endothelial-like venules, perivascular infiltrate, and accumulation of macrophages in the lung. Serum immunoglobulins as indicators of immunomodulation correlated with skin but not lung lesions. These data suggest that HCB induces a chronic inflammatory reaction and that HCB-induced skin and lung lesions have different etiologies ${ }^{57}$ Furthermore, inflammatory effects of HCB appear thymus-independent. ${ }^{58}$ Thus, the observed thymic atrophy at $25 \mathrm{mg} / \mathrm{kg} / \mathrm{day}$, which did not correspond with decreased thymic weight, might not be related to the skin or lung inflammatory lesions. TCDD has been reported to be immunomodulatory, particularly in barrier tissues like the skin and lung, ${ }^{135}$ though in a 2-year study in rats, TCDD exposure was not associated with increased incidences of skin or lung inflammation. ${ }^{108}$ 
The incidence of mammary gland hyperplasia was increased in the $25 \mathrm{mg} / \mathrm{kg} /$ day group compared to the vehicle control group. Mammary gland hyperplasia has been observed in other rat studies evaluating HCB exposure. Sprague Dawley rats given $100 \mathrm{mg} / \mathrm{kg} \mathrm{HCB}$ by gavage for 45 days and initiated with $\mathrm{N}$-nitroso-N-methylurea had higher incidence of preneoplastic lesions in the mammary gland. ${ }^{104}$ Increased mammary gland hyperplasia also was observed in C57BL6/N mice treated with $3 \mathrm{mg} / \mathrm{kg} \mathrm{HCB}$ via intraperitoneal injection for 21 days. ${ }^{136}$ These mammary gland effects of HCB have been proposed as being due to activation of the Ah receptor, which influences insulin growth factor, transforming growth factor beta 1, and estrogen receptor signaling pathways. ${ }^{137}$

Maxillary incisor degeneration was observed in animals administered HCB at doses of $\geq 1 \mathrm{mg} / \mathrm{kg} /$ day. The morphology and distribution of HCB-induced incisor lesions in rats are consistent with injury to a selective population of preodontoblasts and support a direct cytotoxic mechanism of action. ${ }^{130}$ Dioxins can interfere with the development of incisors and molars and can alter mesenchymal and epithelial dental tissues. ${ }^{138}$ The mechanism by which dioxins cause dental injury is thought to be mediated through the Ah receptor together with the Ah receptor nuclear translocator protein. ${ }^{139}$ Others have suggested a role for vitamin $\mathrm{A}$ in mediating the toxic effects of TCDD because TCDD is known to interfere with vitamin A metabolism. ${ }^{140 ;}$; 141 The dentin effects of TCDD are similar to those observed with vitamin A deficiency. ${ }^{142}$ Decreased regional blood flow also has been suggested as a possible mechanism by which dioxins injure dental tissues. ${ }^{138}$ Dentin niches, which were observed in this study, however, are not reported features of TCDD toxicity. $138 ; 139 ; 142-147$

At study termination, serum total triiodothyronine ( $\mathrm{T}_{3}$ ) was decreased in the $25 \mathrm{mg} / \mathrm{kg} /$ day group, and both free and total thyroxine ( $\left.\mathrm{T}_{4}\right)$ were decreased in the 10 and $25 \mathrm{mg} / \mathrm{kg} /$ day groups. These observed changes in thyroid hormones were not accompanied by a compensatory increase in thyroid stimulating hormone (TSH) or changes in thyroid gland pathology (e.g., hyperplasia). Other rat studies have shown similar decreases in total $\mathrm{T}_{4}$, with or without decreases in total $\mathrm{T}_{3}$ or increases in TSH. ${ }^{64 ; 66 ; 148-151}$ Evaluation of another time point would provide further insight into mechanisms of HCB-associated thyroid impairment. Studies suggest that decreases in circulating total $\mathrm{T}_{4}$ could be due to increased glucuronidation (i.e., increased uridine diphosphoglucuronosyl transferase) leading to increased biliary excretion of $\mathrm{T}_{4}{ }^{51 ; 151}$ Alterations in thyroid hormone homeostasis are well-described with TCDD exposure and are purported to undergo a similar extrathyroidal mechanism similar to that of $\mathrm{HCB} .{ }^{152}$ In rats administered $1,000 \mathrm{mg} / \mathrm{kg} \mathrm{HCB}$ via stomach tube, increases in total body 5 '-deiodinase type I (which converts $\mathrm{T}_{4}$ to $\mathrm{T}_{3}$ ) was considered a major contributor to the maintenance of serum $\mathrm{T}_{3}$ levels. ${ }^{151}$ Moreover, metabolites of $\mathrm{HCB}$ might contribute to alterations in total and free $\mathrm{T}_{4}$ concentrations by competitively binding to thyroid transport proteins. ${ }^{148}$

A slight, nonsignificant increase in hepatic cell proliferation occurred with 10 and $25 \mathrm{mg} / \mathrm{kg} / \mathrm{day}$ HCB. Hepatic cell proliferation is often studied to understand the tumor promotion potential of a chemical. Because TCDD and related congeners (like HCB) are not direct genotoxic agents, their primary mode of carcinogenic action is presumed to be via growth dysregulation mediated through the Ah receptor, either by increasing net growth or decreasing cell death (reviewed in Schwarz et al. ${ }^{153}$ ). Though the increase in cell proliferation due to Ah receptor activation typically occurs in the first week of exposure, ${ }^{154}$ the continued presence of higher cell proliferation in HCB-dosed animals may be due to a higher number of proliferating hepatocytes 
from earlier exposures and/or a regenerative response to liver injury. HCB exposure has been observed to produce liver tumors in three species (mice, rats, and hamsters). ${ }^{1}$ This effect is mediated, in part, through the Ah receptor because Ah receptor-dependent cell proliferation pathways have been shown to be activated following HCB exposure. ${ }^{155-157}$ Other mechanisms are likely involved in HCB carcinogenicity, however, as demonstrated by the large induction of hepatic pentoxyresorufin- $O$-deethylase (PROD) activity, which is likely due to constitutive androstane receptor (CAR) activation. CAR is known to participate in rodent

hepatocarcinogenesis. ${ }^{158}$ In fact, in rodents, the CAR-activator phenobarbital increased replicative DNA synthesis in regions of altered hepatic foci produced by initiation with diethylnitrosamine, ${ }^{159}$ indicating the role of CAR in tumor promotion.

Hepatic 7-ethoxyresorufin- $O$-deethylase (EROD), acetanilide-4-hydroxylase (A4H), and PROD activity was significantly increased in most groups of rats administered $\mathrm{HCB}$, suggesting that CYP1A1, CYP1A2, CYP2B1, and CYP2B2 expression was induced by HCB. Increases in pulmonary EROD activity were observed only at $25 \mathrm{mg} / \mathrm{kg} /$ day. These findings are consistent with previous studies showing induction of Cyp genes by HCB. ${ }^{64 ; 102 ; 160}$ Extensive studies show that TCDD induces CYP1A1 expression through the Ah receptor. ${ }^{161}$ PROD activity is often associated with induction of phenobarbital-inducible CYP enzymes such as CYP2B1 and CYP2B2. Though this may suggest broader activity of HCB, PROD activity was also increased with TCDD exposure and thus might not be entirely specific to CYP2B enzymes, reflecting some CYP1A activity. Indeed, CYP1A1 has been found to also dealkylate pentoxyresorufin. ${ }^{162}$ Additionally, in this study, tissues were frozen prior to evaluation of microsomal activity, which may have resulted in a loss of activity ${ }^{115}$ and an incomplete picture of HCB-induced microsomal enzymes.

Concentrations of HCB in blood and tissues increased in proportion to dose. The distribution pattern of HCB among the tissues in this study is similar to that observed in single administration studies in which the concentration of HCB in the blood and liver was higher or equivalent to that in the lung but lower than concentrations in adipose tissue. ${ }^{34 ; 35 ; 163-166}$ Accumulation of HCB in adipose tissue is likely due to the lipophilicity of HCB. The ratios of tissue to blood HCB concentrations after repeated dosing in this study were similar to those observed in the single administration toxicokinetic study (Appendix D). The decreasing difference between tissue and blood HCB concentration with increasing dose suggests saturation of HCB accumulation after repeated exposure to high doses.

\section{Relative Potency Factor Determination}

The generation of relative potency factors (RPFs) of HCB compared with TCDD was deemed inappropriate due to significant differences in the dose-response relationships for $\mathrm{Ah}$ receptor-mediated activity. The maximal response for $\mathrm{HCB}$ was not reached in many of the endpoints, and the available data did not suggest parallel dose-response curves with TCDD. Although exposure to HCB yields some of the same toxicities as TCDD exposure (e.g., hepatic porphyria, altered thyroid hormone, and tumorigenicity), the lack of parallel dose-response curves and the differences in directionality and maximum effect in some endpoints suggest that the mechanisms of action of HCB differ from those of TCDD. For example, whereas HCB has been found to alter 5'-deiodinase activities in the liver and thyroid gland, changes in 5 '-deiodinase likely do not significantly influence circulating levels of $\mathrm{T}_{4}$ or $\mathrm{T}_{3}$ in TCDD- 
exposed rats. ${ }^{167} \mathrm{HCB}$ has been found to induce apoptosis in rat hepatocytes and thyroid follicular cells, ${ }^{149 ;} 168$ unlike TCDD, which tends to suppress apoptosis. ${ }^{153 ; 169}$

\section{Elimination Study}

HCB was retained in the adipose tissue at 8 and 16 weeks after cessation of exposure. Evidenced by approximately equivalent blood and tissue $\mathrm{HCB}$ concentrations, minimal retention was observed in the lung and liver. The toxicological effects of HCB exposure, such as increased liver weight and elevated hepatic EROD activity, were still present at both postexposure time points in the $25 \mathrm{mg} / \mathrm{kg} /$ day dose group, but the effects were of a lower magnitude; there were no significant effects on those endpoints in the $0.03 \mathrm{mg} / \mathrm{kg} /$ day dose group at later time points. Taken together, HCB is retained primarily in the adipose tissue and continues to influence biological processes, even up to 16 weeks after cessation of exposure.

The half-life of HCB after repeated administration was assessed in the blood because these kinetic parameters have not been determined for female Sprague Dawley rats. In the present study, the half-life of HCB in blood of female Sprague Dawley (Hsd:Sprague Dawley ${ }^{\circledR}$ SD $^{\circledR}$ ) rats was estimated to be $53(0.03 \mathrm{mg} / \mathrm{kg} /$ day $)$ and $48(25 \mathrm{mg} / \mathrm{kg} /$ day $)$ days. The half-life of HCB in blood of female Sprague Dawley rats after a single administration of 0.03 and $30 \mathrm{mg} / \mathrm{kg}$ was estimated to be 23 and 11 days, respectively (Appendix D). These data suggest slower HCB elimination following repeated exposures.

Under the conditions of this 3-month gavage study, oral administration of HCB in female Sprague Dawley rats resulted in dose-related lesions in the liver, lung, spleen, mammary gland, skin, thymus, and teeth. $\mathrm{HCB}$ administration decreased total $\mathrm{T}_{3}$, free $\mathrm{T}_{4}$, and total $\mathrm{T}_{4}$; there were no compensatory increases in TSH and no thyroid histological changes observed. Consistent with literature indicating that $\mathrm{HCB}$ acts through other mechanisms in addition to activation of the Ah receptor, these data indicate that HCB should not be included in the TEF methodology. 


\section{References}

1. International Programme on Chemical Safety (IPCS). Environmental Health Criteria 195: Hexachlorobenzene. Geneva, Switzerland: World Health Organization; 1997. http://www.inchem.org/documents/ehc/ehc/ehc195.htm\#SectionNumber:2.2 [Accessed: March $14,2011]$

2. O'Neil MJ. The Merck Index. 14th ed. p. 808. Whitehouse Station, NJ: Merck \& Company. 2006.

3. Agency for Toxic Substances and Disease Registry (ATSDR). Toxicological profile for hexachlorobenzene. Atlanta, GA: U.S. Department of Health and Human Services, Public Health Service, Agency for Toxic Substances and Disease Registry; 2002.

http://www.atsdr.cdc.gov/ToxProfiles/tp90.pdf [Accessed: March 14, 2011]

4. Tiernan TO, Taylor ML, Garrett JH, VanNess GF, Solch JG, Wagel DJ, Ferguson GL, Schecter A. Sources and fate of polychlorinated dibenzodioxins, dibenzofurans and related compounds in human environments. Environ Health Perspect. 1985; 59:145-158. http://dx.doi.org/10.1289/ehp.59-1568078

5. Bailey RE. Global hexachlorobenzene emissions. Chemosphere. 2001; 43(2):167-182. https://doi.org/10.1016/S0045-6535(00)00186-7

6. Rippen G, Frank R. Estimation of hexachlorobenzene pathways from the technosphere into the environment. IARC Sci Publ. 1986; (77):45-52.

7. International Agency for Research on Cancer (IARC). IARC monograph on the evaluation of the carcinogenic risk of chemicals to humans: Some halogenated hydrocarbons, Vol. 20.

Hexachlorobenzene. Lyon, France: IARC; 1979. p. 155-178.

8. Jacoff FS, Scarberry R, Rosa D. Source assessment of hexachlorobenzene from the organic chemical manufacturing industry. IARC Sci Publ. 1986; (77):31-37.

9. Ritter L, Solomon KR, Forget J, Stemeroff M, O'Leary C. A review of selected persistent organic pollutants: DDT-aldrin-dieldrin-endrin-chlordane, heptachlor-hexachlorobenzene-mïrextoxaphene, polychlorinated biphenyls, dioxins and furans Geneva, Switzerland: Prepared for the International Programme on Chemical Safety, Inter-Organization Programme for the Sound Management of Chemicals; 1995. PCS/95.39.

https://www.who.int/ipcs/assessment/en/pcs_95_39_2004_05_13.pdf

10. U. S. Environmental Protection Agency (USEPA). Toxic Release Inventory. Washington, DC; 2012. http://www.epa.gov/tri [Accessed: May 10, 2012]

11. United States Food and Drug Administration (FDA). Total diet study: Market baskets 1991-3 through 2003-4. College Park, MD: United States Food and Drug Administration, Center for Food Safety and Applied Nutrition, Office of Food Safety; 2006.

https://www.fda.gov/media/77962/download

12. Gunderson EL. FDA Total Diet Study, July 1986-April 1991, dietary intakes of pesticides, selected elements, and other chemicals. J AOAC Int. 1995; 78(6):1353-1363. 
13. U. S. Department of Agriculture (USDA). Pesticide Data Program: Annual summary, calendar year 2007. Washington, DC: U.S. Department of Agriculture, Agriculture Marketing Service; 2008.

https://web.archive.org/web/20111024232422/http://www.ams.usda.gov/AMSv1.0/getfile?dDoc Name=STELPRDC5074338 [Accessed: March 10, 2011]

14. Patterson DG, Jr., Wong LY, Turner WE, Caudill SP, Dipietro ES, McClure PC, Cash TP, Osterloh JD, Pirkle JL, Sampson EJ et al. Levels in the U.S. population of those persistent organic pollutants (2003-2004) included in the Stockholm Convention or in other long range transboundary air pollution agreements. Environ Sci Technol. 2009; 43(4):1211-1218. http://dx.doi.org/10.1021/es801966w

15. Centers for Disease Control and Prevention (CDC). Fourth national report on human exposure to environmental chemicals: Updated tables, January 2019. Vol 2. Atlanta, GA: United States Department of Health and Human Services, Centers for Disease Control and Prevention; 2019.

https://www.cdc.gov/exposurereport/pdf/FourthReport_UpdatedTables_Volume2_Jan2019$\underline{508 . p d f}$

16. Weldon RH, Webster M, Harley KG, Bradman A, Fenster L, Davis MD, Hubbard A, Barr DB, Holland N, Eskenazi B. Serum persistent organic pollutants and duration of lactation among Mexican-American women. J Environ Public Health. 2010; 2010:1-11.

http://dx.doi.org/10.1155/2010/861757

17. Dallaire F, Dewailly Ã, Muckle G, Ayotte P. Time trends of persistent organic pollutants and heavy metals in umbilical cord blood of Inuit infants born in Nunavik (Quebec, Canada) between 1994 and 2001. Environ Health Perspect. 2003; 111(13):1660-1664.

http://dx.doi.org/10.1289/ehp.6269

18. Polder A, Thomsen C, Lindstrom G, Loken KB, Skaare JU. Levels and temporal trends of chlorinated pesticides, polychlorinated biphenyls and brominated flame retardants in individual human breast milk samples from Northern and Southern Norway. Chemosphere. 2008; 73(1):1423. http://dx.doi.org/10.1016/j.chemosphere.2008.06.002

19. Hardell E, Carlberg M, Nordstrom M, van Bavel B. Time trends of persistent organic pollutants in Sweden during 1993-2007 and relation to age, gender, body mass index, breastfeeding and parity. Sci Total Environ. 2010; 408(20):4412-4419.

http://dx.doi.org/10.1016/j.scitotenv.2010.06.029

20. Bleavins MR, Breslin WJ, Aulerich RJ, Ringer RK. Excretion and placental and mammary transfer of hexachlorobenzene in the European ferret (Mustela putorius furo). J Toxicol Environ Health A. 1982; 10(6):929-940. http://dx.doi.org/10.1080/15287398209530307

21. Scheufler E, Rozman KK. Comparative decontamination of hexachlorobenzene-exposed rats and rabbits by hexadecane. J Toxicol Environ Health. 1984; 14(2-3):353-362.

http://dx.doi.org/10.1080/15287398409530585

22. Bailey J, Knauf V, Mueller W, Hobson W. Transfer of hexachlorobenzene and polychlorinated biphenyls to nursing infant rhesus monkeys: Enhanced toxicity. Environ Res. 1980; 21(1):190-196. http://dx.doi.org/10.1016/0013-9351(80)90021-3 
23. Goldey ES, Taylor DH. Developmental neurotoxicity following premating maternal exposure to hexachlorobenzene in rats. Neurotoxicol Teratol. 1992; 14(1):15-21.

http://dx.doi.org/10.1016/0892-0362(92)90024-5

24. Nakashima Y, Ohsawa S, Umegaki K, Ikegami S. Hexachlorobenzene accumulated by dams during pregnancy is transferred to suckling rats during early lactation. J Nutr. 1997; 127(4):648654. http://dx.doi.org/10.1093/jn/127.4.648

25. Nakashima Y, Ohsawa S, Ikegami S. High-Fat diet enhances accumulation of hexachlorobenzene in rat dams and delays its transfer from rat dams to suckling pups through milk. J Agric Food Chem. 1999; 47(4):1587-1592. http://dx.doi.org/10.1021/jf980831c

26. Nakashima Y, Ikegami S. High-fat diet enhances the accumulation of hexachlorobenzene (HCB) by pregnant rats during continuous exposure to HCB. J Agric Food Chem. 2003; 51(6):1628-1633. http://dx.doi.org/10.1021/jf020869w

27. Koss G, Koransky W, Steinbach K. Studies on the toxicology of hexachlorobenzene. II. Identification and determination of metabolites. Arch Toxicol. 1976; 35(2):107-114. http://dx.doi.org/10.1007/BF00372764

28. Koss G, Koransky W, Steinbach K. Studies on the toxicology of hexachlorobenzene. IV. Sulphur-containing metabolites. Arch Toxicol. 1979; 42(1):19-31. http://dx.doi.org/10.1007/BF00351821

29. Smith AG, Francis JE. Evidence for the active renal secretion of S-pentachlorophenyl-Nacetyl-L-cysteine by female rats. Biochem Pharmacol. 1983; 32(24):3797-3801. http://dx.doi.org/10.1016/0006-2952(83)90152-1

30. To-Figueras J, Barrot C, Rodamilans M, Gomez-Catalan J, Torra M, Brunet M, Sabater F, Corbella J. Accumulation of hexachlorobenzene in humans: A long standing risk. Hum Exp Toxicol. 1995; 14(1):20-23. http://dx.doi.org/10.1177/096032719501400105

31. Renner G, Nguyen PT. Mechanisms of the reductive denitration of pentachloronitrobenzene (PCNB) and the reductive dechlorination of hexachlorobenzene (HCB). Xenobiotica. 1984; 14(9):705-710. http://dx.doi.org/10.3109/00498258409151468

32. Renner G, Nguyen PT. Biotransformation of derivatives of the fungicides pentachloronitrobenzene and hexachlorobenzene in mammals. Xenobiotica. 1984; 14(9):693704. http://dx.doi.org/10.3109/00498258409151467

33. Rizzardini M, Smith AG. Sex differences in the metabolism of hexachlorobenzene by rats and the development of porphyria in females. Biochem Pharmacol. 1982; 31(22):3543-3548. http://dx.doi.org/10.1016/0006-2952(82)90573-1

34. Mehendale HM, Fields M, Mathews HB. Metabolism and effects of hexachlorobenzene on hepatic microsomal enzymes in the rat. J Agric Food Chem. 1975; 23(2):261-265. http://dx.doi.org/10.1021/jf60198a042

35. Yamaguchi $Y$, Kawano M, Tatsukawa R. Tissue distribution and excretion of hexabromobenzene (HBB) and hexachlorobenzene (HCB) administered to rats. Chemosphere. 1986; 15(4):453-459. http://dx.doi.org/10.1016/0045-6535(86)90539-4 
36. Yesair DW, Feder PI, Chin AE, Naber SJ, Kuiper-Goodman T, Scott CS, Robinson PE. Development, evaluation and use of a pharmacokinetic model for hexachlorobenzene. IARC Sci Publ. 1986; (77):297-318.

37. Freeman RA, Rozman KK, Wilson AG. Physiological pharmacokinetic model of hexachlorobenzene in the rat. Health Phys. 1989; 57:139-147.

http://dx.doi.org/10.1097/00004032-198907001-00017

38. Lu Y, Lohitnavy M, Reddy MB, Lohitnavy O, Ashley A, Yang RS. An updated physiologically based pharmacokinetic model for hexachlorobenzene: Incorporation of pathophysiological states following partial hepatectomy and hexachlorobenzene treatment. Toxicol Sci. 2006; 91(1):29-41. http://dx.doi.org/10.1093/toxsci/kfj133

39. Schlummer M, Moser GA, McLachlan MS. Digestive tract absorption of PCDD/Fs, PCBs, and HCB in humans: Mass balances and mechanistic considerations. Toxicol Appl Pharmacol. 1998; 152(1):128-137. https://doi.org/10.1006/taap.1998.8487

40. Arnot JA, Mackay D, Parkerton TF, Zaleski RT, Warren CS. Multimedia modeling of human exposure to chemical substances: The roles of food web biomagnification and biotransformation. Environ Toxicol Chem. 2010; 29(1):45-55. http://dx.doi.org/10.1002/etc.15

41. Weistrand C, Noren K. Polychlorinated naphthalenes and other organochlorine contaminants in human adipose and liver tissue. J Toxicol Environ Health A. 1998; 53(4):293-311. http://dx.doi.org/10.1080/009841098159295

42. Dewailly E, Mulvad G, Pedersen HS, Ayotte P, Demers A, Weber J-P, Hansen JC.

Concentration of organochlorines in human brain, liver, and adipose tissue autopsy samples from Greenland. Environ Health Perspect. 1999; 107(10):823-828.

http://dx.doi.org/10.1289/ehp.99107823

43. Minh TB, Watanabe M, Tanabe S, Yamada T, Hata J, Watanabe S. Specific accumulation and elimination kinetics of tris(4-chlorophenyl)methane, tris(4-chlorophenyl)methanol, and other persistent organochlorines in humans from Japan. Environ Health Perspect. 2001; 109(9):927935. http://dx.doi.org/10.1289/ehp.01109927

44. Lackmann GM, Goen T, Tolliner U, Schaller KH, Angerer J. PCBs and HCB in serum of full-term German neonates. Lancet. 1996; 348(9033):1035. http://dx.doi.org/10.1016/S0140$\underline{6736(05) 64967-7}$

45. Ando M, Hirano S, Itoh Y. Transfer of hexachlorobenzene (HCB) from mother to new-born baby through placenta and milk. Arch Toxicol. 1985; 56(3):195-200.

http://dx.doi.org/10.1007/BF00333426

46. Sala M, Sunyer J, Otero R, Santiago-Silva M, Ozalla D, Herrero C, To-Figueras J, Kogevinas $\mathrm{M}$, Anto JM, Camps $\mathrm{C}$ et al. Health effects of chronic high exposure to hexachlorobenzene in a general population sample. Arch Environ Health. 1999; 54(2):102-109. http://dx.doi.org/10.1080/00039899909602243 
47. Song S, Ma J, Tian Q, Tong L, Guo X. Hexachlorobenzene in human milk collected from Beijing, China. Chemosphere. 2013; 91(2):145-149.

http://dx.doi.org/10.1016/j.chemosphere.2012.12.019

48. To-Figueras J, Sala M, Otero R, Barrot C, Santiago-Silva M, Rodamilans M, Herrero C, Grimalt J, Sunyer J. Metabolism of hexachlorobenzene in humans: Association between serum levels and urinary metabolites in a highly exposed population. Environ Health Perspect. 1997; 105(1):78-83. http://dx.doi.org/10.1289/ehp.9710578

49. Koss G, Reuter A, Koransky W. Excretion of metabolites of hexachlorobenzene in the rat and in man. IARC Sci Publ. 1986; (77):261-266.

50. To-Figueras J, Barrot C, Sala M, Otero R, Silva M, Ozalla MD, Herrero C, Corbella J, Grimalt J, Sunyer J. Excretion of hexachlorobenzene and metabolites in feces in a highly exposed human population. Environ Health Perspect. 2000; 108(7):595-598.

http://dx.doi.org/10.1289/ehp.00108595

51. van Raaij JA, Kaptein E, Visser TJ, van den Berg KJ. Increased glucuronidation of thyroid hormone in hexachlorobenzene-treated rats. Biochem Pharmacol. 1993; 45(3):627-631. http://dx.doi.org/10.1016/0006-2952(93)90136-K

52. Hahn ME, Goldstein JA, Linko P, Gasiewicz TA. Interaction of hexachlorobenzene with the receptor for 2,3,7,8-tetrachlorodibenzo-p-dioxin in vitro and in vivo. Evidence that hexachlorobenzene is a weak Ah receptor agonist. Arch Biochem Biophys. 1989; 270(1):344355. http://dx.doi.org/10.1016/0003-9861(89)90037-4

53. Sinclair PR, Gorman N, Walton HS, Bement WJ, Dalton TP, Sinclair JF, Smith AG, Nebert DW. CYP1A2 is essential in murine uroporphyria caused by hexachlorobenzene and iron. Toxicol Appl Pharmacol. 2000; 162(1):60-67. http://dx.doi.org/10.1006/taap.1999.8832

54. Kimbrough RD, Linder RE. The toxicity of technical hexachlorobenzene in the Sherman strain rat. A preliminary study. Res Commun Chem Pathol Pharmacol. 1974; 8(4):653-664.

55. Goldstein JA, Friesen M, Scotti TM, Hickman P, Hass JR, Bergman H. Assessment of the contribution of chlorinated dibenzo-p-dioxins and dibenzofurans to hexachlorobenzene-induced toxicity, porphyria, changes in mixed function oxygenases, and histopathological changes. Toxicol Appl Pharmacol. 1978; 46(3):633-649. http://dx.doi.org/10.1016/0041-008X(78)90309$\underline{5}$

56. Kitchin KT, Linder RE, Scotti TM, Walsh D, Curley AO, Svendsgaard D. Offspring mortality and maternal lung pathology in female rats fed hexachlorobenzene. Toxicology. 1982; 23(1):33-39. http://dx.doi.org/10.1016/0300-483X(82)90039-7

57. Michielsen CP, Bloksma N, Ultee A, van Mil F, Vos JG. Hexachlorobenzene-induced immunomodulation and skin and lung lesions: A comparison between brown Norway, Lewis, and Wistar rats. Toxicol Appl Pharmacol. 1997; 144(1):12-26.

http://dx.doi.org/10.1006/taap.1997.8104

58. Michielsen CC, van Loveren H, Vos JG. The role of the immune system in hexachlorobenzene-induced toxicity. Environ Health Perspect. 1999; 107(Suppl 5):783-792. 
59. Michielsen CP, Leusink-Muis A, Vos JG, Bloksma N. Hexachlorobenzene-induced eosinophilic and granulomatous lung inflammation is associated with in vivo airways hyperresponsiveness in the Brown Norway rat. Toxicol Appl Pharmacol. 2001; 172(1):11-20. http://dx.doi.org/10.1006/taap.2001.9126

60. Muller WF, Hobson W, Fuller GB, Knauf W, Coulston F, Korte F. Endocrine effects of chlorinated hydrocarbons in rhesus monkeys. Ecotoxicol Environ Saf. 1978; 2(2):161-172. http://dx.doi.org/10.1016/0147-6513(78)90007-6

61. Foster WG, McMahon A, Villeneuve DC, Jarrell JF. Hexachlorobenzene (HCB) suppresses circulating progesterone concentrations during the luteal phase in the cynomolgus monkey. $\mathrm{J}$ Appl Toxicol. 1992; 12(1):13-17. http://dx.doi.org/10.1002/jat.2550120105

62. Foster WG, McMahon A, Younglai EV, Jarrell JF, Lecavalier P. Alterations in circulating ovarian steroids in hexachlorobenzene-exposed monkeys. Reprod Toxicol. 1995; 9(6):541-548. http://dx.doi.org/10.1016/0890-6238(95)02004-7

63. Foster WG, Pentick JA, McMahon A, Lecavalier PR. Body distribution and endocrine toxicity of hexachlorobenzene (HCB) in the female rat. J Appl Toxicol. 1993; 13(2):79-83. http://dx.doi.org/10.1002/jat.2550130203

64. Rozman K, Gorski JR, Rozman P, Parkinson A. Reduced serum thyroid hormone levels in hexachlorobenzene-induced porphyria. Toxicol Lett. 1986; 30(1):71-78.

http://dx.doi.org/10.1016/0378-4274(86)90181-5

65. Visser T, Kaptein E, van Toor H, Van Raaij J, Van den Berg K, Joe C, Van Engelen J, Brouwer A. Glucuronidation of thyroid hormone in rat liver: Effects of in vivo treatment with microsomal enzyme inducers and in vitro assay conditions. Endocrinology. 1993; 133(5):21772186.

66. Kleiman de Pisarev DL, Ferramola de Sancovich AM, Sancovich HA. Hepatic indices of thyroid status in rats treated with hexachlorobenzene. J Endocrinol Invest. 1995; 18(4):271-276. http://dx.doi.org/10.1007/BF03347812

67. Smith AG, Dinsdale D, Cabral JR, Wright AL. Goitre and wasting induced in hamsters by hexachlorobenzene. Arch Toxicol. 1987; 60(5):343-349. http://dx.doi.org/10.1007/BF00295753

68. Vos JG, van Logten MJ, Kreeftenberg JG, Kruizinga W. Hexachlorobenzene-induced stimulation of the humoral immune response in rats. Ann N Y Acad Sci. 1979; 320:535-550.

69. Can C, Nigogosyan G. Acquired toxic porphyria cutanea tarda due to hexachlorobenzene. Report of 348 cases caused by this fungicide. JAMA. 1963; 183:88-91.

70. Herrero C, Ozalla D, Sala M, Otero R, Santiago-Silva M, Lecha M, To-Figueras J, Deulofeu $\mathrm{R}$, Mascaro JM, Grimalt J et al. Urinary porphyrin excretion in a human population highly exposed to hexachlorobenzene. Arch Dermatol. 1999; 135(4):400-404. http://dx.doi.org/10.1001/archderm.135.4.400

71. Sala M, Sunyer J, Herrero C, To-Figueras J, Grimalt J. Association between serum concentrations of hexachlorobenzene and polychlorobiphenyls with thyroid hormone and liver 
enzymes in a sample of the general population. Occup Environ Med. 2001; 58(3):172-177. http://dx.doi.org/10.1136/oem.58.3.172

72. Arnold DL, Moodie CA, Charbonneau SM, Grice HC, McGuire PF, Bryce FR, Collins BT, Zawidzka ZZ, Krewski DR, Nera EA. Long-term toxicity of hexachlorobenzene in the rat and the effect of dietary vitamin A. Food Chem Toxicol. 1985; 23(9):779-793.

http://dx.doi.org/10.1016/0278-6915(85)90278-9

73. Grant DL, Phillips WE, Hatina GV. Effect of hexachlorobenzene on reproduction in the rat. Arch Environ Contam Toxicol. 1977; 5(1):207-216. http://dx.doi.org/10.1007/BF02220904

74. Courtney KD, Copeland MF, Robbins A. The effects of pentachloronitrobenzene, hexachlorobenzene, and related compounds on fetal development. Toxicol Appl Pharmacol. 1976; 35(2):239-256. http://dx.doi.org/10.1016/0041-008X(76)90285-4

75. Andrews JE, Courtney KD. Hexachlorobenzene-induced renal maldevelopment in CD-1 mice and CD rats. IARC Sci Publ. 1986; (77):381-391.

76. Lilienthal H, Benthe C, Heinzow B, Winneke G. Impairment of schedule-controlled behavior by pre- and postnatal exposure to hexachlorobenzene in rats. Arch Toxicol. 1996; 70(3-4):174181. http://dx.doi.org/10.1007/s002040050257

77. Vos JG, van Logten MJ, Kreeftenberg JG, Steerenberg PA, Kruizinga W. Effect of hexachlorobenzene on the immune system of rats following combined pre- and postnatal exposure. Drug Chem Toxicol. 1979; 2(1-2):61-76.

http://dx.doi.org/10.3109/01480547908993182

78. Ribas-Fito N, Cardo E, Sala M, Eulalia de Muga M, Mazon C, Verdu A, Kogevinas M, Grimalt JO, Sunyer J. Breastfeeding, exposure to organochlorine compounds, and neurodevelopment in infants. Pediatrics. 2003; 111(5):e580-585.

http://dx.doi.org/10.1542/peds.111.5.e580

79. Ribas-Fito N, Sala M, Cardo E, Mazon C, De Muga ME, Verdu A, Marco E, Grimalt JO, Sunyer J. Organochlorine compounds and concentrations of thyroid stimulating hormone in newborns. Occup Environ Med. 2003; 60(4):301-303. http://dx.doi.org/10.1136/oem.60.4.301

80. Ribas-Fito N, Sala M, Cardo E, Mazon C, De Muga ME, Verdu A, Marco E, Grimalt JO, Sunyer J. Association of hexachlorobenzene and other organochlorine compounds with anthropometric measures at birth. Pediatr Res. 2002; 52(2):163-167.

http://dx.doi.org/10.1203/00006450-200208000-00006

81. Smink A, Ribas-Fito N, Garcia R, Torrent M, Mendez MA, Grimalt JO, Sunyer J. Exposure to hexachlorobenzene during pregnancy increases the risk of overweight in children aged 6 years. Acta Paediatr. 2008; 97(10):1465-1469. http://dx.doi.org/10.1111/j.16512227.2008.00937.x

82. Cabral JRP, Shubik P, Mollner T, Raitano F. Carcinogenic activity of hexacholorobenzene in hamsters. Nature. 1977; 269(5628):510. http://dx.doi.org/10.1038/269510a0

83. Cabral JRP, Mollner T, Raitano F, Shubik P. Carcinogenesis of hexachlorobenzene in mice. Int J Cancer. 1979; 23(1):47-51. http://dx.doi.org/10.1002/ijc.2910230110 
84. Erturk E, Lambrecht RW, Peters HA, Cripps DJ, Gocmen A, Morris CR, Bryan GT. Oncogenicity of hexachlorobenzene. IARC Sci Publ. 1986; (77):417-423.

85. National Toxicology Program (NTP). Report on Carcinogens. 14th ed. Research Triangle Park, NC: United States Department of Health and Human Services, Public Health Service, National Institutes of Health; 2016. https://ntp.niehs.nih.gov/whatwestudy/assessments/cancer/roc/index.html?utm_source=direct\&ut $\underline{\mathrm{m} \_ \text {medium}=\text { prod\&utm campaign }=\text { ntpgolinks\&utm term }=\text { roc } 14}$

86. International Agency for Research on Cancer (IARC). IARC monographs on the evaluation of the carcinogenic risk of chemicals to humans: Chemicals, industrial processes and industries associated with cancer in humans, Vols. 1-29, Suppl. 4. Lyon, France: IARC; 1982.

87. International Agency for Research on Cancer (IARC). IARC monographs on the evaluation of the carcinogenic risks to humans: Overall evaluations of carcinogenicity: An updating of IARC monographs volumes 1 to 42. Lyon, France: IARC; 1987.

88. U. S. Environmental Protection Agency (USEPA). Integrated Risk Information System: Hexachlorobenzene (CAS\# 118-74-1). Washington, DC: U.S. Environmental Protection Agency, Integrated Risk Information System; 2012. https://web.archive.org/web/20120110141038/http://www.epa.gov/iris/subst/0374.htm [Accessed: May 17, 2012]

89. Grimalt JO, Sunyer J, Moreno V, Amaral OC, Sala M, Rosell A, Anto JM, Albaiges J. Risk excess of soft-tissue sarcoma and thyroid cancer in a community exposed to airborne organochlorinated compound mixtures with a high hexachlorobenzene content. Int J Cancer. 1994; 56(2):200-203. http://dx.doi.org/10.1002/ijc.2910560209

90. International Agency for Research on Cancer (IARC). IARC monographs on the evaluation of carcinogenic risks to humans: Some thyrotropic agents, Vol. 79. Lyon, France: IARC; 2001.

91. Brambilla G, Martelli A. Failure of the standard battery of short-term tests in detecting some rodent and human genotoxic carcinogens. Toxicology. 2004; 196(1-2):1-19.

http://dx.doi.org/10.1016/j.tox.2003.11.003

92. Siekel P, Chalupa I, Beno J, Blasko M, Novotny J, Burian J. A genotoxicological study of hexachlorobenzene and pentachloroanisole. Teratog Carcinog Mutagen. 1991; 11(1):55-60. http://dx.doi.org/10.1002/tcm.1770110107

93. Haworth S, Lawlor T, Mortelmans K, Speck W, Zeiger E. Salmonella mutagenicity test results for 250 chemicals. Environ Mutagen. 1983; 5 Suppl 1:3-142.

http://dx.doi.org/10.1002/em.2860050703

94. Gopalaswamy UV, Nair CK. DNA binding and mutagenicity of lindane and its metabolites. Bull Environ Contam Toxicol. 1992; 49(2):300-305. http://dx.doi.org/10.1007/BF00191771

95. Kuroda Y. Genetic and chemical factors affecting chemical mutagenesis in cultured mammalian cells. Basic Life Sci. 1986; 39:359-375. http://dx.doi.org/10.1007/978-1-4684-5182$\underline{5} 31$ 
96. Ennaceur S, Ridha D, Marcos R. Genotoxicity of the organochlorine pesticides 1, 1-dichloro2, 2-bis (p-chlorophenyl) ethylene (DDE) and hexachlorobenzene (HCB) in cultured human lymphocytes. Chemosphere. 2008; 71(7):1335-1339.

http://dx.doi.org/10.1016/j.chemosphere.2007.11.040

97. Canonero R, Campart GB, Mattioli F, Robbiano L, Martelli A. Testing of p-dichlorobenzene and hexachlorobenzene for their ability to induce DNA damage and micronucleus formation in primary cultures of rat and human hepatocytes. Mutagenesis. 1997; 12(1):35-40. http://dx.doi.org/10.1093/mutage/12.1.35

98. Salmon ML, Madanagopal SG, Blando R, Berner J, Williams K. Effects of hexachlorobenzene on embryonic mammalian cells. Toxicol In Vitro. 2002; 16(5):539-548. http://dx.doi.org/10.1016/S0887-2333(02)00054-1

99. Simon GS, Tardiff RG, Borzelleca JF. Failure of hexachlorobenzene to induce dominant lethal mutations in the rat. Toxicol Appl Pharmacol. 1979; 47(2):415-419. http://dx.doi.org/10.1016/0041-008X(79)90337-5

100. Khera KS. Tetratogenicity and dominant lethal studies on hexachlorobenzene in rats. Food Cosmet Toxicol. 1974; 12(4):471-477. http://dx.doi.org/10.1016/0015-6264(74)90060-1

101. Gustafson DL, Long ME, Thomas RS, Benjamin SA, Yang RS. Comparative hepatocarcinogenicity of hexachlorobenzene, pentachlorobenzene, 1,2,4,5-tetrachlorobenzene, and 1,4-dichlorobenzene: Application of a medium-term liver focus bioassay and molecular and cellular indices. Toxicol Sci. 2000; 53(2):245-252. http://dx.doi.org/10.1093/toxsci/53.2.245

102. Linko P, Yeowell HN, Gasiewicz TA, Goldstein JA. Induction of cytochrome P-450 isozymes by hexachlorobenzene in rats and aromatic hydrocarbon (Ah)-responsive mice. $\mathrm{J}$ Biochem Toxicol. 1986; 1(2):95-107. http://dx.doi.org/10.1002/jbt.2570010209

103. Hahn ME, Gasiewicz TA, Linko P, Goldstein JA. The role of the Ah locus in hexachlorobenzene-induced porphyria. Studies in congenic C57BL/6J mice. Biochem J. 1988; 254(1):245-254. http://dx.doi.org/10.1042/bj2540245

104. Randi AS, Cocca C, Carbone V, Nunez M, Croci M, Gutierrez A, Bergoc R, Kleiman de Pisarev DL. Hexachlorobenzene is a tumor co-carcinogen and induces alterations in insulingrowth factors signaling pathway in the rat mammary gland. Toxicol Sci. 2006; 89(1):83-92. http://dx.doi.org/10.1093/toxsci/kfj023

105. Pena D, Pontillo C, Garcia MA, Cocca C, Alvarez L, Chiappini F, Bourguignon N, Frahm I, Bergoc R, Kleiman de Pisarev D et al. Alterations in c-Src/HER1 and estrogen receptor alpha signaling pathways in mammary gland and tumors of hexachlorobenzene-treated rats. Toxicology. 2012; 293(1-3):68-77. http://dx.doi.org/10.1016/j.tox.2011.12.012

106. National Toxicology Program (NTP). NTP toxicology and carcinogenesis studies of 3,3',4,4',5-pentachlorobiphenyl (PCB 126) (CAS No. 57465-28-8) in female Harlan SpragueDawley rats (gavage studies). Research Triangle Park, NC: U.S. Department of Health and Human Services, Public Health Service, National Institutes of Health; 2006. Technical Report No. 520. 
107. Kociba RJ, Keyes DG, Beyer JE, Carreon RM, Wade CE, Dittenber DA, Kalnins RP, Frauson LE, Park CN, Barnard SD et al. Results of a two-year chronic toxicity and oncogenicity study of 2,3,7,8-tetrachlorodibenzo-p-dioxin in rats. Toxicol Appl Pharmacol. 1978; 46(2):279303. http://dx.doi.org/10.1016/0041-008X(78)90075-3

108. National Toxicology Program (NTP). NTP technical report on the toxicology and carcinogenesis studies of 2,3,7,8-tetrachlorodibenzo-p-dioxin (TCDD) (CAS No. 1746-01-6) in female Harlan Sprague-Dawley rats (gavage studies). Research Triangle Park, NC: U.S. Department of Health and Human Services, Public Health Service, National Institutes of Health; 2006. Technical Report No. 521.

109. Boorman GA, Hickman RL, Davis GW, Rhodes LS, White NW, Griffin TA, Mayo J, Hamm TE, Jr. Serological titers to murine viruses in 90 day and 2 year studies. In: Complications of Viral and Mycoplasmal Infections in Rodents to Toxicology Research and Testing. Washington, DC: Hemisphere Publishing Corporation; 1986. p. 11-23.

110. Rao GN, Piegorsch WW, Crawford DD, Edmondson J, Haseman JK. Influence of viral infections on body weight, survival, and tumor prevalence of B6C3F1 (C57BL/6N x C3H/HeN) mice in carcinogenicity studies. Fundam Appl Toxicol. 1989; 13(1):156-164. http://dx.doi.org/10.1016/0272-0590(89)90315-1

111. Rao GN, Haseman JK, Edmondson J. Influence of viral infections on body weight, survival, and tumor prevalence in Fischer 344/NCr rats on two-year studies. Lab Anim Sci. 1989; 39(5):389-393.

112. Van den Berg M, Birnbaum LS, Denison M, De Vito M, Farland W, Feeley M, Fiedler H, Hakansson H, Hanberg A, Haws L et al. The 2005 World Health Organization reevaluation of human and mammalian toxic equivalency factors for dioxins and dioxin-like compounds. Toxicol Sci. 2006; 93(2):223-241. http://dx.doi.org/10.1093/toxsci/kfl055

113. Lambrecht RW, Erturk E, Grunden EE, Peters HA, Morns CR, Bryan GT. Hepatocarcinogenicity of chronically administered hexachlorobenzene in rats. Fed Proc. 1983; 42:786.

114. Lambrecht RW, Erturk E, Grunden EE, Peters HA, Morns CR, Bryan GT. Renal tumors in rats chronically exposed to hexachlorobenzene. Proc Am Assoc Cancer Res. 1983; 24:59.

115. Pearce RE, McIntyre CJ, Madan A, Sanzgiri U, Draper AJ, Bullock PL, Cook DC, Burton LA, Latham J, Nevins C et al. Effects of freezing, thawing, and storing human liver microsomes on cytochrome P450 activity. Arch Biochem Biophys. 1996; 331(2):145-169.

http://dx.doi.org/10.1006/abbi.1996.0294

116. Maronpot RR, Boorman GA. Interpretation of rodent hepatocellular proliferative alterations and hepatocellular tumors in chemical safety assessment. Toxicol Pathol. 1982; 10(2):71-78. http://dx.doi.org/10.1177/019262338201000210

117. Boorman GA, Haseman JK, Waters MD, Hardisty JF, Sills RC. Quality review procedures necessary for rodent pathology databases and toxicogenomic studies: The National Toxicology Program experience. Toxicol Pathol. 2002; 30(1):88-92. 10.1080/01926230252824752 
118. Gart JJ, Chu KC, Tarone RE. Statistical issues in interpretation of chronic bioassay tests for carcinogenicity. J Natl Cancer Inst. 1979; 62(4):957-974.

119. Armitage P. Statistical methods in medical research. Blackwell, Oxford; 1971.

120. Dunnett CW. A multiple comparison procedure for comparing several treatments with a control. J Am Stat Assoc. 1955; 50(272):1096-1121.

http://dx.doi.org/10.1080/01621459.1955.10501294

121. Williams DA. A test for differences between treatment means when several dose levels are compared with a zero dose control. Biometrics. 1971; 27(1):103-117.

http://dx.doi.org/10.2307/2528930

122. Williams DA. The comparison of several dose levels with a zero dose control. Biometrics. 1972; 28(2):519-531. http://dx.doi.org/10.2307/2556164

123. Shirley E. A non-parametric equivalent of Williams' test for contrasting increasing dose levels of a treatment. Biometrics. 1977; 33(2):386-389. http://dx.doi.org/10.2307/2529789

124. Williams DA. A note on Shirley's nonparametric test for comparing several dose levels with a zero-dose control. Biometrics. 1986; 42(1):183-186. http://dx.doi.org/10.2307/2531254

125. Dunn OJ. Multiple comparisons using rank sums. Technometrics. 1964; 6(3):241-252. http://dx.doi.org/10.1080/00401706.1964.10490181

126. Jonckheere AR. A distribution-free k-sample test against ordered alternatives. Biometrika. 1954; 41:133-145. http://dx.doi.org/10.1093/biomet/41.1-2.133

127. Dixon WJ, Massey FJ, Jr. Introduction to statistical analysis, 2nd ed. New York, NY: McGraw-Hill Book Company; 1957. p. 276-278, 412.

128. Code of Federal Regulations (CFR). 21:Part 58.

129. National Toxicology Program (NTP). TOX-77: Toxicity report tables \& curves: Pathology tables, survival and growth curves from NTP short-term and toxicokinetics studies. Research Triangle Park, NC: U.S. Department of Health and Human Services, Public Health Service, National Institutes of Health; 2020. https://doi.org/10.22427/NTP-DATA-TOX-77

130. Long PH, Herbert RA, Nyska A. Hexachlorobenzene-induced incisor degeneration in Sprague-Dawley rats. Toxicol Pathol. 2004; 32(1):35-40.

http://dx.doi.org/10.1080/01926230490260871

131. DeVito MJ, Diliberto JJ, Ross DG, Menache MG, Birnbaum LS. Dose-response relationships for polyhalogenated dioxins and dibenzofurans following subchronic treatment in mice. I. CYP1A1 and CYP1A2 enzyme activity in liver, lung, and skin. Toxicol Appl Pharmacol. 1997; 147(2):267-280. http://dx.doi.org/10.1006/taap.1997.8261

132. Kuiper-Goodman T, Grant DL, Moodie CA, Korsrud GO, Munro IC. Subacute toxicity of hexachlorobenzene in the rat. Toxicol Appl Pharmacol. 1977; 40(3):529-549. http://dx.doi.org/10.1016/0041-008X(77)90078-3 
133. Smith AG, Cabral JR. Liver-cell tumours in rats fed hexachlorobenzene. Cancer Lett. 1980; 11(2):169-172. http://dx.doi.org/10.1016/0304-3835(80)90108-1

134. Schielen P, Den Besten C, Vos JG, Van Bladeren PJ, Seinen W, Bloksma N. Immune effects of hexachlorobenzene in the rat: Role of metabolism in a 13-week feeding study. Toxicol Appl Pharmacol. 1995; 131(1):37-43. http://dx.doi.org/10.1006/taap.1995.1044

135. Stockinger B, Meglio PD, Gialitakis M, Duarte JH. The aryl hydrocarbon receptor: Multitasking in the immune system. Annu Rev Immunol. 2014; 32(1):403-432. https://doi.org/10.1146/annurev-immunol-032713-120245

136. Miret N, Rico-Leo E, Pontillo C, Zotta E, Fernandez-Salguero P, Randi A. A dioxin-like compound induces hyperplasia and branching morphogenesis in mouse mammary gland, through alterations in TGF-betal and aryl hydrocarbon receptor signaling. Toxicol Appl Pharmacol. 2017; 334:192-206. http://dx.doi.org/10.1016/j.taap.2017.09.012

137. Miret NV, Pontillo CA, Zarate LV, Kleiman de Pisarev D, Cocca C, Randi AS. Impact of endocrine disruptor hexachlorobenzene on the mammary gland and breast cancer: The story thus far. Environ Res. 2019; 173:330-341. http://dx.doi.org/10.1016/j.envres.2019.03.054

138. Kiukkonen A, Viluksela M, Sahlberg C, Alaluusua S, Tuomisto JT, Tuomisto J, Lukinmaa PL. Response of the incisor tooth to 2,3,7,8-tetrachlorodibenzo-p-dioxin in a dioxin-resistant and a dioxin-sensitive rat strain. Toxicol Sci. 2002; 69(2):482-489. http://dx.doi.org/10.1093/toxsci/69.2.482

139. Sahlberg C, Pohjanvirta R, Gao Y, Alaluusua S, Tuomisto J, Lukinmaa PL. Expression of the mediators of dioxin toxicity, aryl hydrocarbon receptor (AHR) and the AHR nuclear translocator (ARNT), is developmentally regulated in mouse teeth. Int J Dev Biol. 2002; 46(3):295-300.

140. Schmidt CK, Hoegberg P, Fletcher N, Nilsson CB, Trossvik C, Håkansson H, Nau H. 2,3,7,8-Tetrachlorodibenzo-p-dioxin (TCDD) alters the endogenous metabolism of all-transretinoic acid in the rat. Arch Toxicol. 2003; 77(7):371-383. https://doi.org/10.1007/s00204-003$\underline{0457-8}$

141. Nilsson CB, Håkansson H. The retinoid signaling system - A target in dioxin toxicity. Crit Rev Toxicol. 2002; 32(3):211-232. https://doi.org/10.1080/20024091064228

142. Alaluusua S, Lukinmaa PL, Pohjanvirta R, Unkila M, Tuomisto J. Exposure to 2, 3, 7, 8tetrachlorodibenzo-para-dioxin leads to defective dentin formation and pulpal perforation in rat incisor tooth. Toxicology. 1993; 81(1):1-13. http://dx.doi.org/10.1016/0300-483X(93)90152-I

143. Alaluusua S, Lukinmaa PL, Koskimies M, Pirinen S, Holtta P, Kallio M, Holttinen T, Salmenpera L. Developmental dental defects associated with long breast feeding. Eur J Oral Sci. 1996; 104(5-6):493-497. http://dx.doi.org/10.1111/j.1600-0722.1996.tb00131.x

144. Alaluusua S, Lukinmaa PL, Torppa J, Tuomisto J, Vartiainen T. Developing teeth as biomarker of dioxin exposure. Lancet. 1999; 353(9148):206. http://dx.doi.org/10.1016/S0140$\underline{6736(05) 77214-7}$ 
145. Holtta P, Kiviranta H, Leppaniemi A, Vartiainen T, Lukinmaa PL, Alaluusua S. Developmental dental defects in children who reside by a river polluted by dioxins and furans. Arch Environ Health. 2001; 56(6):522-528. http://dx.doi.org/10.1080/00039890109602901

146. Kattainen H, Tuukkanen J, Simanainen U, Tuomisto JT, Kovero O, Lukinmaa PL, Alaluusua S, Tuomisto J, Viluksela M. In utero/lactational 2,3,7,8-tetrachlorodibenzo-p-dioxin exposure impairs molar tooth development in rats. Toxicol Appl Pharmacol. 2001; 174(3):216224. http://dx.doi.org/10.1006/taap.2001.9216

147. Lukinmaa PL, Sahlberg C, Leppaniemi A, Partanen A-M, Kovero O, Pohjanvirta R, Tuomisto J, Alaluusua S. Arrest of rat molar tooth development by lactational exposure to 2, 3, 7, 8-tetrachlorodibenzo-p-dioxin. Toxicol Appl Pharmacol. 2001; 173(1):38-47. http://dx.doi.org/10.1006/taap.2001.9155

148. van Raaij JA, Frijters CM, van den Berg KJ. Hexachlorobenzene-induced hypothyroidism. Involvement of different mechanisms by parent compound and metabolite. Biochem Pharmacol. 1993; 46(8):1385-1391. http://dx.doi.org/10.1016/0006-2952(93)90103-4

149. Chiappini F, Alvarez L, Lux-Lantos V, Randi AS, Kleiman de Pisarev DL. Hexachlorobenzene triggers apoptosis in rat thyroid follicular cells. Toxicol Sci. 2009; 108(2):301-310. http://dx.doi.org/10.1093/toxsci/kfp016

150. Den Besten C, Bennik MHJ, Bruggeman I, Schielen P, Kuper F, Brouwer A, Koeman JH, Vos JG, Vanbladeren PJ. The role of oxidative metabolism in hexachlorobenzene-induced porphyria and thyroid hormone homeostasis: A comparison with pentachlorobenzene in a 13week feeding study. Toxicol Appl Pharmacol. 1993; 119(2):181-194.

http://dx.doi.org/10.1006/taap.1993.1059

151. Ãlvarez L, Hernandez S, Martinez-de-Mena R, Kolliker-Frers R, Obregon MJ, De Pisarev DLK. The role of type I and type II 5' deiodinases on hexachlorobenzene-induced alteration of the hormonal thyroid status. Toxicology. 2005; 207(3):349-362.

http://dx.doi.org/10.1016/j.tox.2004.10.006

152. Vanbirgelen AP, Vanderkolk J, Fase KM, Bol I, Poiger H, Vandenberg M, Brouwer A. Toxic potency of 2,3,3',4,4',5-hexachlorobiphenyl relative to and in combination with 2,3,7,8tetrachlorodibenzo-p-dioxin in a subchronic feeding study in the rat. Toxicol Appl Pharmacol. 1994; 126(2):202-213. http://dx.doi.org/10.1006/taap.1994.1109

153. Schwarz M, Buchmann A, Stinchcombe S, Kalkuhl A, Bock K. Ah receptor ligands and tumor promotion: Survival of neoplastic cells. Toxicol Lett. 2000; 112-113:69-77.

http://dx.doi.org/10.1016/S0378-4274(99)00247-7

154. Elcombe CR, Peffer RC, Wolf DC, Bailey J, Bars R, Bell D, Cattley RC, Ferguson SS, Geter D, Goetz A et al. Mode of action and human relevance analysis for nuclear receptormediated liver toxicity: A case study with phenobarbital as a model constitutive androstane receptor (CAR) activator. Crit Rev Toxicol. 2014; 44(1):64-82.

https://doi.org/10.3109/10408444.2013.835786

155. Randi AS, Sanchez MS, Alvarez L, Cardozo J, Pontillo C, Kleiman de Pisarev DL. Hexachlorobenzene triggers AhR translocation to the nucleus, c-Src activation and EGFR 
transactivation in rat liver. Toxicol Lett. 2008; 177(2):116-122.

http://dx.doi.org/10.1016/j.toxlet.2008.01.003

156. de Tomaso Portaz AC, Caimi GR, Sánchez M, Chiappini F, Randi AS, de Pisarev DLK, Alvarez L. Hexachlorobenzene induces cell proliferation, and aryl hydrocarbon receptor expression (AhR) in rat liver preneoplastic foci, and in the human hepatoma cell line HepG2. AhR is a mediator of ERK1/2 signaling, and cell cycle regulation in HCB-treated HepG2 cells. Toxicology. 2015; 336:36-47. http://dx.doi.org/10.1016/j.tox.2015.07.013

157. Garcia MA, Pena D, Ãlvarez L, Cocca C, Pontillo C, Bergoc R, de Pisarev DK, Randi A. Hexachlorobenzene induces cell proliferation and IGF-I signaling pathway in an estrogen receptor alpha-dependent manner in MCF-7 breast cancer cell line. Toxicol Lett. 2010; 192(2):195-205. http://dx.doi.org/10.1016/j.toxlet.2009.10.026

158. Kazantseva YA, Pustylnyak YA, Pustylnyak VO. Role of nuclear constitutive androstane receptor in regulation of hepatocyte proliferation and hepatocarcinogenesis. Biochemistry (Mosc). 2016; 81(4):338-347. http://dx.doi.org/10.1134/s0006297916040040

159. Kolaya KL, Stevenson DE, Walborg EF, Jr., Klaunig JE. Dose dependence of phenobarbital promotion of preneoplastic hepatic lesions in $\mathrm{F} 344$ rats and $\mathrm{B} 6 \mathrm{C} 3 \mathrm{~F} 1$ mice: effects on DNA synthesis and apoptosis. Carcinogenesis. 1996; 17(5):947-954.

https://doi.org/10.1093/carcin/17.5.947

160. Goldstein JA, Linko P, Hahn ME, Gasiewicz TA, Yeowell HN. Structure-activity relationships of chlorinated benzenes as inducers of hepatic cytochrome P-450 isozymes in the rat. IARC Sci Publ. 1986; (77):519-526.

161. Schmidt JV, Su GH, Reddy JK, Simon MC, Bradfield CA. Characterization of a murine Ahr null allele: Involvement of the Ah receptor in hepatic growth and development. Proc Natl Acad Sci U S A. 1996; 93(13):6731-6736. http://dx.doi.org/10.1073/pnas.93.13.6731

162. Paolini M, Mesirca R, Pozzetti L, Sapone A, Cantelli-Forti G. Induction of CYP2B1 mediated pentoxyresorufin O-dealkylase activity in different species, sex and tissue by prototype 2B1-inducers. Chem Biol Interact. 1995; 95(1-2):127-139. http://dx.doi.org/10.1016/00092797(94)03352-8

163. Ingebrigtsen K, Nafstad I. Distribution and elimination of 14C-hexachlorobenzene after single oral exposure in the male rat. Acta Pharmacol Toxicol (Copenh). 1983; 52(4):254-260. https://doi.org/10.1111/j.1600-0773.1983.tb01096.x

164. Iatropoulos MJ, Milling A, Müller WF, Nohynek G, Rozman K, Coulston F, Korte F. Absorption, transport and organotropism of dichlorobiphenyl (DCB), Dieldrin, and hexachlorobenzene (HCB) in rats. Environ Res. 1975; 10(3):384-389. https://doi.org/10.1016/0013-9351(75)90033-X

165. Muller WF, Scheunert I, Rozman K, Kogel W, Freitag D, Richter E, Coulston F, Korte F. Comparative metabolism of hexachlorobenzene and pentachloronitrobenzene in plants, rats, and rhesus monkeys. Ecotoxicol Environ Saf. 1978; 2(3-4):437-445.

http://dx.doi.org/10.1016/S0147-6513(78)80017-7 
166. Morita M, Oishi S. Clearance and tissue distribution of hexachlorobenzene in rats. Bull Environ Contam Toxicol. 1975; 14(3):313-318. https://doi.org/10.1007/BF01685643

167. Viluksela M, Raasmaja A, Lebofsky M, Stahl BU, Rozman KK. Tissue-specific effects of 2,3,7,8-tetrachlorodibenzo-p-dioxin (TCDD) on the activity of 5'-deiodinases I and II in rats. Toxicol Lett. 2004; 147(2):133-142. http://dx.doi.org/10.1016/j.toxlet.2003.10.025

168. Giribaldi L, Chiappini F, Pontillo C, Randi AS, de Pisarev DLK, Alvarez L. Hexachlorobenzene induces deregulation of cellular growth in rat liver. Toxicology. 2011; 289(1):19-27. http://dx.doi.org/10.1016/j.tox.2011.07.004

169. Bock KW, Kohle C. Ah receptor-and TCDD-mediated liver tumor promotion: Clonal selection and expansion of cells evading growth arrest and apoptosis. Biochem Pharmacol. 2005; 69(10):1403-1408. http://dx.doi.org/10.1016/j.bcp.2005.02.004

170. Pouchert CJ. 1985. The Aldrich Library of FT-IR Spectra: Vol. 1, p. 1016, spectrum B. Milwaukee, WI: Aldrich Chemical Company, Inc. 


\section{Appendix A. Chemical Characterization and Dose Formulation Studies}

\section{Table of Contents}

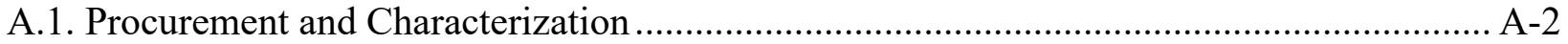

A.2. Preparation and Analysis of Dose Formulations....................................................... A-2

\section{Tables}

Table A-1. Gas Chromatography Systems Used in the Three-month Gavage Study of Hexachlorobenzene

Table A-2. Preparation and Storage of Dose Formulations in the Three-month Gavage Study of Hexachlorobenzene

\section{Figures}

Figure A-1. Infrared Absorption Spectrum of Hexachlorobenzene

Figure A-2. Mass Spectrum of Hexachlorobenzene 


\section{A.1. Procurement and Characterization}

\section{A.1.1. Hexachlorobenzene}

Hexachlorobenzene (HCB) was obtained from Aldrich Chemical Company (Milwaukee, WI) in one lot $(03915 \mathrm{CU})$ that was used in the 3-month study. Identity and purity analyses were conducted by the analytical chemistry laboratory at Midwest Research Institute (MRIGlobal, Kansas City, MO); additional identity analyses were conducted by the study laboratory at Battelle (Columbus, OH). One additional lot (08526EF) was procured from Aldrich Chemical Company by the analytical chemistry laboratory solely for dose formulation stability studies and was not used in the 3-month animal study. Reports on analyses performed in support of the HCB study are on file at the National Institute of Environmental Health Sciences.

Lot $03915 \mathrm{CU}$ of the chemical, a white powder, was identified as HCB by the analytical chemistry laboratory using infrared (IR) spectroscopy and gas chromatography (GC) coupled with mass spectrometry (MS). The study laboratory confirmed the identity of the test article by IR spectroscopy. IR and MS spectra were consistent with the structure of HCB and comparable to literature spectra ${ }^{170}$ of HCB. Representative IR and MS spectra are presented in Figure A-1 and Figure A-2, respectively.

The purity of lot $03915 \mathrm{CU}$ was determined by GC with flame ionization detection (GC/FID) using System A (Table A-1). The purity assay indicated one major peak and one impurity with a peak area equal to $0.05 \%$ of the total peak area. The overall purity of lot $03915 \mathrm{CU}$ was determined to be $>99 \%$.

After the scheduled termination of the animals, bulk chemical reanalysis was performed by the study laboratory using GC/FID by System B, and no degradation of the bulk chemical was detected. To ensure stability, the bulk chemical was stored at room temperature in an amber glass bottle.

\section{A.1.2. Formulation Materials}

United States Pharmacopeia (USP)-grade corn oil was obtained from Spectrum Quality Products (Gardena, CA) in two lots and was used with one lot of USP-grade acetone (Spectrum Quality Products) as the vehicle in the 3-month gavage study. The identity of the acetone was confirmed by the study laboratory using IR spectroscopy prior to its use. Purity of the acetone was determined to be $\geq 99.9 \%$ by the study laboratory using GC/FID by System C. The corn oil was analyzed twice by the study laboratory for peroxide levels by potentiometric titration; both measured values were below the $3 \mathrm{mEq} / \mathrm{kg}$ rejection criterion.

\section{A.2. Preparation and Analysis of Dose Formulations}

The dose formulations were prepared by mixing stock solutions of HCB in acetone with corn oil or by mixing HCB with the vehicle (corn oil:acetone [99:1]) to achieve the required concentrations (Table A-2). The dose formulations were stored in amber glass bottles sealed with Teflon ${ }^{\circledR}$-lined lids at room temperature for up to 34 days.

The study laboratory determined that a $10 \mathrm{mg} / \mathrm{mL}$ dose formulation in corn oil:acetone (99:1) was gavagable using a 20 -gauge needle. 
Homogeneity studies of the 0.012 and $10.0 \mathrm{mg} / \mathrm{mL}$ dose formulations in corn oil containing $1 \%$ acetone were performed by the study laboratory using $\mathrm{GC}$ with electron capture detection (ECD) by System D (Table A-1). Stability studies of a $1 \mu \mathrm{g} / \mathrm{mL}$ dose formulation made with lot $08526 \mathrm{EF}$ dissolved in $100 \%$ corn oil were performed by the analytical chemistry laboratory using a GC/ECD system similar to System D. Homogeneity was confirmed, and stability for at least 35 days was confirmed for dose formulations stored in sealed containers in the dark at $5^{\circ} \mathrm{C}$ and $25^{\circ} \mathrm{C}$ and for at least 3 hours under simulated animal room conditions.

Periodic analyses of the dose formulations of HCB were conducted by the study laboratory using GC/ECD by System D. During the 3-month study, the dose formulations were analyzed at the beginning, midpoint, and termination; all 21 dose formulations were within $10 \%$ of the target concentrations (Table A-3). Animal room samples of these dose formulations were also analyzed; 20 of 21 animal room samples were within $10 \%$ of the target concentrations.

Table A-1. Gas Chromatography Systems Used in the Three-month Gavage Study of Hexachlorobenzene $e^{a}$

\begin{tabular}{|c|c|c|c|}
\hline Detection System & Column & Carrier Gas & $\begin{array}{c}\text { Oven Temperature } \\
\text { Program }\end{array}$ \\
\hline \multicolumn{4}{|l|}{ System A } \\
\hline Flame ionization & $\begin{array}{l}\text { DB-5, } 30 \mathrm{~m} \times 0.53 \mathrm{~mm}, \\
1.5-\mu \mathrm{m} \text { film thickness } \\
\text { (Agilent Technologies Inc., } \\
\text { Santa Clara, CA) }\end{array}$ & Helium at $10 \mathrm{~mL} /$ minute & $\begin{array}{l}50^{\circ} \mathrm{C} \text { for } 5 \text { minutes, then } \\
10^{\circ} \mathrm{C} / \text { minute to } 250^{\circ} \mathrm{C} \text {, held } \\
\text { for } 20 \text { minutes }\end{array}$ \\
\hline \multicolumn{4}{|l|}{ System B } \\
\hline Flame ionization & $\begin{array}{l}\mathrm{RTX}^{\circledR}-5,15 \mathrm{~m} \times 0.53 \mathrm{~mm}, \\
1.0-\mu \mathrm{m} \text { film thickness } \\
\text { (Restek Corporation, } \\
\text { Bellafonte, PA) }\end{array}$ & Helium at $\sim 10 \mathrm{~mL} /$ minute & Isothermal at $165^{\circ} \mathrm{C}$ \\
\hline \multicolumn{4}{|l|}{ System C } \\
\hline Flame ionization & $\begin{array}{l}\text { SUPELCOWAX }{ }^{\mathrm{TM}} 10, \\
30 \mathrm{~m} \times 0.53 \mathrm{~mm}, 0.5-\mu \mathrm{m} \\
\text { film thickness (Supelco, } \\
\text { Inc., Bellefonte, PA) }\end{array}$ & Helium at $\sim 10 \mathrm{~mL} /$ minute & $\begin{array}{l}40^{\circ} \mathrm{C} \text { for } 5 \text { minutes, then } \\
10^{\circ} \mathrm{C} / \text { minute to } 220^{\circ} \mathrm{C}\end{array}$ \\
\hline \multicolumn{4}{|l|}{ System D } \\
\hline Electron capture & $\begin{array}{l}\mathrm{RTX}^{\circledR}-5,15 \mathrm{~m} \times 0.53 \mathrm{~mm}, \\
1.0-\mu \mathrm{m} \text { film thickness } \\
\text { (Restek Corporation) }\end{array}$ & Helium at $\sim 10 \mathrm{~mL} /$ minute & $\begin{array}{l}170^{\circ} \mathrm{C} \text { for } 9 \text { minutes, then } \\
30^{\circ} \mathrm{C} / \text { minute to } 250^{\circ} \mathrm{C} \text {, held } \\
\text { for } 8 \text { minutes }\end{array}$ \\
\hline
\end{tabular}

aThe gas chromatographs were manufactured by Hewlett-Packard (Palo Alto, CA). 
Table A-2. Preparation and Storage of Dose Formulations in the Three-month Gavage Study of Hexachlorobenzene

\section{Three-month Study}

\section{Preparation}

To prepare the corn oil:acetone (99:1) vehicle, a specified amount of acetone was measured using a volumetric pipette and transferred into a calibrated glass mixing container approximately half-filled with corn oil. The contents of the container were diluted to volume with corn oil, and the container was capped, shaken vigorously, sonicated for approximately 90 minutes (allowing the temperature of the sonicator to reach approximately $40^{\circ} \mathrm{C}$ ) with intermittent vigorous shaking, and shaken vigorously after sonication was complete.

To prepare the 0.012 and $0.04 \mathrm{mg} / \mathrm{mL}$ dose formulations, stock solutions were made by weighing 60 and $200 \mathrm{mg}$ of HCB, respectively, into individual $50 \mathrm{~mL}$ volumetric flasks, adding approximately $25 \mathrm{~mL}$ of acetone, capping the flask and shaking to mix, then diluting the contents to volume with acetone, capping, and shaking to mix. The flask was then vortexed for approximately 2 minutes, sonicated until the HCB was in solution, and inverted at least 10 times. Five $\mathrm{mL}$ of stock solution was measured with a volumetric pipette and transferred into a $500 \mathrm{~mL}$ glass mixing container approximately half-filled with corn oil. The container was capped and shaken vigorously, and the contents were diluted to final volume with corn oil. The container was recapped and then shaken and sonicated as described for the corn oil:acetone (99:1) vehicle.

For the $0.12,0.4,1.2,4$, and $10 \mathrm{mg} / \mathrm{mL}$ dose formulations, the appropriate amount of HCB was weighed in a weigh boat and transferred into a $500 \mathrm{~mL}$ glass mixing container approximately half-filled with corn oil, while tapping the weigh boat to transfer as much of the test article as possible. Five $\mathrm{mL}$ of acetone was measured using a glass volumetric pipette and transferred into the container. The container was capped and shaken vigorously, and the contents were diluted to final volume with corn oil. The container was recapped and then shaken and sonicated as described for the corn oil:acetone (99:1) vehicle.

\section{Chemical Lot Number}

$03915 \mathrm{CU}$

\section{Maximum Storage Time}

34 days

\section{Storage Conditions}

Stored in amber glass bottles sealed with Teflon ${ }^{\circledR}$-lined lids at room temperature.

\section{Study Laboratory}

Battelle (Columbus, OH) 
Hexachlorobenzene, NTP TOX 77

Table A-3. Results of Analyses of Dose Formulations Administered to Female Rats in the Three-month Gavage Study of Hexachlorobenzene

\begin{tabular}{|c|c|c|c|c|}
\hline Date Prepared & Date Analyzed & $\begin{array}{c}\text { Target } \\
\text { Concentration } \\
(\mathrm{mg} / \mathrm{mL})\end{array}$ & $\begin{array}{c}\text { Determined } \\
\text { Concentration } \\
(\mathrm{mg} / \mathrm{mL})\end{array}$ & $\begin{array}{c}\text { Difference from } \\
\text { Target }(\%)\end{array}$ \\
\hline \multirow[t]{14}{*}{ January 2-3, 2001} & January 4-8, 2001 & 0.012 & 0.01157 & -4 \\
\hline & & 0.04 & 0.03697 & -8 \\
\hline & & 0.12 & 0.1210 & +1 \\
\hline & & 0.4 & 0.4008 & 0 \\
\hline & & 1.2 & 1.197 & 0 \\
\hline & & 4 & 4.325 & +8 \\
\hline & & 10 & 10.64 & +6 \\
\hline & February $8-9,2001^{\text {b }}$ & 0.012 & 0.01166 & -3 \\
\hline & & 0.04 & 0.03688 & -8 \\
\hline & & 0.12 & 0.1175 & -2 \\
\hline & & 0.4 & 0.3948 & -1 \\
\hline & & 1.2 & 1.180 & -2 \\
\hline & & 4 & 3.870 & -3 \\
\hline & & 10 & 9.844 & -2 \\
\hline \multirow[t]{14}{*}{ February 26, 2001} & February 28-March 1, 2001 & 0.012 & 0.01138 & -5 \\
\hline & & 0.04 & 0.03860 & -4 \\
\hline & & 0.12 & 0.1239 & +3 \\
\hline & & 0.4 & 0.3946 & -1 \\
\hline & & 1.2 & 1.196 & 0 \\
\hline & & 4 & 3.960 & -1 \\
\hline & & 10 & 9.735 & -3 \\
\hline & April 3-4, 2001 ${ }^{\mathrm{b}}$ & 0.012 & 0.01157 & -4 \\
\hline & & 0.04 & 0.03793 & -5 \\
\hline & & 0.12 & 0.1173 & -2 \\
\hline & & 0.4 & 0.3888 & -3 \\
\hline & & 1.2 & 1.191 & -1 \\
\hline & & 4 & 3.946 & -1 \\
\hline & & 10 & 9.935 & -1 \\
\hline
\end{tabular}


Hexachlorobenzene, NTP TOX 77

\begin{tabular}{lcccc}
\hline Date Prepared & Date Analyzed & $\begin{array}{c}\text { Target } \\
\text { Concentration } \\
(\mathbf{m g} / \mathbf{m L})\end{array}$ & $\begin{array}{c}\text { Determined } \\
\text { Concentration } \\
(\mathbf{m g} / \mathbf{m L})\end{array}$ & $\begin{array}{c}\text { Difference from } \\
\text { Target (\%) }\end{array}$ \\
\hline March 22, 2001 & March 27, 2001 & 0.012 & 0.01255 & +5 \\
& 0.04 & 0.03698 & -8 \\
& 0.12 & 0.1146 & -5 \\
& 0.4 & 0.3893 & -3 \\
& April 17-18, 2001 & 1.2 & 1.164 & -3 \\
& 4 & 4.164 & +4 \\
& 10 & 9.494 & -5 \\
& 0.012 & 0.01189 & -1 \\
& 0.04 & 0.03959 & -1 \\
& 0.12 & 0.1059 & +1 \\
& 0.4 & 0.4033 & +5 \\
& 1.2 & 1.256 & +2 \\
& 4 & 4.060 & +4 \\
\hline
\end{tabular}

${ }^{2}$ Results of duplicate analyses. Dosing volume $=2.5 \mathrm{~mL} / \mathrm{kg} ; 0.012 \mathrm{mg} / \mathrm{mL}=0.03 \mathrm{mg} / \mathrm{kg}, 0.04 \mathrm{mg} / \mathrm{mL}=0.1 \mathrm{mg} / \mathrm{kg}$,

$0.12 \mathrm{mg} / \mathrm{mL}=0.3 \mathrm{mg} / \mathrm{kg}, 0.4 \mathrm{mg} / \mathrm{mL}=1 \mathrm{mg} / \mathrm{kg}, 1.2 \mathrm{mg} / \mathrm{mL}=3 \mathrm{mg} / \mathrm{kg}, 4 \mathrm{mg} / \mathrm{mL}=10 \mathrm{mg} / \mathrm{kg}, 10 \mathrm{mg} / \mathrm{mL}=25 \mathrm{mg} / \mathrm{kg}$.

${ }^{\mathrm{b}}$ Animal room samples.

${ }^{\mathrm{c} R e s u l t s}$ of triplicate analyses (mean \pm standard deviation). 
Hexachlorobenzene, NTP TOX 77

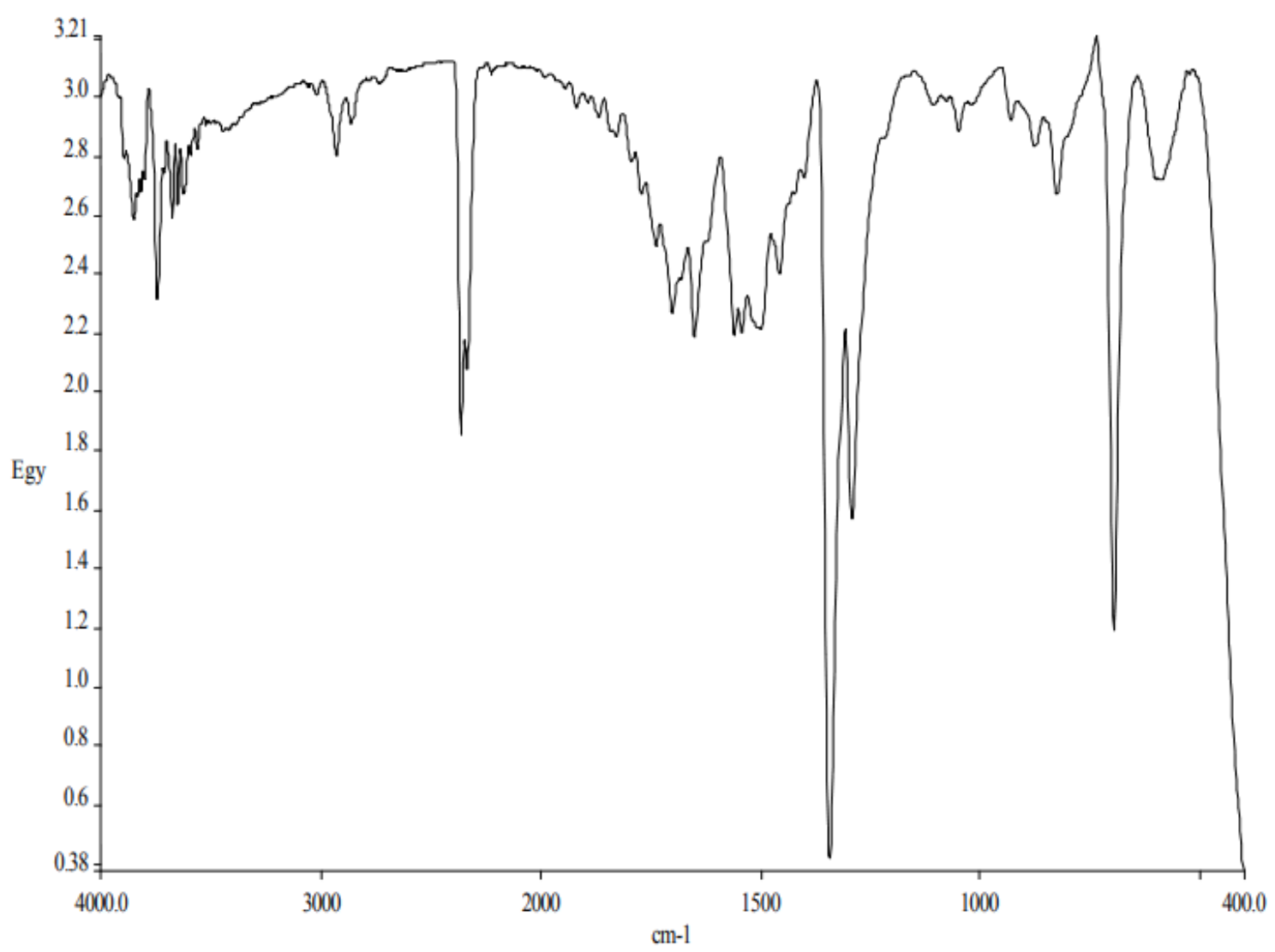

Figure A-1. Infrared Absorption Spectrum of Hexachlorobenzene

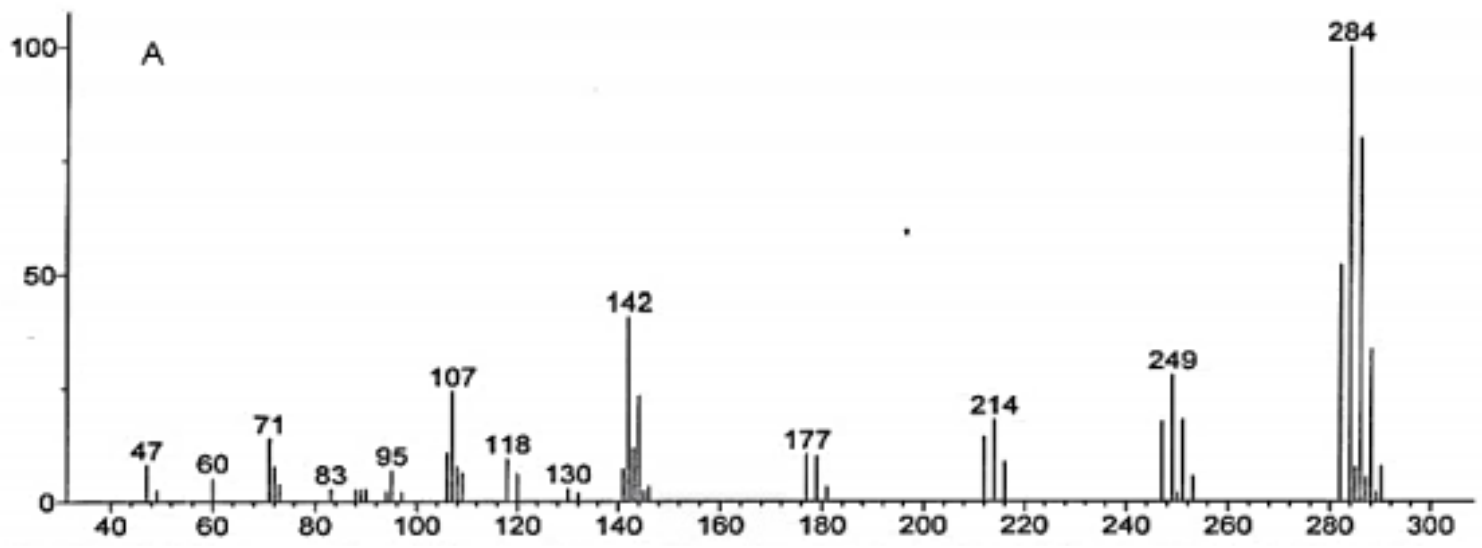

Figure A-2. Mass Spectrum of Hexachlorobenzene 


\section{Appendix B. Ingredients, Nutrient Composition, and Contaminant Levels in NTP-2000 Rat Ration}

\section{Tables}

Table B-1. Ingredients of NTP-2000 Rat Ration

Table B-2. Vitamins and Minerals in NTP-2000 Rat Ration...................................................

Table B-3. Nutrient Composition of NTP-2000 Rat Ration ......................................................

Table B-4. Contaminant Levels in NTP-2000 Rat Ration 
Table B-1. Ingredients of NTP-2000 Rat Ration

\begin{tabular}{|c|c|c|}
\hline Ingredients & & Percent by Weight \\
\hline Ground Hard Winter Wheat & & 22.26 \\
\hline Ground \#2 Yellow Shelled Corn & & 22.18 \\
\hline Wheat Middlings & & 15.0 \\
\hline Oat Hulls & & 8.5 \\
\hline Alfalfa Meal (Dehydrated, 17\% Protein) & & 7.5 \\
\hline Purified Cellulose & & 5.5 \\
\hline Soybean Meal (49\% Protein) & & 5.0 \\
\hline Fish Meal (60\% Protein) & & 4.0 \\
\hline Corn Oil (without Preservatives) & & 3.0 \\
\hline Soy Oil (without Preservatives) & & 3.0 \\
\hline Dried Brewer's Yeast & & 1.0 \\
\hline Calcium Carbonate (USP) & & 0.9 \\
\hline Vitamin Premix ${ }^{a}$ & & 0.5 \\
\hline Mineral Premix ${ }^{b}$ & & 0.5 \\
\hline Calcium Phosphate, Dibasic (USP) & & 0.4 \\
\hline Sodium Chloride & & 0.3 \\
\hline Choline Chloride ( $70 \%$ Choline) & & 0.26 \\
\hline Methionine & & 0.2 \\
\hline \multicolumn{3}{|l|}{$\begin{array}{l}\text { USP }=\text { United States Pharmacopeia. } \\
\text { aWheat middlings as carrier. } \\
\text { bCalcium carbonate as carrier. }\end{array}$} \\
\hline & Amount $^{\mathbf{a}}$ & Source \\
\hline \multicolumn{3}{|l|}{ Vitamins } \\
\hline Vitamin A & $4,000 \mathrm{IU}$ & Stabilized vitamin A palmitate or acetate \\
\hline Vitamin D & $1,000 \mathrm{IU}$ & D-activated animal sterol \\
\hline Vitamin K & $1.0 \mathrm{mg}$ & Menadione sodium bisulfite complex \\
\hline$\alpha$-Tocopheryl Acetate & $100 \mathrm{IU}$ & - \\
\hline Niacin & $23 \mathrm{mg}$ & - \\
\hline Folic Acid & $1.1 \mathrm{mg}$ & - \\
\hline d-Pantothenic Acid & $10 \mathrm{mg}$ & d-Calcium pantothenate \\
\hline Riboflavin & $3.3 \mathrm{mg}$ & - \\
\hline Thiamine & $4 \mathrm{mg}$ & Thiamine mononitrate \\
\hline Vitamin $B_{12}$ & $52 \mu \mathrm{g}$ & - \\
\hline Pyridoxine & $6.3 \mathrm{mg}$ & Pyridoxine hydrochloride \\
\hline
\end{tabular}


Hexachlorobenzene, NTP TOX 77

\begin{tabular}{lcl}
\hline & Amount $^{\mathbf{a}}$ & \multicolumn{1}{c}{ Source } \\
\hline Biotin & $0.2 \mathrm{mg}$ & d-Biotin \\
Minerals & & \\
Magnesium & $514 \mathrm{mg}$ & Magnesium oxide \\
Iron & $35 \mathrm{mg}$ & Iron sulfate \\
Zinc & $12 \mathrm{mg}$ & Zinc oxide \\
Manganese & $10 \mathrm{mg}$ & Manganese oxide \\
Copper & $2.0 \mathrm{mg}$ & Copper sulfate \\
Iodine & $0.2 \mathrm{mg}$ & Calcium iodate \\
Chromium & $0.2 \mathrm{mg}$ & Chromium acetate
\end{tabular}

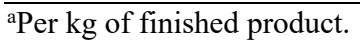

Table B-3. Nutrient Composition of NTP-2000 Rat Ration

\begin{tabular}{lccc}
\hline \multicolumn{1}{c}{ Nutrient } & $\begin{array}{c}\text { Mean } \pm \text { Standard } \\
\text { Deviation }\end{array}$ & Range & Number of Samples \\
\hline Protein (\% by weight) & $14.2 \pm 0.00$ & $14.2-14.2$ & 1 \\
Crude Fat (\% by weight) & $8.5 \pm 0.00$ & $8.5-8.5$ & 1 \\
Crude Fiber (\% by weight) & $8.8 \pm 0.00$ & $8.8-8.8$ & 1 \\
Ash (\% by weight) & $5.1 \pm 0.00$ & $5.1-5.1$ & 1 \\
Amino Acids (\% of Total Diet) & & & 22 \\
Arginine & $0.783 \pm 0.070$ & $0.670-0.970$ & 22 \\
Cystine & $0.220 \pm 0.024$ & $0.150-0.250$ & 22 \\
Glycine & $0.701 \pm 0.041$ & $0.620-0.800$ & 22 \\
Histidine & $0.352 \pm 0.077$ & $0.270-0.680$ & 22 \\
Isoleucine & $0.546 \pm 0.044$ & $0.430-0.660$ & 22 \\
Leucine & $1.095 \pm 0.067$ & $0.960-1.240$ & 22 \\
Lysine & $0.711 \pm 0.114$ & $0.310-0.860$ & 22 \\
Methionine & $0.409 \pm 0.046$ & $0.260-0.490$ & 22 \\
Phenylalanine & $0.628 \pm 0.040$ & $0.540-0.720$ & 22 \\
Threonine & $0.505 \pm 0.043$ & $0.430-0.610$ & 22 \\
Tryptophan & $0.150 \pm 0.028$ & $0.110-0.200$ & 22 \\
Tyrosine & $0.401 \pm 0.061$ & $0.280-0.540$ & \\
Valine & $0.665 \pm 0.043$ & $0.550-0.730$ & \\
Essential Fatty Acids (\% of Total Diet) & $3.49-4.55$ & $0.21-0.35$ \\
Linoleic & $3.95 \pm 0.259$ & & 22 \\
Linolenic & $0.30 \pm 0.032$ & & 22 \\
\hline
\end{tabular}


Hexachlorobenzene, NTP TOX 77

\begin{tabular}{|c|c|c|c|}
\hline Nutrient & $\begin{array}{c}\text { Mean } \pm \text { Standard } \\
\text { Deviation }\end{array}$ & Range & Number of Samples \\
\hline \multicolumn{4}{|l|}{ Vitamins } \\
\hline Vitamin A (IU/kg) & $5,870 \pm 0.00$ & $5,870-5,870$ & 1 \\
\hline Vitamin D (IU/kg) & $1,000^{\mathrm{a}}$ & - & - \\
\hline$\alpha$-Tocopherol (ppm) & $80.6 \pm 22.03$ & $27.0-124.0$ & 22 \\
\hline Thiamine (ppm) ${ }^{\mathrm{b}}$ & $7.3 \pm 0.00$ & $7.3-7.3$ & 1 \\
\hline Riboflavin (ppm) & $7.6 \pm 2.89$ & $4.20-17.50$ & 22 \\
\hline Niacin (ppm) & $78.9 \pm 9.08$ & $66.4-98.2$ & 22 \\
\hline Pantothenic Acid (ppm) & $26.9 \pm 12.63$ & $17.4-81.0$ & 22 \\
\hline Pyridoxine $(\mathrm{ppm})^{\mathrm{b}}$ & $9.54 \pm 1.99$ & $6.44-13.7$ & 22 \\
\hline Folic Acid (ppm) & $1.62 \pm 0.48$ & $1.15-3.27$ & 22 \\
\hline Biotin (ppm) & $0.32 \pm 0.10$ & $0.20-0.704$ & 22 \\
\hline Vitamin $B_{12}(\mathrm{ppb})$ & $53.6 \pm 39.6$ & $18.3-174.0$ & 22 \\
\hline $\begin{array}{l}\text { Choline (as Chloride) } \\
\text { (ppm) }\end{array}$ & $2,846 \pm 485$ & $1,820-3,790$ & 22 \\
\hline \multicolumn{4}{|l|}{ Minerals } \\
\hline Calcium (\%) & $1.140 \pm 0.000$ & $1.140-1.140$ & 1 \\
\hline Phosphorus (\%) & $0.632 \pm 0.000$ & $0.632-0.632$ & 1 \\
\hline Potassium (\%) & $0.666 \pm 0.030$ & $0.626-0.733$ & 22 \\
\hline Chloride (\%) & $0.386 \pm 0.039$ & $0.300-0.474$ & 22 \\
\hline Sodium (\%) & $0.189 \pm 0.016$ & $0.160-0.222$ & 22 \\
\hline Magnesium (\%) & $0.216 \pm 0.062$ & $0.185-0.490$ & 22 \\
\hline Sulfur (\%) & $0.170 \pm 0.029$ & $0.116-0.209$ & 14 \\
\hline Iron (ppm) & $186 \pm 39.2$ & $135-311$ & 22 \\
\hline Manganese (ppm) & $51.4 \pm 10.28$ & $21.0-73.1$ & 22 \\
\hline Zinc (ppm) & $53.4 \pm 8.46$ & $43.3-78.5$ & 22 \\
\hline Copper (ppm) & $7.01 \pm 2.562$ & $3.21-16.3$ & 22 \\
\hline Iodine (ppm) & $0.503 \pm 0.206$ & $0.158-0.972$ & 22 \\
\hline Chromium (ppm) & $0.694 \pm 0.276$ & $0.330-1.380$ & 22 \\
\hline Cobalt (ppm) & $0.256 \pm 0.164$ & $0.098-0.864$ & 22 \\
\hline
\end{tabular}

${ }^{\mathrm{a} F r o m}$ formulation.

${ }^{\mathrm{b}}$ As hydrochloride. 
Table B-4. Contaminant Levels in NTP-2000 Rat Ration

\begin{tabular}{|c|c|c|c|}
\hline & $\begin{array}{c}\text { Mean } \pm \text { Standard } \\
\text { Deviation }\end{array}$ & Range & Number of Samples \\
\hline \multicolumn{4}{|l|}{ Contaminants } \\
\hline Arsenic (ppm) & $0.17 \pm 0.00$ & $0.17-0.17$ & 1 \\
\hline Cadmium (ppm) & $0.04 \pm 0.00$ & $0.04-0.04$ & 1 \\
\hline Lead (ppm) & $0.07 \pm 0.00$ & $0.07-0.07$ & 1 \\
\hline Mercury $(\mathrm{ppm})^{\mathrm{a}}$ & $<0.02$ & - & 1 \\
\hline Selenium (ppm) & $0.25 \pm 0.00$ & $0.25-0.25$ & 1 \\
\hline Aflatoxins $(\mathrm{ppb})^{\mathrm{a}}$ & $<5.00$ & - & 1 \\
\hline Nitrate Nitrogen $(\mathrm{ppm})^{\mathrm{b}}$ & $6.85 \pm 0.00$ & $6.85-6.85$ & 1 \\
\hline Nitrite Nitrogen (ppm) $)^{\mathrm{a}, \mathrm{b}}$ & $<0.61$ & - & 1 \\
\hline BHA (ppm) $)^{\mathrm{a}, \mathrm{c}}$ & $<1.0$ & - & 1 \\
\hline BHT (ppm) $)^{\mathrm{a}, \mathrm{c}}$ & $<1.0$ & - & 1 \\
\hline Aerobic Plate Count (CFU/gm) & $10 \pm 0$ & $10-10$ & 1 \\
\hline Coliform (MPN/gm) & $3.6 \pm 0$ & $3.6-3.6$ & 1 \\
\hline Escherichia coli (MPN/gm) ${ }^{\mathrm{a}}$ & $<10$ & - & 1 \\
\hline Salmonella (MPN/gm) & Negative & - & 1 \\
\hline Total Nitrosamines (ppb) ${ }^{\mathrm{d}}$ & $5.9 \pm 0.00$ & $5.9-5.9$ & 1 \\
\hline N-Ndimethylamine $(\mathrm{ppb})^{\mathrm{d}}$ & $2.9 \pm 0.00$ & $2.9-2.9$ & 1 \\
\hline N-Npyrrolidine (ppb) ${ }^{\mathrm{d}}$ & $3.0 \pm 0.00$ & $3.0-3.0$ & 1 \\
\hline \multicolumn{4}{|l|}{ Pesticides (ppm) } \\
\hline$\alpha-\mathrm{BHC}^{\mathrm{a}}$ & $<0.01$ & - & 1 \\
\hline$\beta-\mathrm{BHC}^{\mathrm{a}}$ & $<0.02$ & - & 1 \\
\hline$\gamma-\mathrm{BHC}^{\mathrm{a}}$ & $<0.01$ & - & 1 \\
\hline$\delta-\mathrm{BHC}^{\mathrm{a}}$ & $<0.01$ & - & 1 \\
\hline Heptachlor $^{\mathrm{a}}$ & $<0.01$ & - & 1 \\
\hline Aldrin $^{\mathrm{a}}$ & $<0.01$ & - & 1 \\
\hline Heptachlor Epoxide ${ }^{\mathrm{a}}$ & $<0.01$ & - & 1 \\
\hline $\mathrm{DDE}^{\mathrm{a}}$ & $<0.01$ & - & 1 \\
\hline $\mathrm{DDD}^{\mathrm{a}}$ & $<0.01$ & - & 1 \\
\hline $\mathrm{DDT}^{\mathrm{a}}$ & $<0.01$ & - & 1 \\
\hline $\mathrm{HCB}^{\mathrm{a}}$ & $<0.01$ & - & 1 \\
\hline Mirex $^{\mathrm{a}}$ & $<0.01$ & - & 1 \\
\hline Methoxychlor ${ }^{\mathrm{a}}$ & $<0.05$ & - & 1 \\
\hline Dieldrin $^{\mathrm{a}}$ & $<0.01$ & - & 1 \\
\hline Endrin $^{\mathrm{a}}$ & $<0.01$ & - & 1 \\
\hline
\end{tabular}


Hexachlorobenzene, NTP TOX 77

\begin{tabular}{lccc}
\hline & $\begin{array}{c}\text { Mean } \\
\text { Deviation }\end{array}$ & Range & Number of Samples \\
\hline Telodrin $^{\mathrm{a}}$ & $<0.01$ & - & 1 \\
Chlordane $^{\mathrm{a}}$ & $<0.05$ & - & 1 \\
Toxaphene $^{\mathrm{a}}$ & $<0.10$ & - & 1 \\
Estimated PCBs $^{\mathrm{a}}$ & $<0.20$ & - & 1 \\
Ronnel $^{\mathrm{a}}$ & $<0.01$ & - & 1 \\
Ethion $^{\mathrm{a}}$ & $<0.02$ & - & 1 \\
Trithion $^{\mathrm{a}}$ & $<0.05$ & - & 1 \\
Diazinon $^{\mathrm{a}}$ & $<0.10$ & - & 1 \\
Methyl Chlorpyrifos & $0.199 \pm 0.00$ & - & 1 \\
Methyl Parathion $^{\mathrm{a}}$ & $<0.02$ & $-199-0.199$ & 1 \\
Ethyl Parathion $^{\mathrm{a}}$ & $<0.02$ & - & 1 \\
Malathion $^{\text {Endosulfan I }}$ & $0.56 \pm 0.00$ & - & 1 \\
Endosulfan II $^{\mathrm{a}}$ & $<0.01$ & - & 1 \\
Endosulfane Sulfate $^{\mathrm{a}}$ & $<0.01$ & -0.03 &
\end{tabular}

All samples were irradiated.

$\mathrm{BHA}=$ butylated hydroxyanisole; $\mathrm{BHT}=$ butylated hydroxytoluene; $\mathrm{CFU}=$ colony-forming units; $\mathrm{MPN}=$ most probable

number; $\mathrm{BHC}=$ hexachlorocyclohexane or benzene hexachloride; DDE = dichlorodiphenyldichloroethylene;

$\mathrm{DDD}=$ dichlorodiphenyldichloroethane; DDT = dichlorodiphenyltrichloroethane; $\mathrm{HCB}=$ hexachlorobenzene;

$\mathrm{PCB}=$ polychlorinated biphenyl.

${ }^{a}$ All values were below the detection limit. The detection limit is given as the mean.

bources of contamination include alfalfa, grains, and fish meal.

${ }^{\mathrm{c} S}$ Sources of contamination include soy oil and fish meal.

${ }^{\mathrm{d} A l l}$ values were corrected for percent recovery. 
Hexachlorobenzene, NTP TOX 77

\section{Appendix C. Sentinel Animal Program \\ Table of Contents}

C.1. Methods

C-2

C.2. Results

C-2

Tables

Table C-1. Methods and Results for Sentinel Animal Testing in Female Rats in the

Three-month Study... 


\section{C.1. Methods}

Rodents used in the National Toxicology Program are produced in optimally clean facilities to eliminate potential pathogens that could affect study results. The Sentinel Animal Program is part of the periodic monitoring of animal health that occurs during the toxicological evaluation of test compounds. Under this program, the disease state of the rodents is monitored via sera from extra (sentinel) or exposed animals in the study rooms. The sentinel animals and the study animals are subject to identical environmental conditions. Furthermore, the sentinel animals come from the same production source and weanling groups as the animals used for the studies of test compounds.

In the 3-month studies, blood samples were collected from each sentinel animal, allowed to clot, and the serum was separated. The serum samples were processed appropriately and sent to BioReliance Corporation (Rockville, MD) for determination of the presence of pathogens. The laboratory methods and agents for which testing was performed are tabulated below; the times at which samples were collected during the studies are also listed.

Blood was collected from 10 female rats during the quarantine period and at 4 weeks after the start of dosing; blood was collected from 9 female rats at study termination.

Table C-1. Methods and Results for Sentinel Animal Testing in Female Rats in the Three-month Study

Method and Test Time of Collection

\section{ELISA}

Mycoplasma arthritidis

Mycoplasma pulmonis

Pneumonia Virus of Mice

Rat Coronavirus/Sialodacryoadenitis Virus

Sendai

Immunofluorescence Assay

Mycoplasma arthritidis

Parvovirus

ELISA = enzyme-linked immunosorbent assay.

\section{C.2. Results}

All test results were negative.
Study termination

Study termination

End of quarantine; 4 weeks; study termination

End of quarantine; 4 weeks; study termination

End of quarantine; 4 weeks; study termination

Study termination

End of quarantine; 4 weeks; study termination 


\section{Appendix D. Toxicokinetic Data}

\section{Table of Contents}

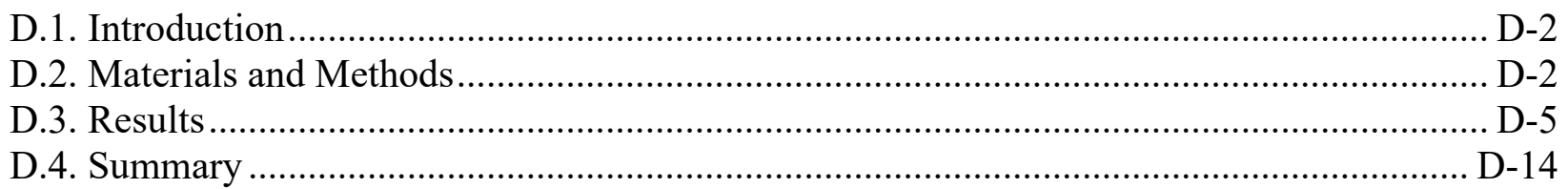

\section{Tables}

Table D-1. Study Design for the Oral and Intravenous Toxicokinetic Studies in Female

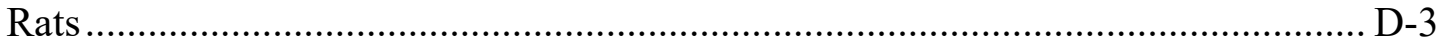

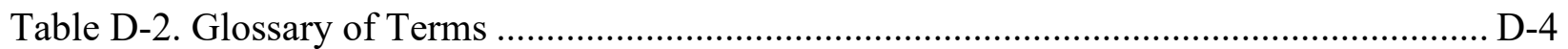

Table D-3. Analytical Method Validation for Hexachlorobenzene in Blood........................... D-5

Table D-4. Analytical Method Validation for Hexachlorobenzene in Adipose ........................ D-6

Table D-5. Analytical Method Validation for Hexachlorobenzene in Liver .......................... D-6

Table D-6. Analytical Method Validation for Hexachlorobenzene in Lung ........................... D-7

Table D-7. Plasma Toxicokinetic Parameters of Hexachlorobenzene Following Single Intravenous Administration in Female Rats .................................................... D-8

Table D-8. Plasma Toxicokinetic Parameters of Hexachlorobenzene Following Single Gavage Administration in Female Rats................................................................ D-9

Table D-9. Bioavailability of Hexachlorobenzene Following Single Gavage Administration in Female Rats .................................................................. D-10

Table D-10. Toxicokinetic Parameters of Hexachlorobenzene in Tissues Following Single Administration in Female Rats ........................................................ D-13

Table D-11. Ratio of Tissue and Blood Mean Area under the Curve..................................... D-14

\section{Figures}

Figure D-1. Blood Concentrations versus Time Profiles of Hexachlorobenzene after a Single Intravenous Administration of a 100 (A) or 1,000 (B) $\mu \mathrm{g} / \mathrm{kg}$ Dose in

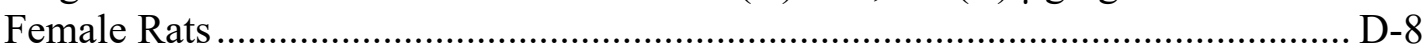

Figure D-2. Blood Concentrations versus Time Profiles of Hexachlorobenzene after a Single Gavage Administration of a 30 (A), 300 (B), or 30,000 (C) $\mu \mathrm{g} / \mathrm{kg}$ Dose in Female Rats.

Figure D-3. Concentrations of Hexachlorobenzene Over Time in Adipose Tissue (A-B), Liver $(\mathrm{C}-\mathrm{D})$, and Lung $(\mathrm{E}-\mathrm{F})$ after a Single Intravenous Administration of a 100 or $1,000 \mu \mathrm{g} / \mathrm{kg}$ Dose in Female Rats

Figure D-4. Concentrations of Hexachlorobenzene Over Time in Adipose Tissue (A-C), Liver (D-F), and Lung (G-I) after a Single Gavage Administration of a 30, 300 , or $30,000 \mu \mathrm{g} / \mathrm{kg}$ Dose in Female Rats 


\section{D.1. Introduction}

Due to the paucity of toxicity data, the National Toxicology Program evaluated the toxicity of hexachlorobenzene (HCB). To support the toxicity studies, toxicokinetic evaluations were conducted in female Sprague Dawley (Hsd:Sprague Dawley ${ }^{\circledR} \mathrm{SD}^{\circledR}$ ) rats administered a single dose of HCB by oral gavage (30,300, and $30,000 \mu \mathrm{g} / \mathrm{kg}$ ) or intravenously (IV; 100 and $1,000 \mu \mathrm{g} / \mathrm{kg})$.

\section{D.2. Materials and Methods}

\section{D.2.1. Chemicals and Dose Formulation}

HCB was obtained from Aldrich Chemical Company, Milwaukee, WI (Lot No. 08526EF). The chemical identity was confirmed using infrared spectroscopy, ${ }^{13} \mathrm{C}$ NMR, and gas chromatography/mass spectrometry (GC/MS). The purity was determined to be $>99 \%$ by GC with flame ionization detection. Corn oil, the oral dose vehicle, was obtained from Spectrum Quality Products, Inc. (Gardena, CA; Lot No. NL0405 or OJ0240). The IV dose formulation vehicle was a homogenous solution (5:0.15:0.14:95 v/w/w/v) of corn oil, cholic acid (Lot No. 128H0154; Sigma, St. Louis, MO), lecithin (Lot No. 49H8018; Sigma, St. Louis, MO), and Ringer's solution (Lot No. C437210; Baxter, Deerfield, IL).

Oral dose formulations of $\mathrm{HCB}(12 \mu \mathrm{g} \mathrm{HCB} / \mathrm{mL}, 120 \mu \mathrm{g} \mathrm{HCB} / \mathrm{mL}$, and $12 \mathrm{mg} \mathrm{HCB} / \mathrm{mL})$ were prepared in corn oil. IV dose formulations ( 25 and $250 \mu \mathrm{g} / \mathrm{mL}$ ) were prepared in the IV formulation vehicle. Formulations were analyzed by a validated GC method using a HewlettPackard Model 6890 with electron capture detection (ECD) (linear range 50 to $497 \mathrm{ng} / \mathrm{mL}$; $\mathrm{r} \geq 0.99$; accuracy: $\leq 4.4 \%$, estimated as relative error; precision: $\leq 0.7 \%$, estimated as relative standard deviation. All oral and IV formulations were within $10 \%$ of the target concentration. Prior to study initiation, stability ( $\leq 10 \%$ of day 0 ) of both oral and IV formulations were confirmed for up to 35 days when stored at ambient or refrigerated conditions.

\section{D.2.2. Animals}

Two studies (one evaluating 30 and 3,000 $\mu \mathrm{g} / \mathrm{kg}$ gavage doses, another evaluating IV doses and $300 \mu \mathrm{g} / \mathrm{kg}$ gavage dose) were conducted at MRIGlobal (Kansas City, MO) in accordance with the guidelines of the U.S. Department of Agriculture through the Animal Welfare Act (Public Law 89-544 and its subsequent amendments), Guide for the Care and Use of Laboratory Animals, DHHS Publication No. (NIH) 86-23 (Revised, 1985) and MRIGlobal Standard Operating Procedure. Animals were housed in facilities that are fully accredited by AAALAC International. Nine-week-old female Sprague Dawley rats were received from Charles River (Portage, MI) and randomized into dose groups. Rats were housed in environmentally controlled rooms, with at least 10 room air exchanges per hour, a 12-hour light/dark cycle per day, room temperature of $66^{\circ} \mathrm{F}-83^{\circ} \mathrm{F}$, and relative humidity from $28 \%$ to $77 \%$. Animals had access to NTP2000 meal feed (Ziegler Brothers, Inc., Gardeners, PA) and water from the public water supply ad libitum.

Body weights were recorded for all animals prior to the start of the study, on the day of dosing prior to dose administration, and prior to euthanasia. Single IV doses were administered at 100 and $1,000 \mu \mathrm{g} / \mathrm{kg}$ in a volume of $4.0 \mathrm{~mL} / \mathrm{kg}$ via the lateral tail vein. Oral doses were administered 
at 30,300 , and $30,000 \mu \mathrm{g} / \mathrm{kg}$ in $2.5 \mathrm{~mL} / \mathrm{kg}$ via oral gavage. Animals were 21 weeks of age at time of dosing.

\section{D.2.3. Sample Collection and Analysis}

Following dose administration, whole blood samples were collected into heparinized tubes at 5-6 time points. Table D-1 shows the study design and time points for blood and tissue collections. Non-terminal blood collections $(\mathrm{n}=10$ /time point, $2 \mathrm{~mL})$ were collected via the retroorbital sinus under light $\mathrm{CO}_{2}$ anesthesia. For tissue collection time points, animals ( $\mathrm{n}=5 /$ time point) were euthanized by exsanguination via the abdominal aorta under Metofane (Mallinckrodt Veterinary, Mundelein, IL) anesthesia; whole blood, liver, lung, and mesenteric adipose were collected. Organs were weighed at the time of collection. All samples were stored at $-20^{\circ} \mathrm{C}$ until analysis.

Table D-1. Study Design for the Oral and Intravenous Toxicokinetic Studies in Female Rats

\begin{tabular}{|c|c|c|c|}
\hline Study & $\begin{array}{l}\text { Route of } \\
\text { Administration and Dose }\end{array}$ & $\begin{array}{l}\text { Blood Collection } \\
\text { Time Points }\end{array}$ & $\begin{array}{l}\text { Tissue Collection } \\
\text { Time Points }\end{array}$ \\
\hline 1 & Gavage: 30 and $30,000 \mu \mathrm{g} / \mathrm{kg}$ & $0.5,1,12,120,240$ & $\begin{array}{l}72,168,336,672,1,008,1,344,1,680 \\
2,016(3,7,14,28,42,56,70,84)\end{array}$ \\
\hline \multirow[t]{2}{*}{2} & IV:100 and $1,000 \mu \mathrm{g} / \mathrm{kg}$ & $0.25,0.5,1,12,120,240$ & $\begin{array}{l}48,72,168,336,672,1,008,1,344,1,680, \\
2,016(2,3,7,14,28,42,56,70,84)\end{array}$ \\
\hline & Gavage: $300 \mu \mathrm{g} / \mathrm{kg}$ & $0.5,1,12,120,240$ & $\begin{array}{l}72,168,336,672,1,008,1,344,1,680 \\
2,016(3,7,14,28,42,56,70,84)\end{array}$ \\
\hline
\end{tabular}

IV = intravenous.

${ }^{\mathrm{a}} \mathrm{n}=10$; data are presented in hours.

$\mathrm{b}_{\mathrm{n}}=5$; data are presented in hours (days).

All samples were analyzed using validated analytical methods (Table D-3, Table D-4, Table D-5, Table D-6). $100 \mu \mathrm{L}$ of acetonitrile was added to $100 \mu \mathrm{L}$ aliquots of blood in individual vials. Samples were mixed for approximately 20 seconds, followed by the addition of $100 \mu \mathrm{L}$ of the internal standard solution (isodrin, approximately $2 \mu \mathrm{g} / \mathrm{mL}$ in hexane) and $900 \mu \mathrm{L}$ of hexane. The contents of each vial were mixed for approximately 40 seconds. Vials were centrifuged at approximately $800 \mathrm{~g}$ for approximately 5 minutes and the supernatant was collected for analysis. Liver and lung samples (0.1-0.4 g of tissue) were prepared similarly to blood except that tissues were homogenized using Polytron homogenizer prior to protein precipitation with approximately $0.5 \mathrm{~mL}$ acetonitrile. Adipose tissue samples were prepared by homogenizing $0.1-0.4 \mathrm{~g}$ of adipose tissue and then adding $1 \mathrm{~mL}$ hexane. The homogenized adipose sample was transferred to an individual solid phase extraction cartridge and eluted with approximately $20 \mathrm{~mL}$ hexane. The hexane eluate was collected and diluted to $25 \mathrm{~mL}$ with hexane, and $1 \mathrm{~mL}$ was combined with $0.5 \mathrm{~mL}$ internal standard solution (approximately $0.1-1 \mu \mathrm{g} / \mathrm{mL}$ aldrin in hexane) for analysis. High-dose samples were diluted with control matrix into the analytical method range (20-5,000 ng/mL) prior to extraction when necessary. Standard curves and blanks were prepared with each sample set.

Blood, adipose, and lung samples, standards, and blanks were analyzed using a HewlettPackard/Agilent $6890 \mathrm{GC}$ with an ECD detector. Analyte separation was achieved on a Restek RTX-5 column $(60 \mathrm{~m}, 0.25 \mathrm{~mm}$ internal diameter [I.D.], $0.25 \mu \mathrm{M}$ film thickness or $30 \mathrm{~m}$, $0.53 \mathrm{~mm}$ I.D, $0.15 \mu \mathrm{m}$ film thickness). For analysis of samples, the oven temperature program 
was $100^{\circ} \mathrm{C}$ (2-minute hold), then $50^{\circ} \mathrm{C} /$ minute to $200^{\circ} \mathrm{C}$ (1-minute hold), then $4^{\circ} \mathrm{C} /$ minute to $300^{\circ} \mathrm{C}$. For analysis of adipose in the high-dose samples, the oven temperature program was $180^{\circ} \mathrm{C}$ (5-minute hold), then ramped at $5^{\circ} \mathrm{C} /$ minute to $275^{\circ} \mathrm{C}$ (5-minute hold). Liver, lung, and blood samples, standards, and blanks were analyzed using a Fisons 8030 GC with MD800-F MS detector with a J \& W DB-5 column (30 m, $0.32 \mathrm{~mm}$ I.D., $1 \mu \mathrm{m}$ film thickness) and an oven program of $70^{\circ} \mathrm{C}$ (2-minute hold), ramped at $50^{\circ} \mathrm{C} /$ minute to $200^{\circ} \mathrm{C}$ (1-minute hold), then $4^{\circ} \mathrm{C} /$ minute to $300^{\circ} \mathrm{C}$.

\section{D.2.4. Toxicokinetic Analysis}

WinNonlin (Version 8, Certara, Princeton, NJ) was used for toxicokinetic analysis. Blood HCB concentration versus time profiles utilizing all data points ( 5 or 10 rats per time point) were analyzed using various compartmental models. For each compartmental model, data sets were analyzed with and without weighting. The model and the weighing factor that resulted in the best goodness of fit was selected as the final model. On this basis, a two-compartment model with bolus input, first order output, and $1 / \mathrm{y}^{2}$ weighting was used for the IV data (equation 1 ), and a two-compartment model with first order input, first order output, and $1 / \mathrm{y}^{2}$ weighting was used for gavage data (equation 2). The kinetic parameters estimated are listed and defined in Table D-2. Tissue concentration versus time data were evaluated using noncompartmental analysis (NCA) with each data point representing the mean of five rats per dose group. Only data that were at or above the limit of detection were used in the calculations.
$\mathrm{C}_{(\mathrm{t})}=\mathrm{Ae}^{-\alpha \mathrm{t}}+B \mathrm{Be}^{-\beta \mathrm{t}}$
[Equation 1]
$\mathrm{C}_{(\mathrm{t})}=\mathrm{Ae}^{-\alpha \mathrm{t}}+\mathrm{Be}^{-\beta \mathrm{t}}+\mathrm{Ce}^{-\mathrm{k}} 01^{\mathrm{t}}$
[Equation 2]

Bioavailability following gavage administration was estimated using equation 3 :

$\mathrm{F} \%=\left[\mathrm{AUC}_{(\text {gavage })} / \operatorname{Dose}_{(\text {gavage })}\right] /\left[\mathrm{AUC}_{(\mathrm{IV})} / \operatorname{Dose}_{(\mathrm{IV})}\right] \times 100 \quad$ [Equation 3]

Table D-2. Glossary of Terms

\begin{tabular}{ll}
\hline \multicolumn{1}{c}{ Alpha Half-life } & \multicolumn{1}{c}{ Half-life for the Alpha Phase } \\
\hline AUC & Area under the curve from the time of dosing extrapolated to infinity \\
AUC/Dose & Area under the curve adjusted for dose \\
Beta Half-life & Half-life for the beta phase \\
$\mathrm{C}_{0}$ & Concentration at time zero \\
$\mathrm{C}_{0} /$ Dose & Concentration at time zero adjusted for dose \\
$\mathrm{CL}_{1}$ and $\mathrm{CL}_{1} \mathrm{~F}$ & Clearance for the central compartment (IV and oral) \\
$\mathrm{CL}_{2}$ and $\mathrm{CL}_{2} \mathrm{~F}$ & Clearance for the peripheral compartment (IV and oral) \\
$\mathrm{C}_{\max }$ & Maximum concentration \\
$\mathrm{F}$ & Bioavailability \\
$\mathrm{K}_{10}$ & Elimination rate constant \\
$\mathrm{IK}_{10}$ Half-life & Half-life of elimination \\
$\mathrm{K}_{12}$ and $\mathrm{K}_{21}$ & Distribution rate constants \\
MRT & Mean residence time
\end{tabular}




\begin{tabular}{ll}
\hline \multicolumn{1}{c}{ Alpha Half-life } & \multicolumn{1}{c}{ Half-life for the Alpha Phase } \\
\hline $\mathrm{T}_{\max }$ & Time to reach maximum concentration \\
$\mathrm{V}_{1}$ and $\mathrm{V}_{1} \mathrm{~F}$ & Volume of distribution in the central compartment (IV and oral) \\
$\mathrm{V}_{2}$ and $\mathrm{V}_{2} \mathrm{~F}$ & Volume of distribution in the peripheral compartment (IV and oral) \\
$\mathrm{V}_{\mathrm{ss}}$ & Volume of distribution at steady state \\
\hline $\mathrm{IV}=$ intravenous. &
\end{tabular}

\section{D.3. Results}

No animals were found dead or moribund due to toxicity or any dose-related clinical signs observed following IV or gavage administration of HCB at any dose level.

\section{D.3.1. Analytical Method Validation}

Analytical methods for HCB were validated and analyte stability was evaluated in all matrices (Table D-3, Table D-4, Table D-5, Table D-6). The analytical method was suitable for quantitation of HCB in all matrices ( $r \geq 0.99$; precision $\leq 5.7 \%$; accuracy $\leq \pm 19.3 \%$ ). HCB was stable in all matrices at $-20^{\circ} \mathrm{C}$ for up to 21 days.

Table D-3. Analytical Method Validation for Hexachlorobenzene in Blood

\begin{tabular}{|c|c|c|}
\hline & \multicolumn{2}{|c|}{ Matrix Concentration Range (ng/mL) } \\
\hline & $1-400$ & $20-5,000$ \\
\hline Analytical Instrument & $\begin{array}{l}\text { Fisons } 8030 \text { GC with MD800-1 } \\
\text { MS detector }\end{array}$ & $\begin{array}{l}\text { Agilent } 6890 \mathrm{GC} \text { with EC } \\
\text { detector }\end{array}$ \\
\hline \multicolumn{3}{|l|}{ Validation Parameters } \\
\hline \multicolumn{3}{|l|}{ Limits (ng/mL or $\mathrm{ng} / \mathrm{g}$ ) } \\
\hline Limit of detection & 0.5 & 2.2 \\
\hline Experimental limit of quantitation & 4 & 20 \\
\hline Linearity $\left(\mathrm{R}^{2}\right)$ & $\geq 0.99$ & $\geq 0.99$ \\
\hline Accuracy (\% RE) & $\leq \pm 19.3$ & $\leq \pm 8.5$ \\
\hline Precision (\% RSD) & $\leq 5.7$ & $\leq 3.6$ \\
\hline Mean Recovery ${ }^{\mathrm{a}}(\%)$ & $\geq 57.3$ & $\geq 84.5$ \\
\hline \multicolumn{3}{|c|}{ Stability of Hexachlorobenzene at $20^{\circ} \mathrm{C}$ for up to 21 Days $^{\mathrm{b}}$} \\
\hline$\%$ of Target Concentration & \multicolumn{2}{|c|}{$\geq 91.7$} \\
\hline$\% \mathrm{RE}$ & \multicolumn{2}{|c|}{$\leq \pm 3.6$} \\
\hline
\end{tabular}


Table D-4. Analytical Method Validation for Hexachlorobenzene in Adipose

\begin{tabular}{|c|c|c|}
\hline & \multicolumn{2}{|c|}{ Matrix Concentration Range (ng/g) } \\
\hline & 50-385 & $350-2,300$ \\
\hline Analytical Instrument & \multicolumn{2}{|c|}{ Agilent $6890 \mathrm{GC}$ with EC detector Agilent $6890 \mathrm{GC}$ with EC detector } \\
\hline \multicolumn{3}{|l|}{ Validation Parameters } \\
\hline \multicolumn{3}{|l|}{ Limits $(\mathrm{ng} / \mathrm{mL}$ or $\mathrm{ng} / \mathrm{g})$} \\
\hline Limit of detection & 5.2 & 5.2 \\
\hline Experimental limit of quantitation & 50 & 50 \\
\hline Linearity $\left(\mathrm{R}^{2}\right)$ & $\geq 0.99$ & $\geq 0.99$ \\
\hline Accuracy $(\% \mathrm{RE})$ & $\leq \pm 9.1$ & $\leq \pm 8.7$ \\
\hline Precision (\% RSD) & $\leq 4.5$ & $\leq 4.5$ \\
\hline Recovery $^{\mathrm{a}}(\%)$ & $\geq 92.0$ & $\geq 93.1$ \\
\hline \multicolumn{3}{|c|}{ Stability of Hexachlorobenzene at $20^{\circ} \mathrm{C}$ for up to 21 Days $^{b}$} \\
\hline$\%$ of Target Concentration & \multicolumn{2}{|c|}{$\geq 90.9$} \\
\hline$\%$ RE & \multicolumn{2}{|c|}{$\leq \pm 8.4$} \\
\hline \multicolumn{3}{|c|}{$\begin{array}{l}\text { GC = gas chromatography; } \mathrm{EC}=\text { electron capture; } \mathrm{RE}=\text { relative error; } \mathrm{RSD}=\text { relative standard deviation. } \\
\text { aRelative to corresponding solvent standards. } \\
\text { bConcentration tested was } 191.1 \mu \mathrm{g} / \mathrm{g} .\end{array}$} \\
\hline \multicolumn{3}{|c|}{ Matrix Concentration Range (ng/g) } \\
\hline & \multicolumn{2}{|c|}{$1-10,000$} \\
\hline Analytical Instrument & \multicolumn{2}{|c|}{ Fisons 8030 GC with MD800-F MS detector } \\
\hline \multicolumn{3}{|l|}{ Validation Parameters } \\
\hline \multicolumn{3}{|l|}{ Limits (ng/mL or ng/g) } \\
\hline Limit of detection & \multicolumn{2}{|c|}{0.05} \\
\hline Experimental limit of quantitation & \multicolumn{2}{|c|}{1} \\
\hline Linearity $\left(\mathrm{R}^{2}\right)$ & \multicolumn{2}{|c|}{$\geq 0.99$} \\
\hline Accuracy $(\%$ RE $)$ & \multicolumn{2}{|c|}{$\leq \pm 11.4$} \\
\hline Precision (\% RSD) & \multicolumn{2}{|c|}{$\leq 5.4$} \\
\hline Recovery $^{\mathrm{a}}(\%)$ & \multicolumn{2}{|c|}{$\geq 81.4$} \\
\hline \multicolumn{3}{|c|}{ Stability of Hexachlorobenzene at $20^{\circ} \mathrm{C}$ for up to 21 Days $^{b}$} \\
\hline$\%$ of Target Concentration & & \\
\hline$\% \mathrm{RE}$ & & \\
\hline
\end{tabular}


Table D-6. Analytical Method Validation for Hexachlorobenzene in Lung

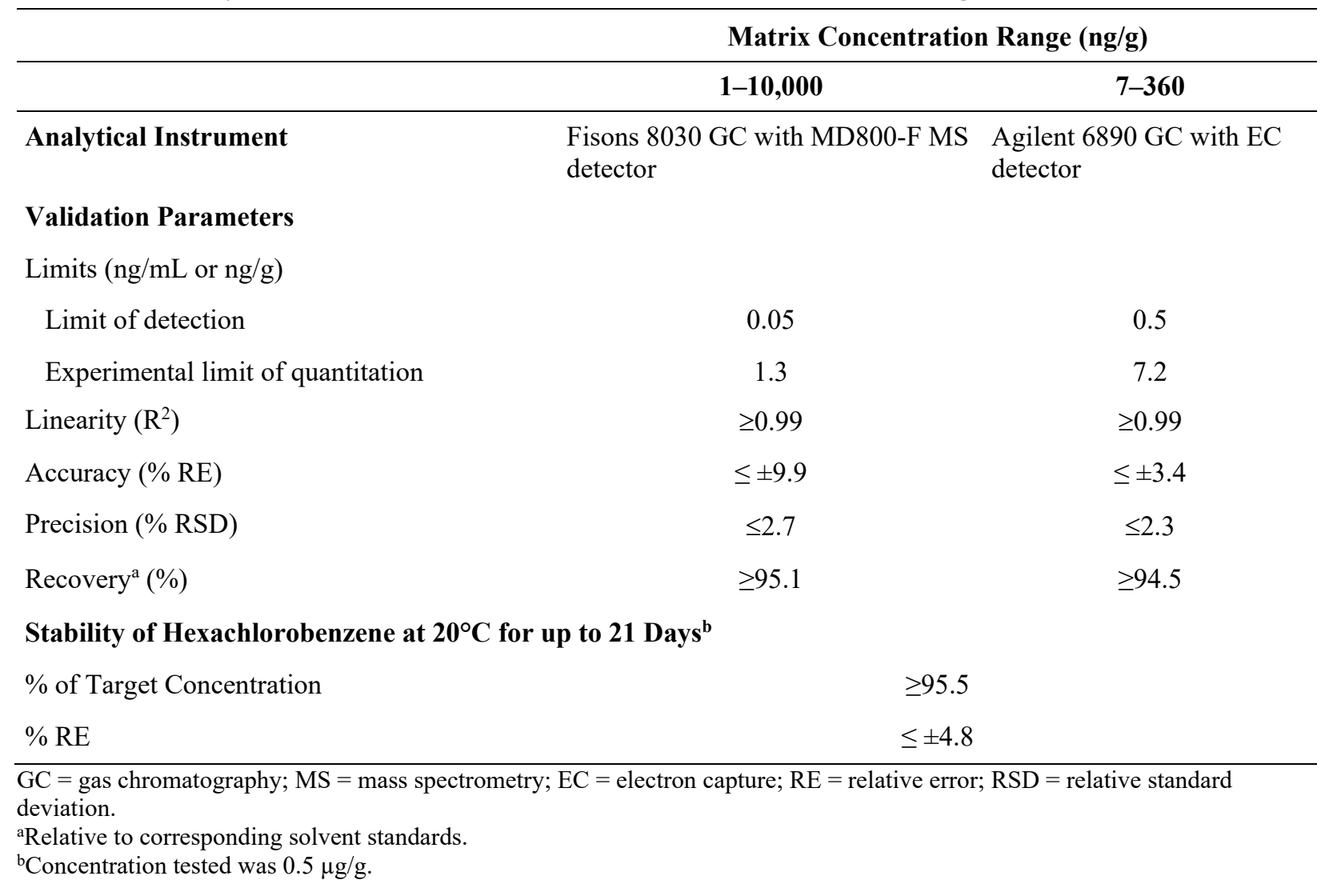

\section{D.3.2. Blood Toxicokinetics of Hexachlorobenzene}

HCB concentrations in blood were at or above the limit of detection at all time points for all doses. After IV and gavage administration, concentrations of HCB in the blood over time were best fit with a two-compartment model with first order absorption and/or elimination (Figure D-1 and Figure D-2). Following IV administration, the concentration at time $0\left(\mathrm{C}_{0}\right)$ and area under the curve (AUC) increased proportionally to the dose administered (Table D-7). The volume of distribution to the second compartment $\left(\mathrm{V}_{2} ; 12,700-12,900 \mathrm{~mL} / \mathrm{kg}\right)$ exceeded the estimated volume of aqueous body volume in rats $(668 \mathrm{~mL} / \mathrm{kg})$, suggesting distribution of HCB into tissues. The elimination half-life $\left(\mathrm{K}_{10}\right.$ half-life) in blood was similar for both doses $(70.5-$ 80.9 hours). 
Hexachlorobenzene, NTP TOX 77
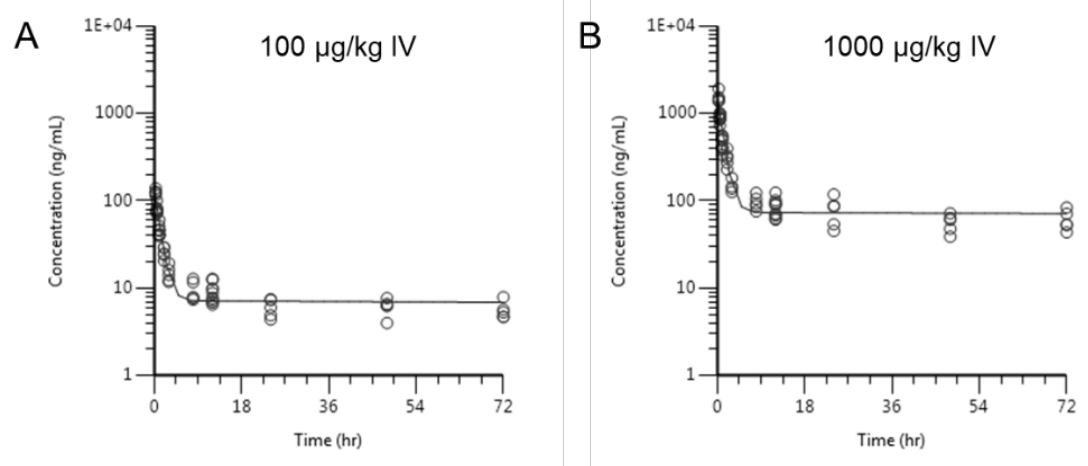

Figure D-1. Blood Concentrations versus Time Profiles of Hexachlorobenzene after a Single Intravenous Administration of a 100 (A) or 1,000 (B) $\mu \mathrm{g} / \mathrm{kg}$ Dose in Female Rats

A two-compartmental model with bolus input, first order output, and $1 / \mathrm{y}^{2}$ weighting was used to fit the data.

Table D-7. Plasma Toxicokinetic Parameters of Hexachlorobenzene Following Single Intravenous Administration in Female Rats ${ }^{\mathrm{a}}$

\begin{tabular}{lcc}
\hline & & \\
& Parameter $^{\mathbf{b}}$ & Dose \\
\cline { 2 - 3 } & $\mathbf{1 0 0} \boldsymbol{\mu \mathbf { g } / \mathbf { k g }}$ & $\mathbf{1 , 0 0 0} \boldsymbol{\mu g} / \mathbf{k g}$ \\
\hline $\mathrm{C}_{0}(\mathrm{ng} / \mathrm{mL})$ & $127(11)$ & $1,490(120)$ \\
$\mathrm{C}_{0} / \mathrm{Dose}(\mathrm{ng} / \mathrm{mL} / \mu \mathrm{g} / \mathrm{kg})$ & $1.27(0.11)$ & $1.49(0.12)$ \\
Alpha Half-life $(\mathrm{hr})$ & $0.783(0.065)$ & $0.724(0.058)$ \\
Beta Half-life $(\mathrm{hr})$ & $1,240(110)$ & $1,630(170)$ \\
$\mathrm{K}_{10}(1 / \mathrm{hr})$ & $0.0098(0.0011)$ & $0.0086(0.0010)$ \\
$\mathrm{K}_{10} \mathrm{Half}-\mathrm{life}(\mathrm{hr})$ & $70.5(8)$ & $80.9(9.7)$ \\
$\mathrm{K}_{12}$ & $0.876(0.081)$ & $0.902(0.075)$ \\
$\mathrm{K}_{21}$ & $0.0535(0.0039)$ & $0.0476(0.0031)$ \\
$\mathrm{CL}_{1}(\mathrm{~mL} / \mathrm{hr} / \mathrm{kg})$ & $7.71(0.54)$ & $5.74(0.5)$ \\
$\mathrm{CL}_{2}(\mathrm{~mL} / \mathrm{hr} / \mathrm{kg})$ & $687(39)$ & $604(31)$ \\
$\mathrm{V}_{1}(\mathrm{~mL} / \mathrm{kg})$ & $784(69)$ & $669(54)$ \\
$\mathrm{V}_{2}(\mathrm{~mL} / \mathrm{kg})$ & $12,900(500)$ & $12,700(500)$ \\
$\mathrm{V}_{\mathrm{ss}}(\mathrm{mL} / \mathrm{kg})$ & $13,600(500)$ & $13,300(500)$ \\
$\mathrm{MRT}(\mathrm{hr} * \mathrm{ng} / \mathrm{mL})$ & $1,770(160)$ & $2,330(250)$ \\
$\mathrm{AUC}(\mathrm{hr} * \mathrm{ng} / \mathrm{mL})$ & $13,000(900)$ & $174,000(15,000)$ \\
$\mathrm{AUC} / \mathrm{Dose}{ }^{\mathrm{c}}(\mathrm{hr} * \mathrm{ng} / \mathrm{mL} / \mu \mathrm{gg} / \mathrm{kg})$ & $130(9)$ & $174(15)$ \\
\hline
\end{tabular}

aased on a two-compartment model with first order elimination.

${ }^{b}$ Data are presented as mean (standard error).

cDose-adjusted area under the tissue concentration-time curve. 
Following gavage administration of $\mathrm{HCB}$, maximum concentration $\left(\mathrm{C}_{\max }\right)$ was reached within 34 hours for all doses and increased in a dose-proportional manner (Figure D-2, Table D-8). The blood elimination half-life ( $\mathrm{K}_{10}$ half-life) was 559 hours (approximately 23 days) at the $30 \mu \mathrm{g} / \mathrm{kg}$ dose administered but fell to 284-295 hours (11-12 days) at the higher doses. The volume of distribution to the second compartment $\left(\mathrm{V}_{2}\right)$ was high $(7,110-9,180 \mathrm{~mL} / \mathrm{kg})$, exceeding the estimated volume of aqueous body volume in rats $(668 \mathrm{~mL} / \mathrm{kg})$. The clearance increased and AUC per unit dose (dose-adjusted AUC) decreased with increasing dose. Bioavailability, calculated using both IV doses, exceeded $100 \%$ for most doses and decreased with increasing dose (Table D-9).
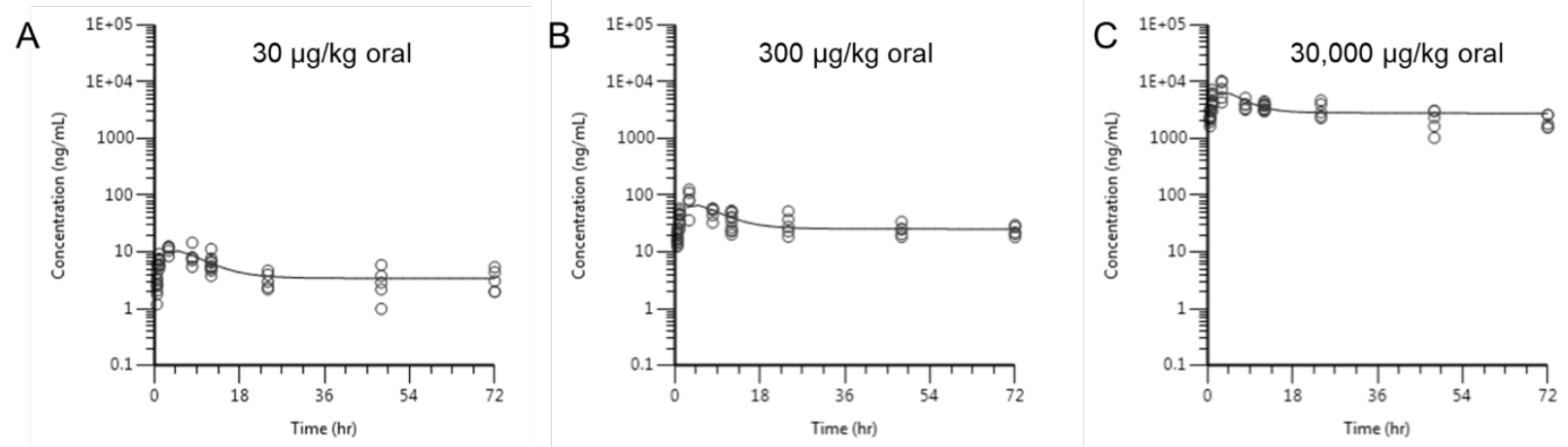

Figure D-2. Blood Concentrations versus Time Profiles of Hexachlorobenzene after a Single Gavage Administration of a 30 (A), 300 (B), or 30,000 (C) $\mu \mathrm{g} / \mathrm{kg}$ Dose in Female Rats

Two-compartmental model with first order input, first order output, and $1 / \mathrm{y}^{2}$ weighting was used to fit the data (shown as solid line).

Table D-8. Plasma Toxicokinetic Parameters of Hexachlorobenzene Following Single Gavage Administration in Female Rats ${ }^{\mathrm{a}}$

\begin{tabular}{|c|c|c|c|}
\hline \multirow{2}{*}{ Parameter $^{\mathbf{b}}$} & \multicolumn{3}{|c|}{ Dose } \\
\hline & $30 \mu \mathrm{g} / \mathrm{kg}$ & $300 \mu \mathrm{g} / \mathrm{kg}$ & $30,000 \mu \mathrm{g} / \mathrm{kg}$ \\
\hline $\mathrm{C}_{\max }(\mathrm{ng} / \mathrm{mL})$ & $10.6(1.1)$ & $67.5(7.8)$ & $6,630(750)$ \\
\hline $\mathrm{C}_{\max } / \operatorname{Dose}(\mathrm{ng} / \mathrm{mL} / \mu \mathrm{g} / \mathrm{kg})$ & $0.35(0.04)$ & $0.23(0.03)$ & $0.22(0.03)$ \\
\hline $\mathrm{T}_{\max }(\mathrm{hr})$ & $4.23(0.38)$ & $4.11(0.37)$ & $3.18(0.34)$ \\
\hline Alpha Half-life (hr) & $3.30(3.21)$ & $2.86(4.34)$ & $2.46(1.93)$ \\
\hline Beta Half-life (hr) & $3,340(1060)$ & $1,560(210)$ & $1,190(120)$ \\
\hline $\mathrm{K}_{10}(1 / \mathrm{hr})$ & $0.00124(0.0012)$ & $0.00235(0.0033)$ & $0.00244(0.0017)$ \\
\hline $\mathrm{K}_{10}$ Half-life (hr) & $559(526)$ & $295(414)$ & $284(202)$ \\
\hline $\mathrm{K}_{12}$ & $0.174(0.198)$ & $0.194(0.357)$ & $0.212(0.212)$ \\
\hline $\mathrm{K}_{21}$ & $0.0351(0.0068)$ & $0.0459(0.0095)$ & $0.067(0.0132)$ \\
\hline $\mathrm{CL}_{1} \_\mathrm{F}(\mathrm{mL} / \mathrm{hr} / \mathrm{kg})$ & $1.78(0.5)$ & $5.1(0.55)$ & $6.06(0.44)$ \\
\hline $\mathrm{CL}_{2} \_\mathrm{F}(\mathrm{mL} / \mathrm{hr} / \mathrm{kg})$ & $250(75)$ & $421(195)$ & $527(170)$ \\
\hline $\mathrm{V}_{1} \_\mathrm{F}(\mathrm{mL} / \mathrm{kg})$ & $1,440(1,240)$ & $2,170(3,020)$ & $2,480(1,750)$ \\
\hline $\mathrm{V}_{2} \_\mathrm{F}(\mathrm{mL} / \mathrm{kg})$ & $7,110(1,230)$ & $9,180(2,930)$ & $7,860(1,710)$ \\
\hline
\end{tabular}




\begin{tabular}{lccc}
\hline \multirow{2}{*}{ Parameter $^{\mathbf{b}}$} & \multicolumn{3}{c}{ Dose } \\
\cline { 2 - 4 } & $\mathbf{3 0} \boldsymbol{\mu \mathbf { g } / \mathbf { k g }}$ & $\mathbf{3 0 0} \boldsymbol{\mu \mathbf { g } / \mathbf { k g }}$ & $\mathbf{3 0 , 0 0 0} \boldsymbol{\mu g} / \mathbf{k g}$ \\
\hline AUC $\left(\mathrm{hr} \mathbf{n g}^{*} \mathrm{mgL}\right)$ & $16,800(4,700)$ & $58,800(6,300)$ & $4,950,000(360,000)$ \\
$\mathrm{AUC} / \mathrm{Dose}^{\mathrm{c}}(\mathrm{hr} * \mathrm{ng} / \mathrm{mL} / \mu \mathrm{g} / \mathrm{kg})$ & $560(157)$ & $196(21)$ & $165(12)$ \\
\hline
\end{tabular}

${ }^{\mathrm{a} B a s e d}$ on two-compartment model with first order absorption and elimination.

${ }^{b}$ Data are presented as mean (standard error).

${ }^{\mathrm{c}}$ Dose-adjusted area under the tissue concentration-time curve.

Table D-9. Bioavailability of Hexachlorobenzene Following Single Gavage Administration in Female Rats

\begin{tabular}{ccc}
\hline Gavage Dose & $\begin{array}{c}\text { Bioavailability (\%) Calculated } \\
\text { Using } \mathbf{1 0 0} \boldsymbol{\mu g} / \mathbf{k g} \text { IV Data }\end{array}$ & $\begin{array}{c}\text { Bioavailability (\%) Calculated } \\
\text { Using 1,000 } \boldsymbol{\mu g} / \mathbf{k g} \text { IV Data }\end{array}$ \\
\hline $30 \mu \mathrm{g} / \mathrm{kg}$ & 430 & 321 \\
$300 \mu \mathrm{g} / \mathrm{kg}$ & 151 & 113 \\
$30,000 \mu \mathrm{g} / \mathrm{kg}$ & 127 & 95 \\
\hline
\end{tabular}

$\mathrm{IV}=$ intravenous.

\section{D.3.3. Tissue Toxicokinetics of Hexachlorobenzene}

Tissues were collected as early as 2 hours and up to 84 days postadministration (Table D-2). Concentrations of HCB in tissue over time are shown in Figure D-3 and Figure D-4. Kinetic parameters of HCB in tissues were estimated using NCA (Table D-10). Kinetic parameters in the tissues were similar across routes of administration; only data from gavage administration, the more relevant route of administration, will be discussed. Adipose had the highest $\mathrm{C}_{\max }$ while lung had the lowest. In adipose tissue, the time to reach maximum concentration $\left(\mathrm{T}_{\max }\right)$ ranged from 24-72 hours and the increase in $\mathrm{C}_{\max }$ was generally proportional to dose. The $\lambda$ half-life of $\mathrm{HCB}$ in adipose ranged from $47-157$ days. In the liver, the $\mathrm{C}_{\max }$ was reached at 3 hours and increased proportionally with dose. The $\lambda$ half-life of HCB in the liver was $41-85$ days. In the lung, the $\mathrm{T}_{\max }$ ranged from $2-8$ hours. The $\mathrm{C}_{\max }$ was generally dose-proportional and the $\lambda$ half-life ranged from 32-122 days. For all tissues, the dose-adjusted AUC tended to decrease with increasing dose; this decrease was greatest in the adipose tissue. Adipose:blood AUC ratios were consistently high in all dose groups, ranging from 42.2 to 56.8 (Table D-11). In the liver and lung, the ratios were generally at or above 1 but did not exceed 4 . 
Hexachlorobenzene, NTP TOX 77
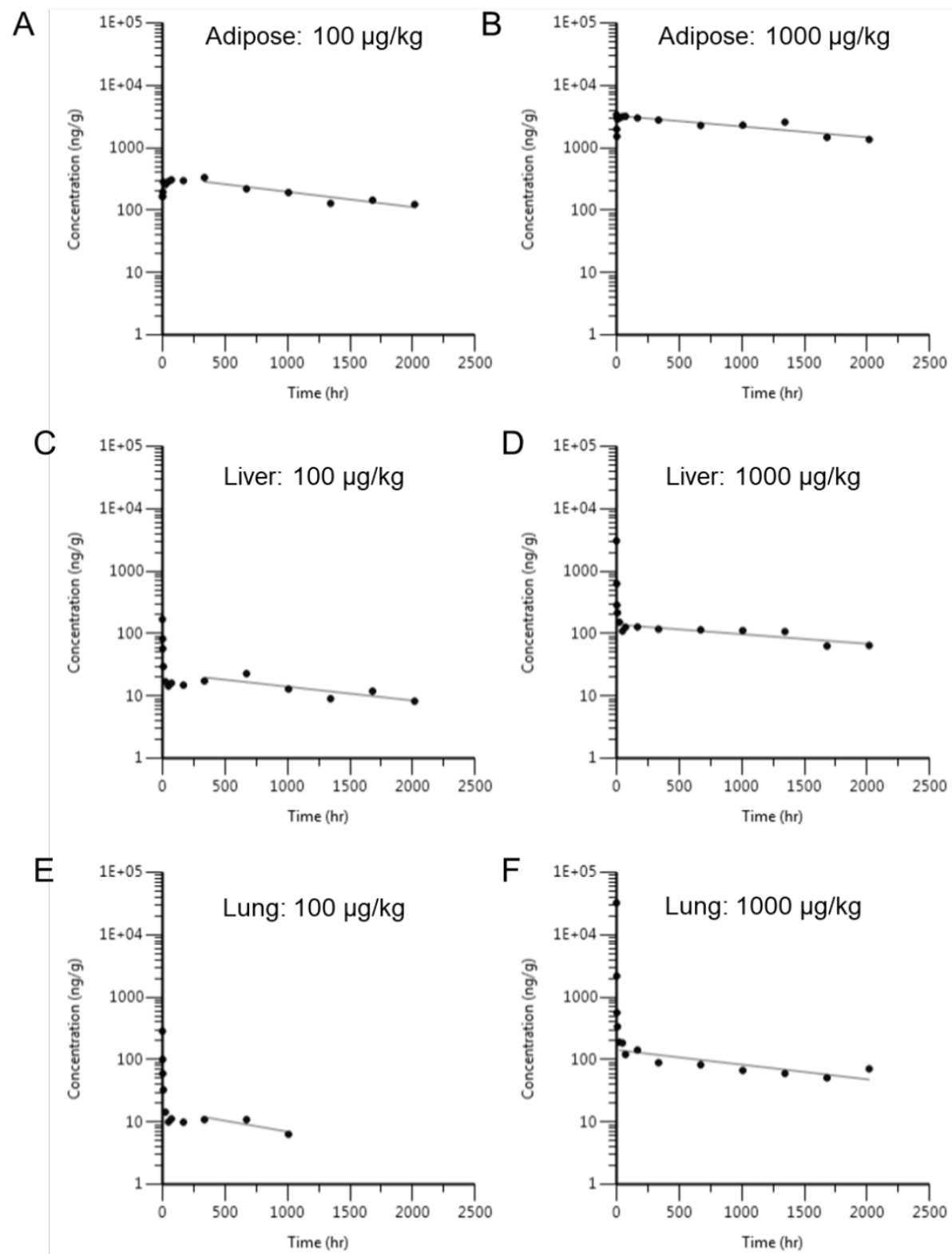

Figure D-3. Concentrations of Hexachlorobenzene Over Time in Adipose Tissue (A-B), Liver (C$D$ ), and Lung (E-F) after a Single Intravenous Administration of a 100 or $1,000 \mu \mathrm{g} / \mathrm{kg}$ Dose in Female Rats

Noncompartmental analysis was used to evaluate these data. 
Hexachlorobenzene, NTP TOX 77
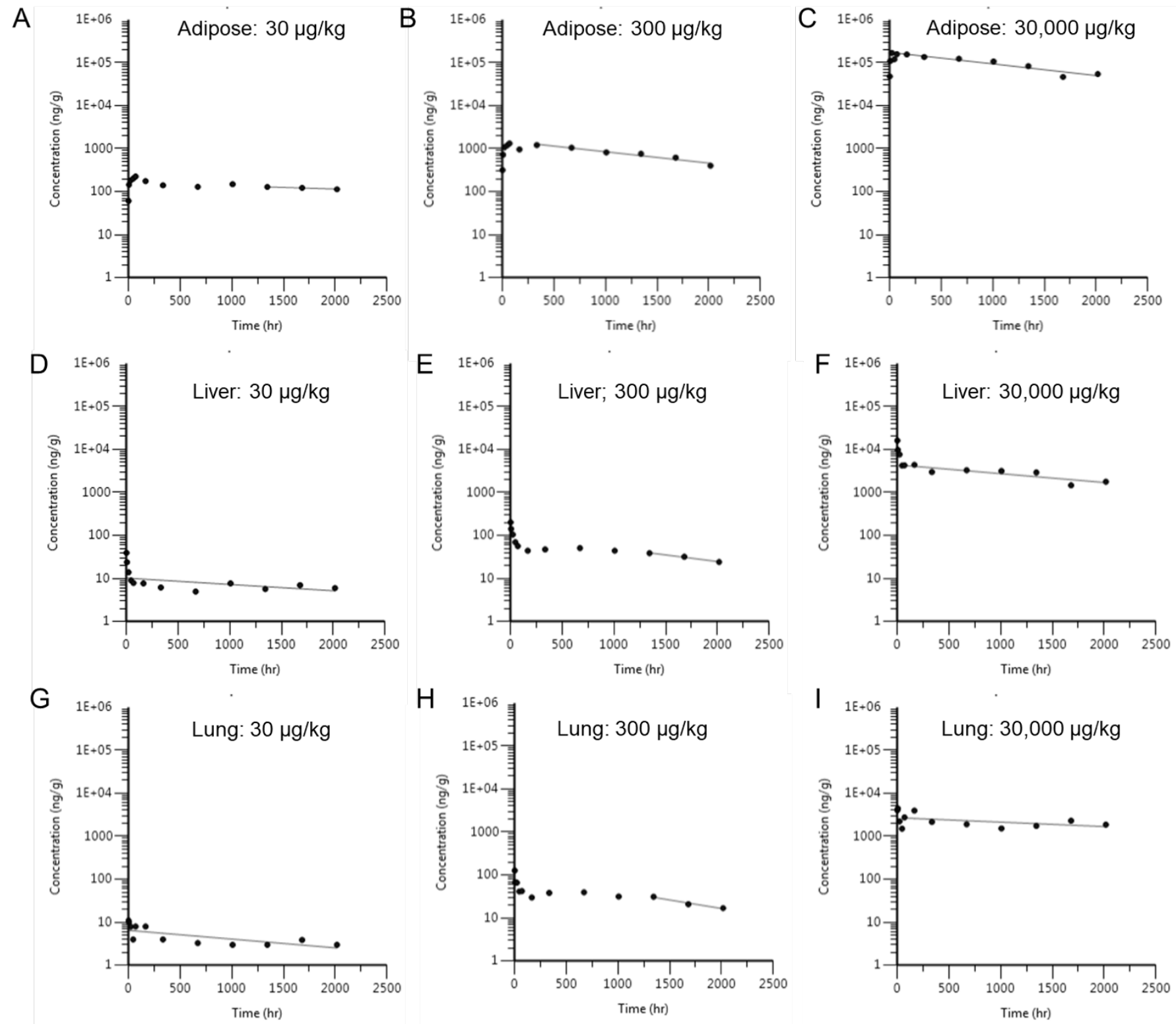

Figure D-4. Concentrations of Hexachlorobenzene Over Time in Adipose Tissue (A-C), Liver (DF), and Lung (G-I) after a Single Gavage Administration of a 30, 300, or 30,000 $\mu \mathrm{g} / \mathrm{kg}$ Dose in Female Rats

Noncompartmental analysis (solid line) was used to evaluate these data. 
Table D-10. Toxicokinetic Parameters of Hexachlorobenzene in Tissues Following Single Administration in Female Rats ${ }^{\mathrm{a}}$

\begin{tabular}{|c|c|c|c|c|c|c|c|c|}
\hline Tissue & $\begin{array}{c}\text { Route of } \\
\text { Administration }\end{array}$ & Dose $(\mu \mathrm{g} / \mathrm{kg})$ & $C_{\max }(\mathrm{ng} / \mathrm{g})$ & $\begin{array}{c}C_{\max } / \text { Dose } \\
(n g / \mathbf{m L} / \mu \mathrm{hg} / \mathrm{kg})\end{array}$ & $\mathbf{T}_{\max }(\mathbf{h r})$ & $\begin{array}{c}\lambda \text { Half-life } \\
(\mathrm{hr})\end{array}$ & $\operatorname{AUC}\left(h r^{*} n g / g\right)$ & $\begin{array}{c}\mathrm{AUC} / D o s \mathrm{D}^{\mathrm{b}} \\
(\mathrm{hr} * \mathrm{ng} / \mathrm{g}) / \mu \mathrm{g} / \mathrm{kg})\end{array}$ \\
\hline \multirow[t]{5}{*}{ Adipose } & IV & 100 & 334 & 3.34 & 336 & 1,230 & 608,000 & 6,080 \\
\hline & & 1,000 & 3,180 & 3.18 & 72 & 1,740 & $8,270,000$ & 8,270 \\
\hline & Oral & 30 & 226 & 7.53 & 72 & 3,770 & 903,000 & 30,100 \\
\hline & & 300 & 1,320 & 4.40 & 72 & 1,140 & $2,480,000$ & 8,267 \\
\hline & & 30,000 & 168,000 & 5.60 & 24 & 1,120 & $281,000,000$ & 9,367 \\
\hline \multirow[t]{5}{*}{ Liver } & IV & 100 & 82.4 & 0.82 & 2 & 1,350 & 45,800 & 458 \\
\hline & & 1,000 & 630 & 0.63 & 2 & 1,950 & 404,000 & 404 \\
\hline & Oral & 30 & 39.6 & 1.32 & 3 & 2,050 & 28,800 & 960 \\
\hline & & 300 & 202 & 0.67 & 3 & 981 & 122,000 & 407 \\
\hline & & 30,000 & 16,100 & 0.54 & 3 & 1,470 & $9,550,000$ & 318 \\
\hline \multirow[t]{5}{*}{ Lung } & IV & 100 & 101 & 1.01 & 2 & 860 & 19,700 & 197 \\
\hline & & 1,000 & 2,180 & 2.18 & 2 & 1,280 & 287,000 & 287 \\
\hline & Oral & 30 & 11 & 0.37 & 3 & 1,480 & 13,300 & 443 \\
\hline & & 300 & 127 & 0.42 & 3 & 763 & 82,200 & 274 \\
\hline & & 30,000 & 4,420 & 0.15 & 8 & 2,930 & $11,300,000$ & 377 \\
\hline
\end{tabular}

$\mathrm{C}_{\max }=$ maximum concentration; $\mathrm{T}_{\max }=$ time to maximum concentration; $\mathrm{AUC}=$ area under the curve; $\mathrm{IV}=$ intravenous.

aBased on noncompartmental analysis.

bose-normalized area under the tissue concentration-time curve. 
Table D-11. Ratio of Tissue and Blood Mean Area under the Curve

\begin{tabular}{lccc}
\hline \multicolumn{1}{c}{ Tissue } & Route of Administration & Dose $(\boldsymbol{\mu g} / \mathbf{k g})$ & Ratio \\
\hline Adipose & IV & 100 & 46.8 \\
& & 1,000 & 47.5 \\
& Oral & 30 & 53.8 \\
& & 300 & 42.2 \\
& & 30,000 & 56.8 \\
\hline \multirow{2}{*}{ Liver } & IV & 100 & 3.5 \\
& & 1,000 & 2.3 \\
& Oral & 30 & 1.7 \\
& & 300 & 2.1 \\
& & 30,000 & 1.9 \\
\hline \multirow{2}{*}{ Lung } & IV & 100 & 1.5 \\
& & 1,000 & 1.6 \\
& Oral & 30 & 0.8 \\
& & 300 & 1.4 \\
& & 30,000 & 2.3 \\
\hline
\end{tabular}

$\mathrm{IV}=$ intravenous.

\section{D.4. Summary}

Numerous studies in humans and in various animal models have yielded a great understanding of HCB absorption, distribution, metabolism, and elimination. However, estimates of half-life, particularly in female rats, have not been adequately reported. This study was designed to generate data to determine the toxicokinetic parameters of HCB in female Sprague Dawley rats to complement the toxic equivalency factor studies.

Overall, results from this study corroborate the existing literature about the absorption and distribution of HCB. Orally administered HCB was rapidly absorbed and distributed to the mesenteric adipose tissue, liver, and lung. Blood $\mathrm{C}_{\max }$ increased proportionally with dose, though the AUC appeared to have nonlinear kinetics, as the dose-adjusted AUC was reduced at the two highest doses. Measurement of HCB and its metabolites in urine, feces, and tissues would help determine if the primary driver of these changes is metabolism or elimination. The half-lives observed in rats were shorter than estimated half-lives in humans. Bioavailability of HCB exceeded 100\% at most doses. Given its lipophilicity, HCB administered IV may not be as efficiently absorbed by tissues and thus excreted faster, resulting in lower tissue accumulation and lower systemic exposure leading to bioavailability values exceeding $100 \%$. Interestingly, bioavailability decreases at the higher oral doses of HCB suggesting some saturation of absorption or elimination processes. 


\section{Appendix E. Genetic Toxicology}

\section{Table of Contents}

E.1. Bacterial Mutagenicity Test Protocol ..............................................................................2

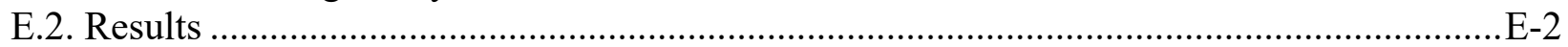

Tables

Table E-1. Mutagenicity of Hexachlorobenzene in Salmonella typhimurium ............................E-2 


\section{E.1. Bacterial Mutagenicity Test Protocol}

Testing was performed as reported by Haworth et al. ${ }^{93}$ Hexachlorobenzene (HCB) was sent to the laboratory as a coded aliquot from Radian Corporation (Austin, TX). It was incubated with the Salmonella typhimurium tester strains TA98, TA100, TA1535, and TA1537, in either buffer or S9 mix (metabolic activation enzymes and cofactors from Aroclor 1254-induced male Sprague Dawley rat or Syrian hamster liver) for 20 minutes at $37^{\circ} \mathrm{C}$. Top agar supplemented with $L$-histidine and $d$-biotin was added, and the contents of the tubes were mixed and poured onto the surfaces of minimal glucose agar plates. Histidine-independent mutant colonies arising on these plates were counted after 2 days of incubation at $37^{\circ} \mathrm{C}$.

Each trial consisted of triplicate plates of concurrent positive and negative controls and of five doses of HCB. In the absence of toxicity, the high dose was limited by experimental design to $10,000 \mu \mathrm{g} / \mathrm{plate}$. All trials were repeated.

In this assay, a positive response is defined as a reproducible, dose-related increase in histidine-independent (revertant) colonies in any one strain/activation combination. An equivocal response is defined as an increase in revertants that is not dose related, reproducible, or of sufficient magnitude to support a determination of mutagenicity. A negative response is obtained when no increase in revertant colonies is observed following chemical treatment. No minimum percentage or fold-increase is required for a chemical to be judged positive or weakly positive.

\section{E.2. Results}

HCB (100 to $10,000 \mu \mathrm{g} /$ plate) was not mutagenic in S. typhimurium strains TA98, TA100, TA1535, or TA1537 with or without rat or hamster liver S9 activation enzymes (Table E-1).

Table E-1. Mutagenicity of Hexachlorobenzene in Salmonella typhimurium ${ }^{\mathrm{a}}$

\begin{tabular}{lccccccc}
\hline \multicolumn{1}{c}{ Strain } & $\begin{array}{c}\text { Dose } \\
(\boldsymbol{\mu} \text { g/plate })\end{array}$ & Without S9 & Without S9 & $\begin{array}{c}\text { With 10\% } \\
\text { Hamster S9 }\end{array}$ & $\begin{array}{c}\text { With 10\% } \\
\text { Hamster S9 }\end{array}$ & $\begin{array}{c}\text { With 10\% } \\
\text { Rat S9 }\end{array}$ & $\begin{array}{c}\text { With 10\% } \\
\text { Rat S9 }\end{array}$ \\
\hline TA100 & & & & & & & \\
& 0 & $81 \pm 8$ & $91 \pm 3$ & $96 \pm 10$ & $93 \pm 6$ & $107 \pm 3$ & $88 \pm 7$ \\
& 100 & $88 \pm 6$ & $86 \pm 7$ & $92 \pm 5$ & $107 \pm 4$ & $113 \pm 6$ & $101 \pm 13$ \\
& 333.3 & $83 \pm 5$ & $86 \pm 4$ & $92 \pm 4$ & $90 \pm 5$ & $93 \pm 5$ & $87 \pm 7$ \\
& 1,000 & $63 \pm 7^{\mathrm{b}}$ & $68 \pm 4^{\mathrm{b}}$ & $82 \pm 5^{\mathrm{b}}$ & $105 \pm 3$ & $83 \pm 5^{\mathrm{b}}$ & $77 \pm 7^{\mathrm{b}}$ \\
& 3,333 & $75 \pm 7^{\mathrm{b}}$ & $88 \pm 6^{\mathrm{b}}$ & $86 \pm 8^{\mathrm{b}}$ & $93 \pm 4$ & $103 \pm 12^{\mathrm{b}}$ & $97 \pm 9^{\mathrm{b}}$ \\
& 10,000 & $72 \pm 8^{\mathrm{b}}$ & $87 \pm 8^{\mathrm{b}}$ & $87 \pm 2^{\mathrm{b}}$ & $97 \pm 2$ & $92 \pm 2^{\mathrm{b}}$ & $99 \pm 2^{\mathrm{b}}$ \\
& & Negative & Negative & Negative & Negative & Negative & Negative \\
Trial Summary & & $376 \pm 18$ & $500 \pm 11$ & $1,238 \pm 91$ & $290 \pm 21$ & $826 \pm 36$ & $1,066 \pm 12$ \\
\hline Positive Control & & & & & & &
\end{tabular}




\begin{tabular}{|c|c|c|c|c|c|c|c|}
\hline Strain & $\begin{array}{c}\text { Dose } \\
(\mu \mathrm{g} / \mathrm{plate})\end{array}$ & Without S9 & Without S9 & $\begin{array}{c}\text { With } 10 \% \\
\text { Hamster S9 }\end{array}$ & $\begin{array}{c}\text { With } 10 \% \\
\text { Hamster S9 }\end{array}$ & $\begin{array}{c}\text { With } 10 \% \\
\text { Rat S9 }\end{array}$ & $\begin{array}{c}\text { With } 10 \% \\
\text { Rat S9 }\end{array}$ \\
\hline \multicolumn{8}{|l|}{ TA1535 } \\
\hline & 0 & $18 \pm 4$ & $8 \pm 1$ & $9 \pm 1$ & $12 \pm 3$ & $11 \pm 3$ & $5 \pm 2$ \\
\hline & 100 & $22 \pm 3$ & $10 \pm 1$ & $7 \pm 2$ & $5 \pm 1$ & $8 \pm 0$ & $6 \pm 1$ \\
\hline & 333.3 & $15 \pm 1$ & $9 \pm 1$ & $5 \pm 1$ & $6 \pm 3$ & $10 \pm 2$ & $6 \pm 1$ \\
\hline & 1,000 & $20 \pm 1^{\mathrm{b}}$ & $12 \pm 2^{b}$ & $9 \pm 1^{b}$ & $8 \pm 3^{b}$ & $9 \pm 3^{b}$ & $4 \pm 1^{b}$ \\
\hline & 3,333 & $17 \pm 4^{\mathrm{b}}$ & $9 \pm 1^{\mathrm{b}}$ & $13 \pm 3^{b}$ & $8 \pm 1^{b}$ & $9 \pm 2^{\mathrm{b}}$ & $8 \pm 1^{\mathrm{b}}$ \\
\hline & 10,000 & $13 \pm 2^{\mathrm{b}}$ & $11 \pm 3^{b}$ & $10 \pm 1^{\mathrm{b}}$ & $7 \pm 2^{\mathrm{b}}$ & $9 \pm 0^{\mathrm{b}}$ & $5 \pm 1^{\mathrm{b}}$ \\
\hline Trial Summary & & Negative & Negative & Negative & Negative & Negative & Negative \\
\hline Positive Control ${ }^{\mathrm{c}}$ & & $300 \pm 21$ & $337 \pm 23$ & $326 \pm 21$ & $186 \pm 13$ & $355 \pm 11$ & $387 \pm 26$ \\
\hline \multicolumn{8}{|l|}{ TA1537 } \\
\hline & 0 & $6 \pm 1$ & $6 \pm 0$ & $10 \pm 2$ & $5 \pm 1$ & $15 \pm 0$ & $6 \pm 1$ \\
\hline & 100 & $7 \pm 2$ & $8 \pm 2$ & $16 \pm 3$ & $9 \pm 2$ & $21 \pm 2$ & $7 \pm 1$ \\
\hline & 333.3 & $12 \pm 2$ & $4 \pm 0$ & $16 \pm 3$ & $10 \pm 3$ & $17 \pm 2$ & $7 \pm 1$ \\
\hline & 1,000 & $8 \pm 1^{\mathrm{b}}$ & $6 \pm 2^{b}$ & $23 \pm 4^{b}$ & $10 \pm 2^{b}$ & $22 \pm 5^{\mathrm{b}}$ & $8 \pm 1^{\mathrm{b}}$ \\
\hline & 3,333 & $10 \pm 2^{b}$ & $5 \pm 2^{b}$ & $15 \pm 3^{b}$ & $8 \pm 1^{\mathrm{b}}$ & $21 \pm 2^{\mathrm{b}}$ & $9 \pm 1^{b}$ \\
\hline & 10,000 & $11 \pm 1^{\mathrm{b}}$ & $7 \pm 2^{\mathrm{b}}$ & $15 \pm 0^{\mathrm{b}}$ & $9 \pm 1^{\mathrm{b}}$ & $18 \pm 2^{b}$ & $7 \pm 1^{\mathrm{b}}$ \\
\hline Trial Summary & & Negative & Negative & Negative & Negative & Negative & Negative \\
\hline Positive Control $^{\mathrm{c}}$ & & $245 \pm 43$ & $258 \pm 17$ & $487 \pm 35$ & $362 \pm 20$ & $297 \pm 29$ & $461 \pm 16$ \\
\hline \multicolumn{8}{|l|}{ TA98 } \\
\hline & 0 & $19 \pm 1$ & $14 \pm 3$ & $29 \pm 2$ & $22 \pm 2$ & $41 \pm 2$ & $22 \pm 3$ \\
\hline & 100 & $23 \pm 4$ & $15 \pm 2$ & $34 \pm 3$ & $22 \pm 1$ & $41 \pm 1$ & $26 \pm 2$ \\
\hline & 333.3 & $23 \pm 1$ & $15 \pm 1$ & $32 \pm 7$ & $20 \pm 2$ & $35 \pm 3$ & $25 \pm 2$ \\
\hline & 1,000 & $19 \pm 1^{\mathrm{b}}$ & $15 \pm 2^{b}$ & $34 \pm 3^{b}$ & $24 \pm 3^{b}$ & $41 \pm 4^{\mathrm{b}}$ & $23 \pm 4^{b}$ \\
\hline & 3,333 & $20 \pm 4^{b}$ & $16 \pm 0^{\mathrm{b}}$ & $36 \pm 4^{\mathrm{b}}$ & $16 \pm 1^{\mathrm{b}}$ & $30 \pm 1^{\mathrm{b}}$ & $23 \pm 1^{b}$ \\
\hline & 10,000 & $23 \pm 2^{b}$ & $21 \pm 2^{\mathrm{b}}$ & $38 \pm 1^{b}$ & $19 \pm 4^{\mathrm{b}}$ & $37 \pm 2^{b}$ & $19 \pm 2^{b}$ \\
\hline Trial Summary & & Negative & Negative & Negative & Negative & Negative & Negative \\
\hline Positive Control $^{\mathrm{c}}$ & & $655 \pm 70$ & $693 \pm 39$ & $198 \pm 10$ & $199 \pm 8$ & $542 \pm 13$ & $787 \pm 53$ \\
\hline
\end{tabular}




\section{Appendix F. Supplemental Data}

Tables with supplemental data can be found here: https://doi.org/10.22427/NTP-DATA-TOX77.

\section{F.1. Short-Term}

\section{F.1.1. Three-Month Study Tables - Rats}

E03 - Initial and Current Body Weights

9800401_E03_Initial_And_Current_Body_Weight.pdf

E40 - Growth Curves

9800401_E40_Growth_Curve.pdf

E41 - Mean Body Weights and Survival Table

9800401_E41_Mean_Body_Weights_and_Survival_Table.pdf

P03 - Incidence Rates of Non-Neoplastic Lesions by Anatomic Site

9800401_P03_Incidence_Rates_of_Non-Neoplastic_Lesions_by_Anatomic_Site.pdf

P04 - Neoplasms by Individual Animal

9800401_P04_Neoplasms_by_Individual_Animal.pdf

P05 - Incidence Rates of Neoplasms by Anatomic Sites (Systemic Lesions Abridged)

9800401_P05_Incidence_Rates_of_Neoplasms_by_Anatomic_Sites_(Systemic_Lesions_Abridg ed).pdf

P09 - Non-Neoplastic Lesions by Individual Animal

9800401_P09_Non-Neoplastic_Lesions_by_Individual_Animal.pdf

P10 - Statistical Analysis of Non-Neoplastic Lesions

9800401_P10_Statistical_Analysis_of_Non-Neoplastic_Lesions.pdf

\section{P14 - Individual Animal Pathology Data}

9800401_P14_Individual_Animal_Pathology_Data.pdf

P18 - Incidence Rates of Non-Neoplastic Lesions by Anatomic Site with Average Severity Grades

9800401_P18_Incidence_Rates_of_Non-

Neoplastic_Lesions_by_Ānatomic_Site_with_Average_Severity_Grades.pdf

P40 - Survival Curves

9800401_P40_Survival_Curves.pdf

PA06 - Organ Weights Summary

9800401_PA06_Organ_Weights_Summary.pdf

PA45 - Hepatic Cell Proliferation Data

9800401_PA45_Hepatic_Cell_Proliferation_Data.pdf 
PA48 - Summary of Tissue Concentration 9800401_PA48_Summary_of_Tissue_Concentration.pdf

PA49 - Summary of Cytochrome Activity 9800401_PA49_Summary_of_Cytochrome_Activity.pdf

R07 - Hormone Summary

9800401_R07_Hormone_Summary.pdf

\section{F.1.2. Three-Month Individual Animal Data - Rats}

Female Individual Animal Body Weight Data

9800401_Female_Individual_Animal_Body_Weight_Data.xls

Female Individual Animal Clinical Observations

9800401_Female_Individual_Animal_Clinical_Observations.xls

Female Individual Animal Neoplastic Pathology Data

9800401_Female_Individual_Animal_Neoplastic_Pathology_Data.xls

Female Individual Animal Non-Neoplastic Pathology Data

9800401_Female_Individual_Animal_Non_Neoplastic_Pathology_Data.xls

Female Individual Animal Survival Data

9800401_Female_Individual_Animal_Survival_Data.xls

Individual Animal Cytochrome Activity Data

9800401_Individual_Animal_Cytochrome_Activity_Data.xlsx

Individual Animal Hormone Data

9800401_Individual_Animal_Hormone_Data.xlsx

Individual Animal Liver Special Studies Data

9800401_Individual_Animal_Liver_Special_Studies_Data.xlsx

Individual Animal Organ Weight Data

9800401_Individual_Animal_Organ_Weight_Data.xlsx

Individual Animal Tissue Concentration Data

9800401_Individual_Animal_Tissue_Concentration_Data.xlsx

\section{F.2. Toxicokinetics}

\section{F.2.1. TK Parameter Data}

TK Hexachlorobenzene S0654 S0811 Remodeled IV Gav Rat Female S0654_S0811_TK_Hexachlorobenzene_S0654_S0811_Remodeled_IV_Gav_Rat_Female_508 (002).pdf 


\section{F.2.2. Individual Animal Data}

TKS Hexachlorobenzene 2001 S0654 Individual Animal Data

S0654_TKS_Hexachlorobenzene_2001_S0654 Individual Animal Data.xlsx

TKS Hexachlorobenzene 2003 S0811 Individual Animal Data

S0811_TKS_Hexachlorobenzene_2003_S0811 individual animal data.xlsx 


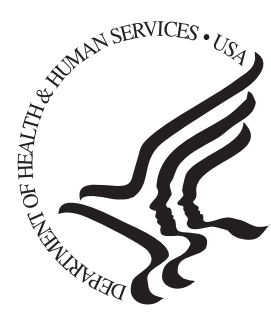

\section{National Toxicology Program}

\section{NTP Central Data Management, MD EC-03}

National Institute of Environmental Health Sciences

P.O. Box 12233

Research Triangle Park, NC 27709

http://ntp.niehs.nih.gov 